\title{
The Impact of Tree Species, Elevated Nitrogen Deposition, Stand Age, and Environmental Factors on Herbaceous Plant Communities in a Central Appalachian Hardwood Forest
}

\author{
Lacey J. Smith \\ West Virginia University, ljsmith1@mix.wvu.edu
}

Follow this and additional works at: https://researchrepository.wvu.edu/etd

Part of the Biodiversity Commons, Forest Biology Commons, Forest Management Commons, and the Other Plant Sciences Commons

\section{Recommended Citation}

Smith, Lacey J., "The Impact of Tree Species, Elevated Nitrogen Deposition, Stand Age, and Environmental Factors on Herbaceous Plant Communities in a Central Appalachian Hardwood Forest" (2019). Graduate Theses, Dissertations, and Problem Reports. 4014.

https://researchrepository.wvu.edu/etd/4014

This Thesis is protected by copyright and/or related rights. It has been brought to you by the The Research Repository @ WVU with permission from the rights-holder(s). You are free to use this Thesis in any way that is permitted by the copyright and related rights legislation that applies to your use. For other uses you must obtain permission from the rights-holder(s) directly, unless additional rights are indicated by a Creative Commons license in the record and/ or on the work itself. This Thesis has been accepted for inclusion in WVU Graduate Theses, Dissertations, and Problem Reports collection by an authorized administrator of The Research Repository @ WVU. For more information, please contact researchrepository@mail.wvu.edu. 
The Impact of Tree Species, Elevated Nitrogen Deposition, Stand Age, and Environmental Factors on Herbaceous Plant Communities in a Central Appalachian Hardwood Forest

\author{
Lacey J. Smith \\ Thesis submitted to the \\ Davis College of Agriculture, Natural Resources, and Design \\ at West Virginia University \\ in partial fulfillment of the requirements for the degree of
}

Master of Science

in

Forestry

Kirsten Stephan, PhD, Chair

Mary Beth Adams, PhD

William Peterjohn, PhD

Division of Forestry

Morgantown, West Virginia

2019

Keywords: sugar maple, red maple, herbaceous layer, cover, species richness, diversity, evenness, nitrogen fertilization, Fernow Experimental Forest

Copyright @ 2019 Lacey J. Smith 


\begin{abstract}
The Impact of Tree Species, Elevated Nitrogen Deposition, Stand Age, and Environmental Factors on Herbaceous Plant Communities in a Central Appalachian Hardwood Forest
\end{abstract}

\title{
Lacey J. Smith
}

Although the herb layer represents less than $1 \%$ of the biomass of temperate forests, this layer may contain up to $90 \%$ of the plant species in the forest and can contribute up to $20 \%$ of the foliar litter, thus playing an essential role in forest biodiversity and nutrient cycling. The objectives of this study were to investigate the differences in cover, species richness, ShannonWiener diversity, and evenness of herb layer plants a) under tree species associated with contrasting soil nitrogen levels and $b$ ) in watersheds that vary in nitrogen deposition, stand age, and watershed aspect at the Fernow Experimental Forest in West Virginia. In the watersheds evaluated, overstory tree species, $\mathrm{N}$ deposition level, stand age, and other environmental factors influenced herb layer characteristics. This study demonstrated 1) a sugar maple effect, i.e. sugar maple having a positive effect on understory cover, at intermediate levels of soil fertility in reference watersheds and in an $\mathrm{N}$-fertilized watershed by improving the nutrient microenvironment for herb layer plants, 2) that long-term $\mathrm{N}$ enrichment can reduce ecosystem biodiversity by favoring nitrophilic species, and 3) that herb layer characteristics can be influenced by stand age, with more recent disturbance being reflected in higher herb layer abundance and diversity. This study justifies further examination of tree-herb layer interactions for a wider range of tree species, N-deposition levels, and stand ages in future studies in order to inform adaptive forest management in the light of climate change and other continuing anthropogenic influences. 


\section{Acknowledgements}

This work is supported by the USDA National Institute of Food and Agriculture, Mclntire Stennis Cooperative Research Program, project \# WVA00129, and the West Virginia Agricultural and Forestry Experiment Station.

I would like to thank my advisor, Dr. Kirsten Stephan, for her constant support, guidance, and encouragement throughout my Master's degree. When I first entered the program, I did not have a strong background in Forestry or strong writing skills. Dr. Stephan showed me how to sharpen my writing skills and to think like a scientist. I appreciate all of her support, as I could not have done it without her.

Thank you to my committee members, Dr. Mary Beth Adams and Dr. William Peterjohn for all their knowledge and expertise of the Fernow Experimental Forest and their continuing patience throughout this study. I would also like to thank Dr. Jonathan Cumming in the Biology Department for his expertise in soil and plant relations and Dr. Ida Holásková for her statistical expertise. I would also like to thank the Brzostek lab, Eddie, Joe, and Nanette, for encouraging me as an undergraduate to continue my education.

I would like to thank my family and friends for their encouragement throughout my education and providing the life skills needed for a successful career. Special thanks to Zachary Heck, for his constant love and support. Graduate school would have been a lot more difficult without you. I appreciate everyone that has helped me get to this point in my life, thank you. 
TABLE OF CONTENTS

ABSTRACT
ACKNOWLEDGEMENTS
LIST OF TABLES
LIST OF FIGURES

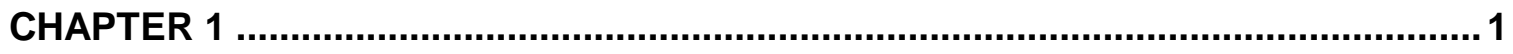

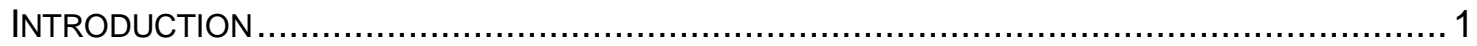

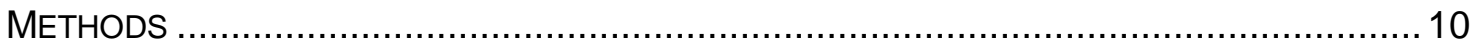

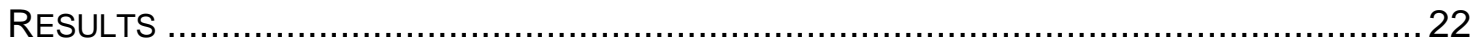

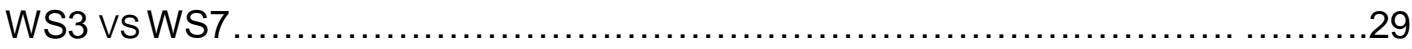

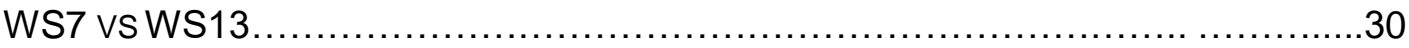

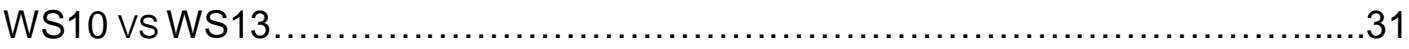

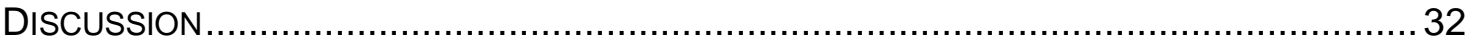

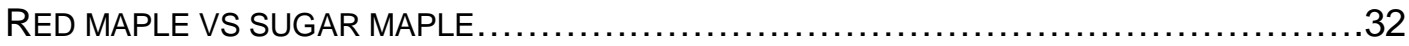

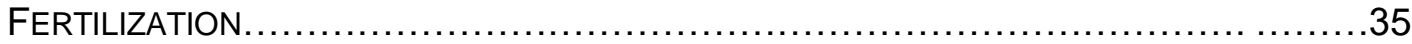

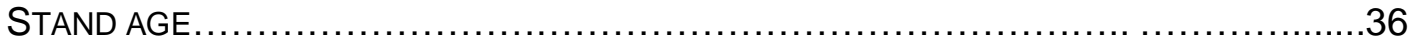

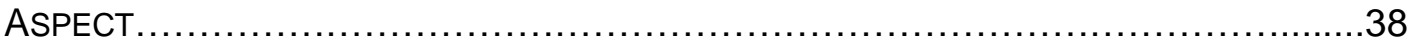

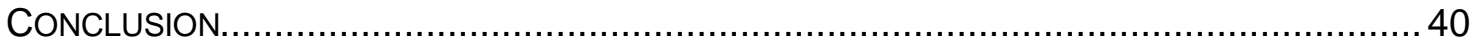

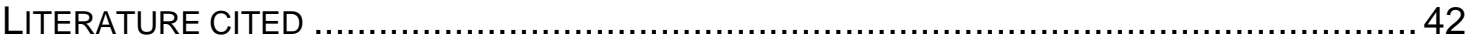

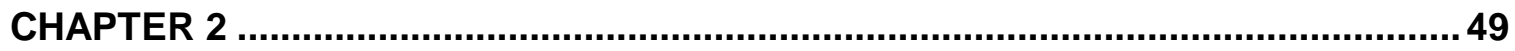

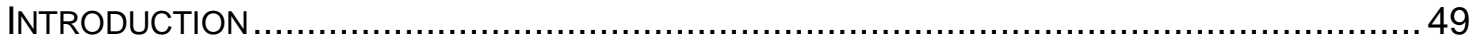

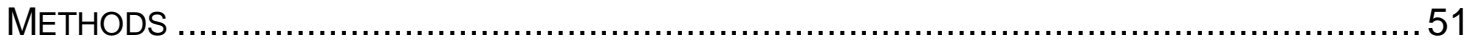

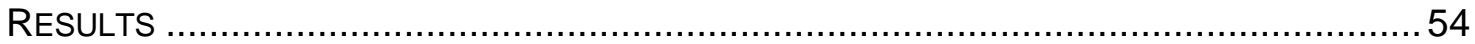

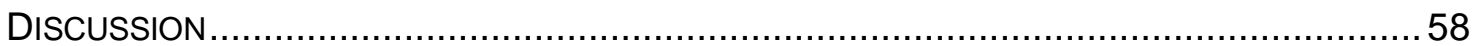

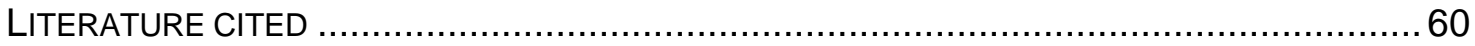

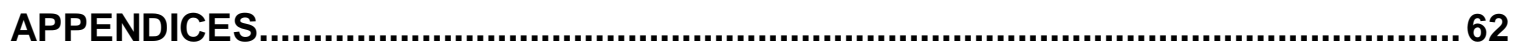

TABLE A1: LOCATION, ELEVATION, AND DBH OF TREE SPECIES IN THIS STUDY ................62

TABLE A2: THE FIVE CLOSEST NEIGHBORING ECTOMYCORRHIZAL AND ARBUSCULAR

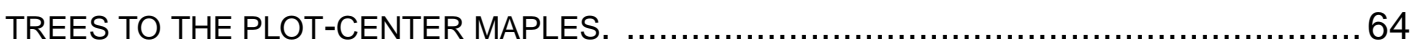

TABLE A3: TOTAL COVER OF ALL UNDERSTORY TAXA IN THIS STUDY IN EACH

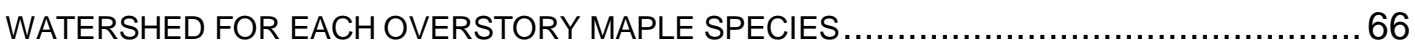

TABLE A4. ANOVA RESULTS TESTING THE EFFECT OF WATERSHED, OVERSTORY MAPLE SPECIES AND THEIR INTERACTION FOR 22 INDIVIDUAL HERB-LAYER SPECIES ....69

TABLE A5. DISTANCE BETWEEN PLOT CENTER MAPLES WITHIN A PLOT PAIR. .................. 74

TABLE A6. ANOVA TESTS OF EFFECT SLICES ................................................... 75

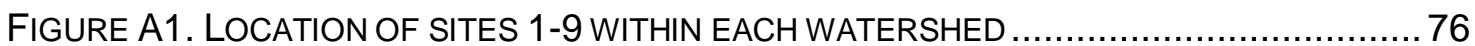




\section{List of Tables: Chapter 1}

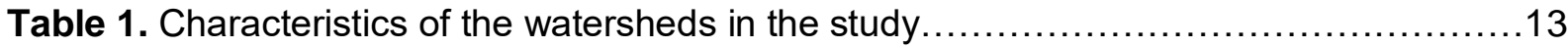

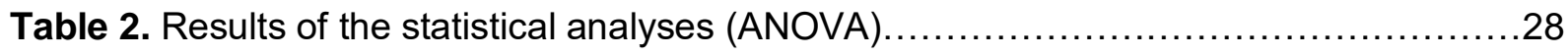

Table 3. Streamwater nutrient concentrations at the Fernow Experimental Forest ............37

\section{List of Tables: Chapter 2}

Table 1. Characteristics of the watersheds in the study.... .51

Table 2. Regression components for estimating aboveground biomass of 42 plant species and four functional groups using the linear equation 


\section{List of Figures: Chapter 1}

Figure 1. Location of Fernow Experimental Forest and watersheds used in this study

Figure 2. Slopes of the study watersheds (WS3, WS7, WS10, WS13) at the Fernow Experimental Forest.

Figure 3. Experimental design of plot pairs at each site for collecting herb composition and cover.

Figure 4. Visual illustration of the hand-area method.

Figure 5. Visual illustration of how the five closest neighboring trees were separated by ectomycorrhizal (ECM) or arbuscular mycorrhizal (AM) association....

Figure 6. Relative cover of 8 understory taxa and other

Figure 7. Mean cover per of the most common understory plant species in WS3, WS7, WS10, and WS13

Figure 8. Herb characteristics in red and sugar maple plots in each of the studied watersheds

Figure 9. Biotic and abiotic factors influencing study plots under red and sugar maples in each of the watersheds.

Figure 10. Conceptual diagram of how sugar and red maple may affect herb layer biomass.

\section{List of Figures: Chapter 2}

Figure 1. Visual illustration of the hand-area method.

Figure 2. Relationships of log-transformed cover and biomass for the dominant herb species per functional group

Figure 3. Linear regressions between aboveground biomass and cover 


\section{Chapter 1}

\section{Effects of Tree Species, Land Use History, and Environmental Factors on Herbaceous Plant Community Characteristics}

\section{Introduction}

Importance of the herb layer in forest ecosystems

The importance of the herbaceous layer in forest ecosystems has received increasing attention in recent decades (Gilliam 2014). While it represents less than $1 \%$ of the biomass of the forest, it contains between 75 and $91 \%$ of the plant species of the forest and can contribute up to $20 \%$ of the foliar litter mass to the forest floor (Gilliam 2007).

Biodiversity, defined as the variety of living organisms, is linked to ecosystem stability and productivity (Hooper et al. 2005). Biodiversity increases ecosystem productivity, nutrient use and retention, and ecosystem resilience (Tilman et al. 1997, Liang et al. 2015). According to the niche-efficiency model, a plant's individual rate of productivity is highest in a diverse system, and, conversely, the loss of biodiversity will decrease a plant's individual rate of productivity (Liang et al. 2015). Better utilization of nutrients in diverse communities can reduce the leaching of nutrients, including nitrogen and calcium, which will increase the sustainability of nutrient cycling and soil fertility at least in grassland ecosystems (Tilman et al. 1997). Greater plant biodiversity can also produce a greater mixture of root exudates, which can further create a more diverse soil microbial community (Lavelle et al. 1995, Broekling 2008, Fu et al. 2015), leading to a more resilient soil environment that is better protected against stress and disturbances (Brussaard et al. 2007). 
Litter decomposition is one of the major drivers of nutrient cycling and nutrient availability in an ecosystem (Freshet et al. 2013). Live leaves of typical herb layer species have high concentrations of $\mathrm{N}, \mathrm{P}, \mathrm{K}$, and $\mathrm{Mg}$ and low concentrations of lignin and cellulose. After senescence, the quality of leaf litter, measured as litter C:N ratio and carbon quality, correlates strongly with corresponding parameters in living leaves (Chapin 2003). The plant will reabsorb approximately half of their nitrogen and phosphorus pools and very little of the initial carbon pool, regardless of the environment in which they grow (Chapin and Kedrowski 1983, Aerts and Chapin 2000). Litter decomposability varies across plant species (Freschet et al. 2013) and, more broadly, between spring and summer herbs. Spring and summer herbs differ in their metabolic rates, which may be caused by differences in light and nutrient availability at their time of growth. During the summer months, nutrients are less available due to microbes and woody plants immobilizing large quantities, causing the summer herbs, living in the shade of the forest trees, to maintain low metabolic rates (Gilliam 2014, Taylor and Pearcy 1976). In contrast, spring ephemeral herbs, with their short period of growth and reproduction completed before the canopy closes (Lapointe 2001, Vezina and Grandtner 1965), have high rates of photosynthesis and respiration, requiring a high mineral nutrient supply. This led to the vernal dam hypothesis, stating that spring ephemerals can serve as a short-term nutrient sink, preventing nutrients from being leached into streams and, therefore, from being removed from the ecosystem (Muller and Bormann 1976). In addition, following the decomposition of senesced aboveground biomass, areas with more spring ephemerals may have higher soil nutrient concentrations than areas with fewer ephemerals (Muller 1978). In sum, spring and summer herb litter, with its low C:N ratio and high $\mathrm{C}$ quality, on average decomposes more than twice as rapidly as tree litter (Mueller 2003; Melillo et al. 1989), thus providing a rapid pathway for the recycling of nutrients and underscoring the importance of the herb layer despite its tiny biomass footprint in the forest (Elliott et al. 2015). 
Interactions between Trees and the Herb Layer

The forest overstory has a direct effect on the availability of resources for herb layer plants (Gilliam 2014). Most obviously, trees decrease the amount and quality of light reaching the forest floor. The overstory can also decrease nutrient and moisture availability via uptake by fine roots (Gilliam 2014) located in the O-horizon (i.e., below the litter, in the soil layer with the highest organic matter content) and via interception of precipitation and atmospheric deposition by foliage.

Stemflow, the portion of precipitation that runs down the tree trunk and branches, could be important in establishing soil moisture and mineral gradients around the tree base (Carlisle et al. 1967). Thus, stemflow could be a determining factor of herb distribution by affecting and establishing microhabitats underneath the overstory (Carl and Ralph 1984).

However, the herbaceous layer can also positively affect overstory plants. Elliott et al. (2015) reported greater rates of nitrogen mineralization, nitrogen availability, greater tree litterfall mass, and total tree litterfall $\mathrm{N}$ in experimental plots with added herbaceous biomass compared to plots where the herbaceous layer had been removed.

\section{$\underline{\text { Microbial Interactions }}$}

The understory also has an effect on soil microbial abundance. Wu et al. (2011) observed that removing the understory significantly reduced the amount of phospholipid fatty acids (PLFAs) (an estimate of microbial biomass) found in the soil and reduced the fungi to bacteria ratio, concomitant with an increase in soil temperature and reduced $\mathrm{N}$ availability. Similarly, Xiaoli et al. (2015) found that increased understory abundance and tree diversity led to an increase of the fungi to bacteria ratio in the soils of plantation forests. If the greater fungi to bacteria ratio was due to an increase in mycorrhizal fungi, increased understory abundance would lead to better plant growth (positive feedback) as increased colonization of plant roots by 
mycorrhizal fungi has been found to be associated with higher plant biomass and phosphorus content (Treseder 2013).

In temperate deciduous forests, the most common types of mycorrhiza are arbuscular mycorrhiza (AM) and ectomycorrhiza (ECM). Examples of AM associated trees are maples (Acer spp.), tulip poplar (Liriodendron tulipifera), and black cherry (Prunus serotina); examples of ECM associated trees are oaks (Quercus spp.) and American beech (Fagus grandifolia) (Allen et al. 1995). Mycorrhizal type correlates with tree growth and nutrient dynamics (Cornelissen et al. 2001). For example, trees with AM associations tend to have a faster relative growth rate, higher levels of $\mathrm{N}$ and $\mathrm{P}$ in their leaves, faster litter decomposition, and have a lower rate of carbon sequestration than trees associated with ECM. ECM trees invest more energy in structural (lignin) and chemical defenses, necessitating higher carbon sequestration rates yet potentially slowing their growth rate (Coley 1988; Cornelissen et al. 1998; Cornelissen et al. 2001). High-lignin litter from ECM trees breaks down more slowly than litter of AM trees (Cornelissen et al. 2001); the different nutrient turnover rates around ECM than AM trees may affect the herbaceous layer.

\section{Effects of Nitrogen on the Herb Layer}

Nitrogen is the fourth most abundant element in cellular biomass, a macronutrient essential for growth and reproduction (Stein and Klotz 2016). Nitrogen cycling in ecosystems is originally derived from three main sources: biological nitrogen fixation, mineralization, and atmospheric deposition (Bobbink et al. 2010). During biological nitrogen fixation, plants (mostly legumes) convert atmospheric nitrogen $\left(\mathrm{N}_{2}\right)$ into ammonia $\left(\mathrm{NH}_{3}\right)$ with the help of symbiotic bacteria in their roots. Mineralization comprises the processes of converting organic nitrogen into inorganic forms of nitrogen (via microbes) and can vary with soil temperature, moisture, and aeration. Atmospheric deposition is the process of nitrogen being transferred from the 
atmosphere to Earth's surface in the form of particles or gases (dry deposition) or dissolved in precipitation (wet deposition) (Paerl et al. 2002).

Excess nitrogen from anthropogenic activities has led to an increase in nitrogen deposition in the eastern U.S. forests (Driscoll et al. 2003). An increase in atmospheric nitrogen deposition is known to reduce plant diversity in forests, especially in the herb layer (Gilliam 2006). As the herb layer is sensitive to nutrient availability, nitrogen additions can create a competitive environment (Muller 2014) supporting the survival and growth of nitrophilic species while decreasing plant biodiversity and species richness (Rajaniemi 2002, Bobbink et al. 2010). Nitrophilic species are commonly measured by the Ellenberg $\mathrm{N}$ score, which is based on the natural occurrence of plant species along a soil nitrogen gradient (Moreau et al. 2013). The index ranges from 1 to 9 based on their attraction toward N, with 9 being the highest level of nitrophily (Walter et al. 2017). Species loss due to nitrophilic species was demonstrated by Walter et al. (2016) at the Fernow Experimental Forest (FEF) in the Appalachian Mountains of West Virginia. After 25 years of adding nitrogen fertilizer to a watershed, the cover of nitrophilic Rubus spp. had increased from 1 to $19 \%$ of total herb cover. Walter et al. (2016) concluded that the increase in Rubus cover was consistent with the $\mathrm{N}$ homogenization hypothesis (Gilliam 2006), stating that, as an ecosystem shifts from $\mathrm{N}$ limitation to $\mathrm{N}$ saturation due to the homogenous supply of soil nutrients, species richness decreases due to the exclusion of $\mathrm{N}$ efficient species by nitrophilic species (Gilliam 2016).

\section{Sugar Maple and Red Maple as Predictors of Soil Nitrogen}

Sugar maple (Acer saccharum Marsh.) and red maple (Acer rubrum L.) are dominant and widely distributed tree species of the hardwood forests of the northeastern US. Studies have shown that these species are unique and critical with regard to nitrogen cycling in forest ecosystems (Lovett and Mitchell 2004, Peterjohn et al. 2015). Peterjohn et al. (2015) investigated associations of tree species and nitrate availability across spatial scales at the FEF. 
The researchers observed that, at the scale of individual trees, small plots, and entire watersheds, sugar maples_-in contrast with red maples—strongly correlated with higher soil nitrate availability. At the scale of individual trees, the study found lower soil C:N ratios and higher soil $\mathrm{pH}$ values around sugar maples relative to red maples.

The distribution and abundance of sugar and red maple may be changing. In some locations, sugar maple populations may be increasing due to reduction of one of their main competitors, American beech (Fagus grandifolia Ehrh.), which is affected by beech bark disease (Lovett et al. 2010). However, several factors, including acid deposition, climate change, and the introduction of a new insect pest (i.e., the Asian long-horned beetle), threaten populations of sugar maple in the future. Acid deposition can increase sulfate and nitrate leaching from soils. These fluxes can accelerate leaching of other nutrients, e.g. Ca, and thus negatively affect the growth of sugar maple trees. This occurs predominately in trees growing on base-cation-poor sites (Horsley et al. 2000, Lovett and Mitchell 2004). Climate change can limit or shift the range of sugar maple by affecting the amount of moisture and nutrients in the soil (Fei et al. 2017). The Asian long-horned beetle prefers to feed on maples and bores large holes into the trunk of the tree, which will eventually cause mortality by disrupting the tree's vascular tissues and weakening the wood structure (Lovett and Mitchell 2004; Haack et al. 2010).

Red maple does reasonably well in a wide variety of habitats and ecological conditions. It possesses the physiological, morphologically, and growth characteristics of both early and late successional tree species, which might explain the difference between sugar and red maple in terms of soil nitrate availability (Abrams 1998). These traits, which are rare among plant species, have allowed red maple to increase in numbers despite a wide range of environmental changes. As an early successional species, red maple can be opportunistic, following forest disturbances and agricultural abandonment. Subsequently, red maple can persist and spread in many forest types due to requiring relatively lower amounts of water, nutrients, and light for 
survival. This species has also increased in many forests that were affected by deer overabundance or gypsy moths. Red maple is less preferred by herbivores than most other trees, because of the influence of alkaloids in their foliage (Barbosa and Krischik 1987, Abrams 1998).

Changes in the abundance of sugar maple could lead to major changes in nitrogen retention in watersheds in the eastern US. As mentioned above, sugar maples are associated with soils having high rates of nitrification, i.e. nitrate production. Nitrate, the most mobile form of inorganic nitrogen, is readily lost from an ecosystem by leaching below the rooting zone (Lovett and Mitchell 2004). While the study of Peterjohn et al. (2015) could not determine whether tree species cause or reflect patterns of soil nitrate availability, their results supported the hypothesis that the nature of leaf litter alters soil $\mathrm{C}: \mathrm{N}$ ratios in ways that influence rates of nitrification (Lovett et al. 2002, Lovett and Mitchell 2004). With the herb layer potentially contributing a significant amount of litter, and with its high foliar concentrations of $\mathrm{N}, \mathrm{P}, \mathrm{K}$, and $\mathrm{Mg}$ and low concentrations of lignin and cellulose (Chapin 2003), the herb layer has the potential to lower soil C:N ratios and increase nitrification rates thus either amplifying the stimulating effect of sugar maple or buffering against the dampening effect of red maple on nutrient cycling (Figure 10).

\section{Long-term Effects of Forest Harvest on the Herb Layer}

Anthropogenic disturbances have largely replaced natural disturbances in forest ecosystems (Oheimb and Härdtle 2009). The intensity of the disturbance can affect the amount of time for the forest to return to its natural state (Gilliam 2007). These disturbance events, mostly tree harvesting, can create gaps in the canopy that allow more light to reach the forest floor increasing species richness with disturbance severity. At the Fernow Experimental Forest, Walter et al. (2016), observed that Rubus spp. cover increased with increasing canopy openness under adequate $\mathrm{N}$ supply. While these light-mediated short-term effects are well 
known (Gotmark et al. 2005), less is known of how (or if) longer time periods since the last harvest affect understory in a closed-canopy forest.

\section{Effects of Abiotic Factors on the Herb Layer}

Slope and aspect can affect the amount of solar radiation received by vegetative and soil surfaces. Solar radiation creates microclimates influencing decomposition and nutrient availability by affecting soil temperature and soil moisture content (Bennie et al. 2008; Cantlon 1953; Maren et al. 2015). Aspect can influence soil moisture by effecting the rate of evapotranspiration (Hawley et al. 1983), with south-facing slopes generally having drier soils than north-facing slopes. Mudrick et al. (1994) reported that litter decomposition was faster on northerly than on southerly aspects in hardwood forests. With northerly aspects having more soil moisture and higher microbial activity (Kang et al. 2009), N availability can be expected to be higher relative to watersheds with southerly aspects (Peterjohn et al. 2015). Slope steepness can also affect soil moisture with steeper slopes having drier soils than gentle slopes (Bennie et al. 2008). As soil moisture stress is one of the most important abiotic stresses that affects yield and reproduction in plants, slope and aspect certainly play an important role in understory cover and diversity.

\section{$\underline{\text { Research Justification and Objectives }}$}

Compared to the tree component, relatively little is known about the contributions of the biodiversity and abundance of the herbaceous layer to forest functioning in general and to the functioning of forests with varying nitrogen deposition levels, land use history, and abiotic factors in particular. It is also unknown whether herb layer characteristics vary beneath trees of different species. Given that different tree species have been associated with different levels of soil nitrate availability and that biodiversity may be positively correlated with nutrient retention, the herbaceous layer under different tree species warrants investigation. With climate change, 
atmospheric $\mathrm{N}$ deposition, introduced pests, management practices, and other factors influencing forest ecosystems, a better understanding of the contributions of all components of the ecosystem to its functions will help practitioners adaptively manage forest resources for sustained delivery of ecosystem goods and services. This research project primarily aimed to fill a current knowledge gap and, secondarily, to provide the basis for studying the role of understory nitrogen cycling in future studies. The specific objectives were to:

1. Quantify herb species composition, cover, and biomass under two different Acer species $H_{o}$ : There is no difference in herb layer characteristics under sugar maple and red maple within a given watershed.

$H_{a}:$ Herb layer characteristics differ under sugar maple and red maple.

2. Quantify herb species composition and cover under two different Acer species in watersheds with different levels of $\mathrm{N}$ deposition

$H_{0}$ : There is no difference in herb layer characteristics between a fertilized watershed (WS3) and an unfertilized reference watershed (WS7).

$H_{a}$ : Herb layer characteristics differ between a fertilized watershed (WS3) and an unfertilized reference watershed (WS7).

3. Quantify herb species composition and cover under two different Acer species in watersheds with different stand ages

$H_{0}$ : There is no difference in herb layer characteristics between a watershed with 60-yearold trees (WS7) and a watershed with 110-year-old trees (WS13).

$H_{a}$ : Herb layer characteristics differ between a watershed with 50-year-old trees (WS7) and a watershed with 110-year-old-trees (WS13).

4. Quantify herb species composition and cover under two different Acer species in watersheds with different aspects

$H_{0}$ : There is no difference in herb layer characteristics between a watershed with a northerly aspect (WS13) and a watershed with a southerly aspect (WS10).

$H_{\mathrm{a}}$ : Herb layer characteristics differ between a watershed with a northerly aspect (WS13) and a watershed with a southerly aspect (WS10). 


\section{Materials and Methods}

Study Site

This study took place at the Fernow Experimental Forest (FEF), located in Tucker County in north-central West Virginia (Figure 1). The FEF lies within an area classified as the Allegheny Mountain Section of the Central Appalachian Broadleaf Forest (Adams et al. 1993). The growing season extends from May through October, with tree leaves emerging in late April and being fully developed by mid-June. Leaves begin to fall in October. The mean annual precipitation is approximately $1460 \mathrm{~mm} \mathrm{yr}^{-1}$ (122 $\mathrm{mm}$ per month on average) with somewhat higher precipitation occurring during the growing season (March through August) (Adams et al. 1994, Gilliam et al. 1994). The mean monthly air temperatures range from $-2.8^{\circ} \mathrm{C}$ in January to $20.4^{\circ} \mathrm{C}$ in July (Adams et al. 2012). The most common soil at FEF is Calvin channery silt loam (loamy-skeletal, mixed, active, mesic Typic Dystrudept) (Adams 2012). All study watersheds support vegetation originating from natural regeneration. The dominant overstory species include sugar maple (Acer saccharum Marsh.), sweet birch (Betula lenta L.), American beech (Fagus grandifolia Ehrh.), yellow tulip poplar (Liriodendron tulipifera L.), black cherry (Prunus serotina Ehrh.), and northern red oak (Quercus rubra L.) (Adams et al. 2006), but their relative importance varies both within and between the watersheds being studied. 


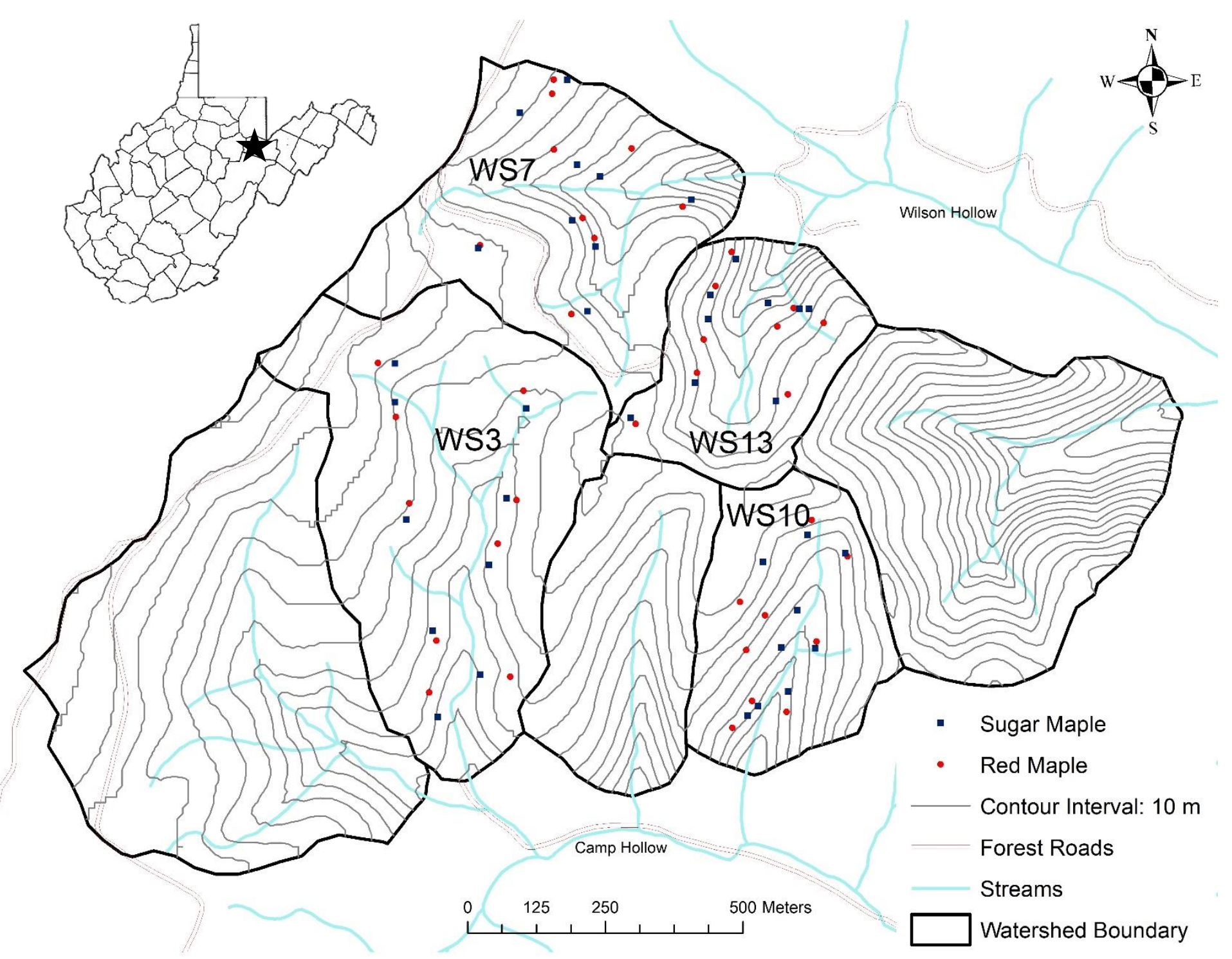

Figure 1. Location of Fernow Experimental Forest (insert) and watersheds used in this study (WS3, WS7, WS10, WS13). Location of study plots are marked by the tree at the plot center (square - sugar maple, circle - red maple). 
Watersheds are in close proximity to each other (Figure 1) and are similar with respect to soil series, geology, climate, and natural disturbance history; watersheds differ in regard to slope (Figure 2, Table 1) and human-related disturbance history (detailed below).

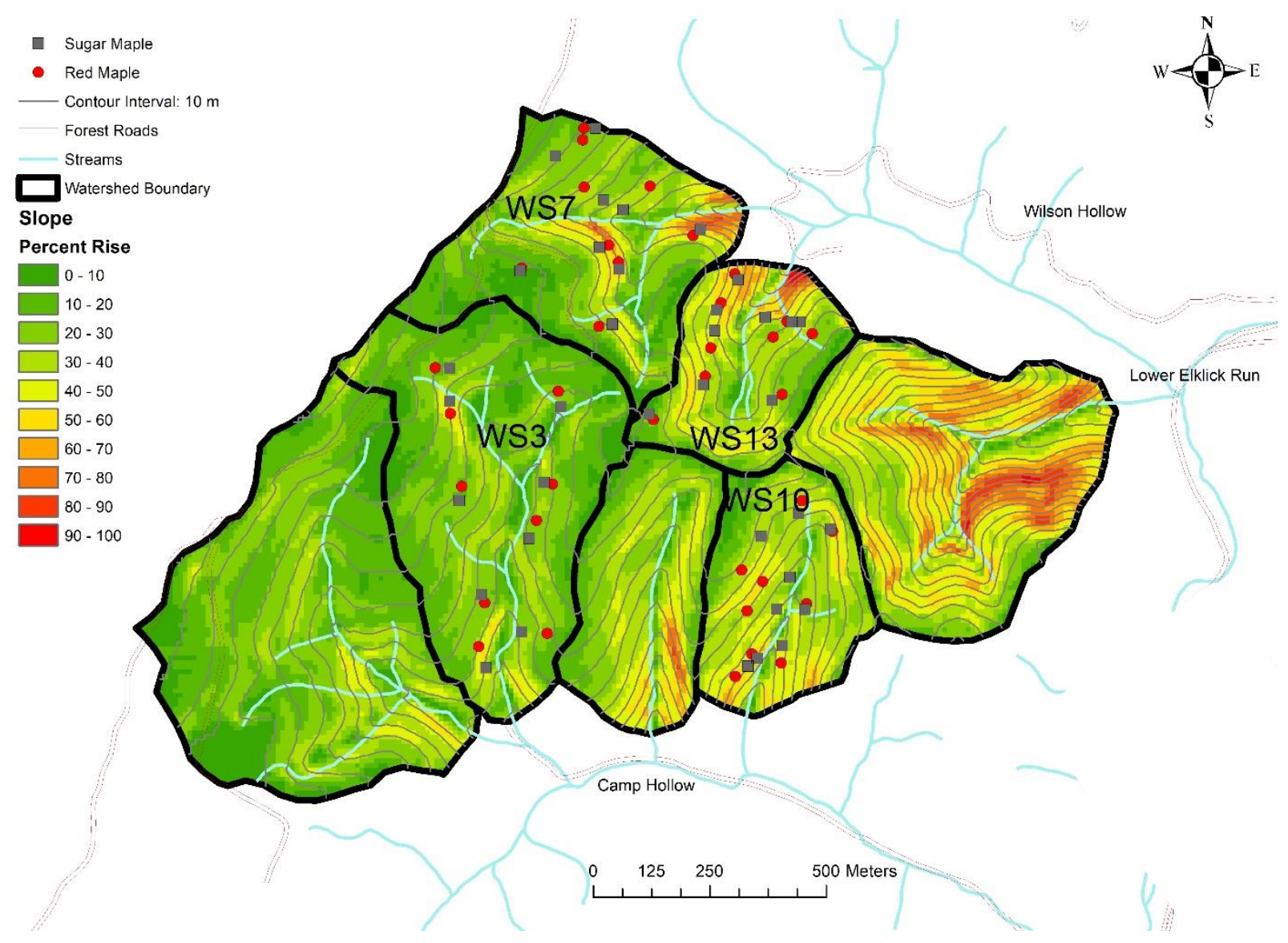

Figure 2. Slopes (in \%) of the study watersheds (WS3, WS7, WS10, WS13) at the Fernow Experimental Forest. Location of study plots are marked by the tree at the plot center (square sugar maple, circle - red maple). 
Table 1. Characteristics of the watersheds in the study.

\begin{tabular}{|c|c|c|c|c|c|c|c|c|}
\hline $\begin{array}{l}\text { Watershed } \\
\text { ID }\end{array}$ & Location ${ }^{*}$ & $\begin{array}{c}\text { Area } \\
\text { (ha) }\end{array}$ & $\begin{array}{l}\text { Elevation } \\
\text { (m) }\end{array}$ & Aspect & $\begin{array}{c}\text { Average } \\
\text { Slope } \\
\text { (Range) \% }\end{array}$ & $\begin{array}{c}\text { Dominant Tree } \\
\text { Species }^{\star \star}\end{array}$ & $\begin{array}{c}\text { Stand } \\
\text { Age (yr) }\end{array}$ & Treatment \\
\hline 3 & $\begin{array}{l}39.05413 \mathrm{~N} \\
79.68625 \mathrm{~W}\end{array}$ & 34.3 & $730-860$ & $\mathrm{~S}$ & $20.6(0-60)$ & $\begin{array}{l}\text { black cherry, } \\
\text { red maple } \\
\text { sugar maple }\end{array}$ & $\sim 50$ & Fertilization \\
\hline 7 & $\begin{array}{l}39.06388 \mathrm{~N} \\
79.68029 \mathrm{~W}\end{array}$ & 24.2 & $730-860$ & $E$ & $25.8(0-90)$ & $\begin{array}{l}\text { tulip poplar, } \\
\text { sweet birch } \\
\text { black cherry }\end{array}$ & $\sim 50$ & Reference \\
\hline 10 & $\begin{array}{l}39.05411 \mathrm{~N} \\
79.68029 \mathrm{~W}\end{array}$ & 15.2 & 695-805 & $S$ & $33.4(0-70)$ & $\begin{array}{l}\text { red maple } \\
\text { American beech, } \\
\text { chestnut oak }\end{array}$ & $\sim 110$ & Reference \\
\hline 13 & $\begin{array}{l}39.06280 \mathrm{~N} \\
79.67917 \mathrm{~W}\end{array}$ & 14.2 & $610-830$ & NE & $35.2(0-100)$ & $\begin{array}{l}\text { sugar maple } \\
\text { American beech } \\
\text { red oak }\end{array}$ & $\sim 110$ & Reference \\
\hline
\end{tabular}

${ }^{*}$ Lowest point in the watershed, i.e. the location of the stream weir

${ }^{* *}$ Tree species are listed in order of descending cover/importance (see text below)

\section{Watershed 3}

Watershed 3 (WS3) has received fertilization/acidification treatments to study the effects of atmospheric $\mathrm{N}$ deposition since 1989. Since then, granular ammonium sulfate has been applied aerially three times a year at a rate of $7.1 \mathrm{~kg} \mathrm{~N} \mathrm{ha}^{-1}$ in March and November, and 21.2 $\mathrm{kg} \mathrm{N} \mathrm{ha}^{-1}$ in July (Peterjohn 2017). WS3 was logged around 1910 and only undesirable trees were left behind. In the 1940's, chestnut trees affected by chestnut blight were also removed from this watershed and the other watersheds in this study. Partial cuts were made in 1958, 1963, and 1968. In 1958, $14 \%$ of trees with a $\mathrm{DBH} \geq 12.7 \mathrm{~cm}(5.0 \mathrm{in})$ were cut and removed. In $1963,9 \%$ of the trees with the same DBH were removed, and finally in $1968,6 \%$ of trees of the same DBH were removed. The watershed was subsequently clearcut in 1969-1970; all saplings with a DBH between $2.5 \mathrm{~cm}$ and $12.5 \mathrm{~cm}$ (1 in to $4.9 \mathrm{in}$ ) were sprayed with herbicide and trees with a DBH > $12.7 \mathrm{~cm}$ (5.0 in) were cut (Trimble 1986); a 3-ha riparian/protection buffer strip (approximately 10-20 m wide and $730 \mathrm{~m}$ long) was initially left along each side of the perennial stream to help protect water quality until it was removed in 1972 (Adams et al. 1994; Aubertin and Patric 1974; Peterjohn 2017). In 2004, the dominant tree species (\% basal area) in this 
watershed were black cherry (51), red maple (11.5), sugar maple (11.3), sweet birch (5.1), and American beech (2.5) (Adams et al. 2007).

\section{Watershed 7}

To assess fertilization/acidification effects in WS3, watershed 7 (WS7) is used as a reference watershed since these watersheds have a similar stand age. The upper half of the watershed was clearcut from 1963 - 1964; the lower half was clearcut from 1966 - 1967. Following the clearcuts, the watershed was then herbicided annually till 1969, allowing vegetation to naturally regenerate thereafter (Peterjohn 2017, Adams 2012). In 2004, the dominant vegetation (\% basal area) for this watershed are yellow tulip poplar (26.2), sweet birch (20.5), black cherry (20.5), red maple (8.2), and sugar maple (4.9) (Adams et al. 2007).

\section{Watershed 10}

Watershed 10 (WS10) serves as an "unmanaged" reference watershed (Peterjohn 2017). The last known clearcut in this watershed took place between 1905 and 1910. In 2000, the dominant tree species (as relative importance values) in this watershed were red maple (22\%), American beech (15\%), chestnut oak (12\%), red oak (12\%), and sugar maple (7\%). Relative importance values are calculated by averaging the relative dominance (based on basal area), relative density, and relative frequency of each of the tree species (Peterjohn et al. 2015).

\section{Watershed 13}

Watershed 13 (WS13) also serves as an "unmanaged" reference watershed (Peterjohn 2017). Around 1910, it was heavily cut, along with WS10 (Trimble 1986). In the early 1950s, the last harvesting (a partial cut) took place in this watershed. In 2000, the dominant tree species (relative importance values) in WS13 were sugar maple (23\%), American beech (15\%), red oak (12\%), and red maple (11\%) (Peterjohn et al. 2015). While both WS13 and WS10 serve as reference watersheds, they differ in watershed aspect (Table 1) and have contrasting maple 
importance values (WS13: sugar maples (23\%), red maples (11\%) versus WS10: sugar maples (7\%), red maples (22\%).

\section{Experimental Design}

Nine plot pairs per watershed were established in the summer of 2017 . Two adjacent plots, with one centering around a stem of sugar maple and the other around a stem of red maple, represent a site (Figure 3, Figure A1). The distance between plot centers of a red and sugar maple pair averaged $33 \mathrm{~m}$ (range: 6 - $83 \mathrm{~m}$ ) while the average distance between neighboring plot pairs (closest plot centers) was $113 \mathrm{~m}$ (range: 16 - $258 \mathrm{~m}$ ) (Figure 1). Selected plot-center trees were vigorous and had a diameter at breast height $(\mathrm{DBH})$ of at least $10 \mathrm{~cm}$ (Table A1, Appendix). Tree locations were marked using a Garmin eTrex20 (Table A1, Appendix). Within each plot (summing up to a total of 72 plots across four watersheds), data on herb layer species composition, cover, and factors that may influence the herb layer were collected from June through August 2018.

\section{Red Maple (Acer rubrum) Sugar Maple (Acer saccharum)}

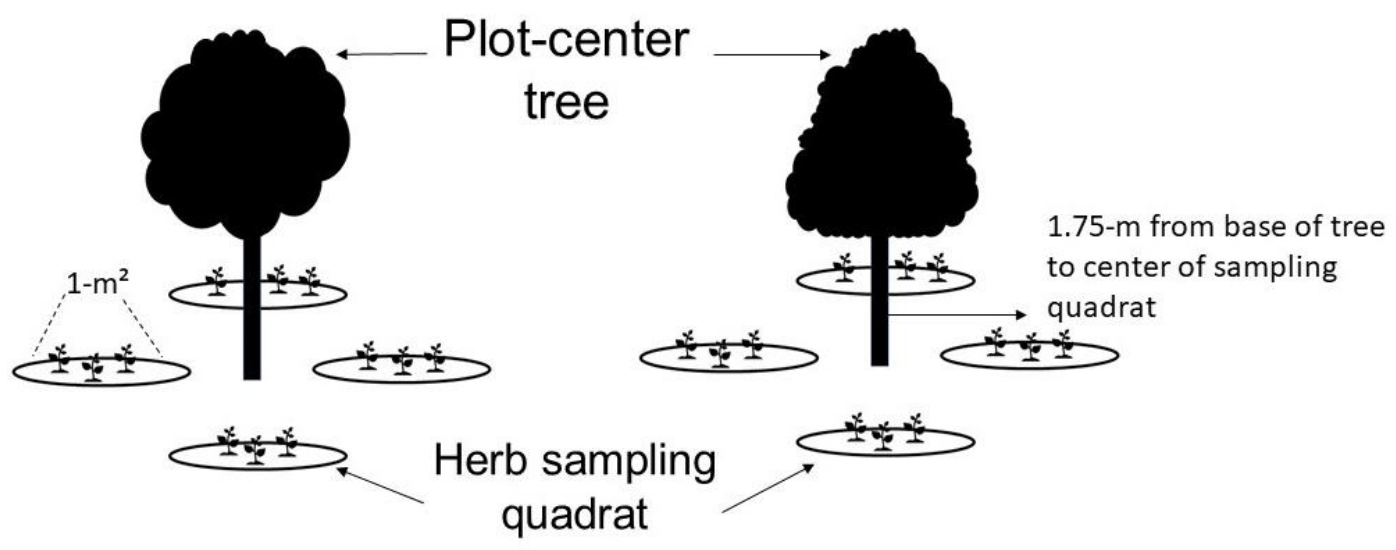

Figure 3. Experimental design of plot pairs at each site (replicated nine times in each watershed) for collecting herb composition and cover. 


\section{Data Collection}

Characteristics of the herbaceous layer $<1 \mathrm{~m}$ tall were assessed in four circular $1-\mathrm{m}^{2}$ herb sampling quadrats established at the four cardinal directions $(N, S, E, W)$ from the plot center tree (Figure 3). The sampling quadrat's center was $1.75 \mathrm{~m}$ away from the base of the plot center tree, roughly halfway between the stem and the edge of the crown to avoid stem flow and canopy drip.

Within each sampling quadrat, herb layer composition was determined by identifying most plants to the species level, with exceptions for grasses and sedges (identified as graminoids), and Rubus spp., Viola spp., and Anemone spp. (identified to genus level). These taxonomically difficult groups were not identified to species level to limit misidentification. For example, in the Fernow Experimental Forest, the vast majority of Rubus individuals are Rubus allegheniensis (blackberry), but there is also Rubus idaeus (raspberry) at this location. Rubus species can hybridize and are difficult to identify without fruit or flowers (Walter et al. 2016). These exceptions likely resulted in an underestimation of species richness. Diversity indices would have been affected to a lesser extent. As graminoids and Anemone species had low abundance and Rubus was likely $R$. allegeniensis, these taxa would have been appropriately represented in diversity and evenness calculations.

For each taxon, cover was measured as leaf area using the hand-area $(\mathrm{HA})$ method (Walter et al. 2015). In brief, the HA method compares the area of a hand with the area of the individual leaves of a plant or species. The observer places a hand, palm side down, and fingers closed, directly above the leaves or leaflets of the species they are measuring within the sampling quadrat. The observer then determines the size of the leaf in relation to their hand, either as individual or group, until all leaf or leaflet surfaces are observed within the quadrant. A full hand is equivalent to $1 \%$ of $1 \mathrm{~m}^{2}$ and half a hand is $0.5 \%$ (Figure 4 ). To improve the 
accuracy and precision, a) observer hands were adjusted to $1 \mathrm{dm}^{2}$ by folding under the thumb and or fingertips depending on the actual size of the observer's hand and b) two observers independently recorded cover, and the average of the two estimates was recorded (Walter et al. 2015). Cover is expressed as total cover ( $\mathrm{dm}^{2}$ of plant surface) per individual species or all species combined, or as relative cover (total cover of 1 taxon / sum of total cover of all species) per watershed.

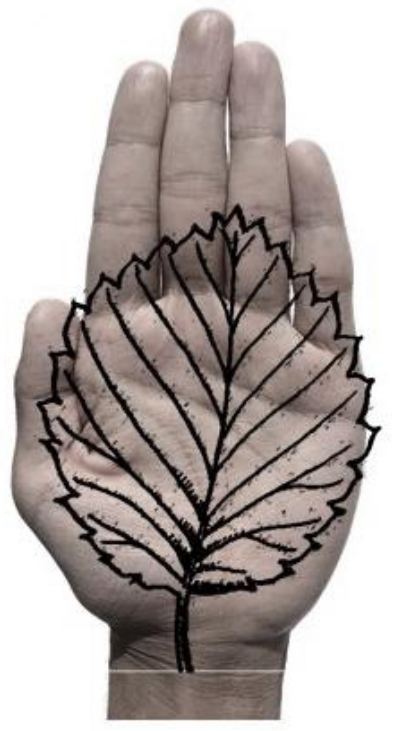

Half a hand $=0.5 \%$

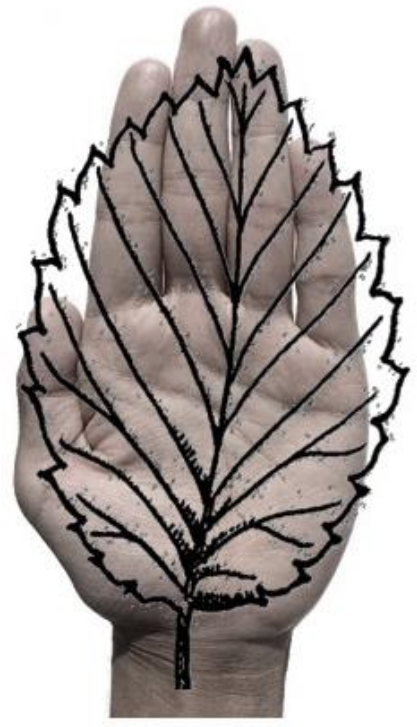

Full hand $=1 \%$

Figure 4. Visual illustration of the hand-area method. Half of a hand is equivalent to $0.5 \%$ and a full hand is equivalent to $1 \%$ of a $1-\mathrm{m}^{2}$ sampling quadrat (assuming the hand area is $1 \mathrm{dm}^{2}$ ).

Species Richness (S), Shannon-Wiener Diversity $(\mathrm{H})$, and Pielou's Eveness $(\mathrm{J})$ were calculated from the collected data. Species Richness is the number of species per unit of area. Shannon-Wiener Diversity, an index commonly used to characterize species diversity, accounts for both abundance and evenness of species present (Begon 1996). H will increase with increasing species richness and with increasingly equitable contributions of the species to the community. Pielou's Evenness is another measure of diversity. Values for $\mathrm{J}$ are the ratio of 
actual $\mathrm{H}$ to maximally possible $\mathrm{H}$ (if all species were present in equal proportion). Thus, values for $\mathrm{J}$ are constrained between 0 and 1 ; with $\mathrm{J}=1$ indicating that all species in each area are present in equal proportions; if $\mathrm{J}$ is close to zero, it indicates the presence of a strongly dominant species (Pielou 1975; Begon 1996).

The Shannon-Wiener Diversity Index is calculated as

$H=-\sum_{i=1}^{s} P i \ln P i$

where $P i$ is the relative abundance of each herbaceous species in the total quadrat and where $s$ is the number of species (Shannon and Weaver 1949).

Pielou's Evenness Index is calculated as

$J=\frac{H}{H_{\max }}=H / \ln S$

where $H$ is the Shannon-Wiener Diversity Index and $S$ is the total number of species (Pielou 1975).

To characterize the abiotic environment of the herb layer, several additional measurements were conducted either on the same day as herb characteristics were measured (i.e. canopy cover) or in August. In order to quantify the light environment for the understory, percent canopy cover was measured with a densiometer over each sampling quadrat while facing the plot-center tree. The four measurements were then averaged in each plot. Slope was measured using a clinometer and aspect using a compass; both measurements were taken at the plot center facing downhill. The distance from the plot center to perennial stream was quantified using ArcMap, as water availability can affect the abundance and diversity of herbaceous plants. To align aspect with productivity and to be able to analyze it as a continuous variable, aspect was transformed into a linear scale that ranges from $0-2$, with the value zero 
being southwest (lowest productivity) and the value two being northeast (highest productivity) using the formula: $\mathrm{A}^{\prime}=\sin (A+45)+1$, where $\mathrm{A}^{\prime}$ is the transformed aspect code and $\mathrm{A}$ is the aspect defined as the direction of the prevailing slope (Beers et al. 1966).

To assess potential influence of neighboring trees on herb characteristics below the plot center tree, $\mathrm{DBH}$ of the five closest neighboring trees was measured. Neighbor trees were separated by ectomycorrhizal (ECM) or arbuscular mycorrhizal (AM) association and basal area $\left(B A, m^{2} h^{-1}\right)$ was calculated for each association (Figure 5). The fifth-nearest tree from the plot center was used as the radius of the plot area (ha), by which the sum of the stem crosssectional area $\left(\mathrm{m}^{2}\right)$ of ECM or AM trees was divided (Table A2, Appendix).

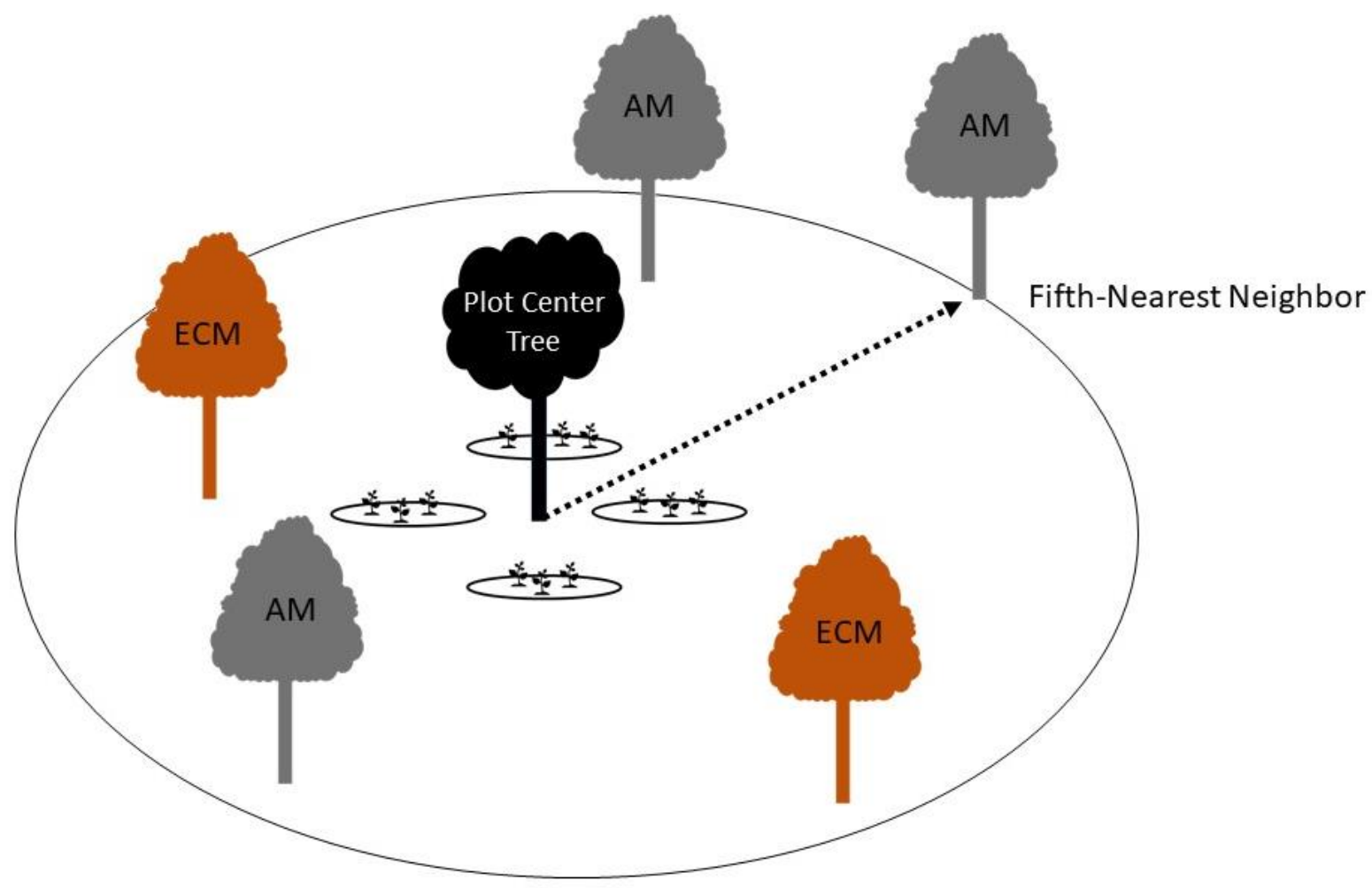

Figure 5. Visual illustration of how the five closest neighboring trees were separated by ectomycorrhizal (ECM) or arbuscular mycorrhizal (AM) association. Basal area (BA, $\mathrm{m}^{2} \mathrm{ha}^{-1}$ ) was calculated for each association by using the fifth-nearest tree as the radius of the plot area (ha) by which the sum of basal area $\left(\mathrm{m}^{2}\right)$ of ECM or AM trees were divided. 


\section{$\underline{\text { Statistical analysis }}$}

Analysis of variance (ANOVA) was conducted separately for the following watershed pairs: WS3-WS7 (differ in fertilization level; similar, "younger" stand age); WS7-WS13 (differ in stand age; similar aspect); WS10-WS13 (differ in watershed aspect; similar, "older" stand age). Watersheds were analyzed in these pairs to prevent statistical confounding, as the watersheds differed in various known independent characteristics (stand age, recent fertilization, aspect). Residuals were checked for normality and variables were transformed when necessary. Graphs and tables presented use untransformed data. Repeated measures ANOVA were undertaken to account for the spatial correlation between sugar maple/red maple plot pairs within each site (Figure 3) (SAS code: Repeated Tree $/$ Subject $=$ Site $\left.{ }^{*} W S\right)$. All models evaluated the main effects of watershed (WS) and overstory maple species (sugar and red maple) (M) and watershed $\times$ maple species interactions $(W S \times M)$ on herb layer characteristics (cover, $S, H, J$ ). Watershed is used in the sense of "treatment", i.e. fertilized vs unfertilized in WS3 and WS7, respectively, younger vs older (referring to the stand age) in WS7 and WS13, respectively, and northerly aspect vs southerly watershed aspect in WS13 and WS10, respectively. Additional predictor variables included in the initial full (saturated) model were slope, DBH of plot-center tree, percent tree canopy cover, aspect, distance to stream, and basal area (BA) of neighboring ectomycorrhizal trees (BA ECM) and arbuscular mycorrhizal trees (BA AM). In watershed pair WS10-WS13, plot-level aspect is used as a predictor variable in addition to watershed (WS). Inclusion of plot-level aspect is justified by individual plots not having strict north versus south aspects as the whole watersheds (WS13 and WS10, respectively); and including watershed, while hypothesized to represent watershed aspect, is justified as it retains the capability to detect unmeasured differences between the watersheds. A reduced model was created from the full model, by removing predictor variables (other than watershed, overstory maple species, and their interaction) if they had high $\mathrm{p}$-values. Final model selection (full versus reduced model) 
was determined by the lowest AIC value. Four pairwise comparisons were conducted within each watershed pair (using the slicing option in SAS Proc Mixed), comparing herb layer responses a) between the two overstory maple species per watershed and b) between the two watersheds under a given overstory tree species. There was no adjustment made for multiple comparisons, but the number of comparisons were minimized to four in order to reduce false positives (Type I error). In all statistical analyses, significance criterion alpha for all tests was 0.05 and a statistical trend was declared when $\mathrm{P} \leq 0.1$.

In order to determine associations between individual understory plant species with watershed and overstory maple species, we first selected individual herb species that occurred in multiple sites in at least two watersheds. A total of 22 herb species (or genus for those identified to only genus level) were selected to test whether variations in cover were a response to watershed, overstory maples species, and WS $\times$ M interactions in each of the three defined watershed pairs. Since the probability of a Type I error increases with the number of tests conducted (familywise error rate), the Benjamini-Hochberg method was applied to control the false discover rate (i.e. a false positive or a Type I error). The concept is similar to the Bonferroni adjustment for multiple comparisons, yet less conservative in order to account for the large number of tests conducted (McDonald, 2014). To perform the Benjamini-Hochberg method, P-values from the 22 individual ANOVAs are ranked from smallest to largest. The smallest $\mathrm{P}$-value receives a rank (i) of 1 , the next larger $\mathrm{P}$-value receives the rank of 2 and so on. Next, each P-value is compared to the Benjamini-Hochberg critical value $(\mathrm{i} / \mathrm{m}) \mathrm{Q}$, where $\mathrm{i}$ is the rank, $m$ is the total number of tests (total number of individual $P$-values ranked), and $Q$ is the false discovery rate selected by the researcher (McDonald 2009). In this study, the false discovery rate was set at 0.10 . For the cover of a plant species to vary significantly by WS, M, or $\mathrm{WS} \times \mathrm{M}$, the P-value must be smaller than the Benjamini-Hochberg critical value. For example, with 22 species and 2 main effects (WS, M) and an interaction effect, there is a family of 66 
analyses (i.e. $n=66$ ). For the smallest $P$-value obtained by ANOVA to be considered significant, it would have to smaller than $1 / 66^{\star} 0.1=0.0015$; the $P$-value at rank 2 would have to be smaller than $2 / 66^{\star} 0.1=0.003$, etc. All P-values that are greater than the Benjamini-Hochberg critical value are considered not significant.

While the analyses of the overstory maple species effect on herb characteristics are truly replicated, the analyses of differences between watersheds is pseudo-replicated, i.e. no inference can be made beyond the watershed pairs used in this case study. Statistical analyses were carried out using JMP and SAS software (JMP®), Version Pro 12.2, SAS Institute Inc., Cary, NC, Copyright (C2015; SAS®, Version 9.3, SAS Institute Inc., Cary, NC, Copyright @20022010).

\section{Results}

Among all four watersheds, there were a total of 64 taxa recorded: 58 species, three genera, two families, and one group of unknown species (mostly young seedlings). Twenty-nine taxa were found in plots in WS3, 47 in WS7, 35 in WS13, and 42 in WS10. Dominant herb layer species (expressed in relative cover) in plots of WS3 were Rubus spp. (40\%) and Dryopteris intermedia (14.4\%), in WS7 Dryopteris intermedia (19.6\%) and Rubus spp. (17.4\%), in WS13 Rubus spp. (27.3\%) and Quercus rubra (11.6\%) and in WS10 are Smilax rotundifolia (17.7\%) and Rubus spp. (16\%) (Figure 6). The taxa that were identified only to genus - Rubus spp., Viola spp., and Anemone spp. - comprised 33\%, $6 \%$ and $0.2 \%$ of total cover, respectively. Interpretation of the results should take this into account as the diversity indices may be lower as a result of not identifying to species level for these taxa. Graminoids (found in 13 sampling quadrats across 9 plots) and the unknown species group (found in four sampling quadrats across 3 plots) contributed 0.23 and $0.04 \%$ to total cover and, thus, had a negligible effect on diversity indices. 
Effects of overstory maple species (M) and watershed (WS) on total cover of dominant herb layer species are shown in Figure 7. Results of the statistical analyses are shown in Table 2. In the analyses (ANOVA) of herb characteristics in watershed pairs, overstory maple species (M) was not statistically significant as main effect in any of the models but there was a statistically significant effect or a trend of the WS $\times$ M interaction in seven of the 12 models (Figure 8, Table 2). In these models, herb cover and/or diversity indices were lower under red than sugar WS3 and WS13 but not in WS7 and WS10. Watershed, in the sense of "treatment", affected the herbaceous layer in watershed pairs WS3 vs WS7 and WS7 vs WS13. In the fertilized watershed (WS3), species richness, diversity, and evenness were significantly lower than in the unfertilized watershed (WS7). In the comparison of the watershed with the younger stand ("younger watershed", WS7) with the watershed with the older stand ("older watershed", WS13), the younger watershed had higher cover, diversity, and evenness in comparison to the older watershed. In the comparison of the reference watershed with a northerly aspect (WS13) with the reference watershed with southerly aspect (WS10), cover and diversity indices did not differ (Figure 8, Table 2). Other biotic and abiotic factors differed between watersheds (Figure 9), and, as expected, also affected herb characteristics (Table 2). 


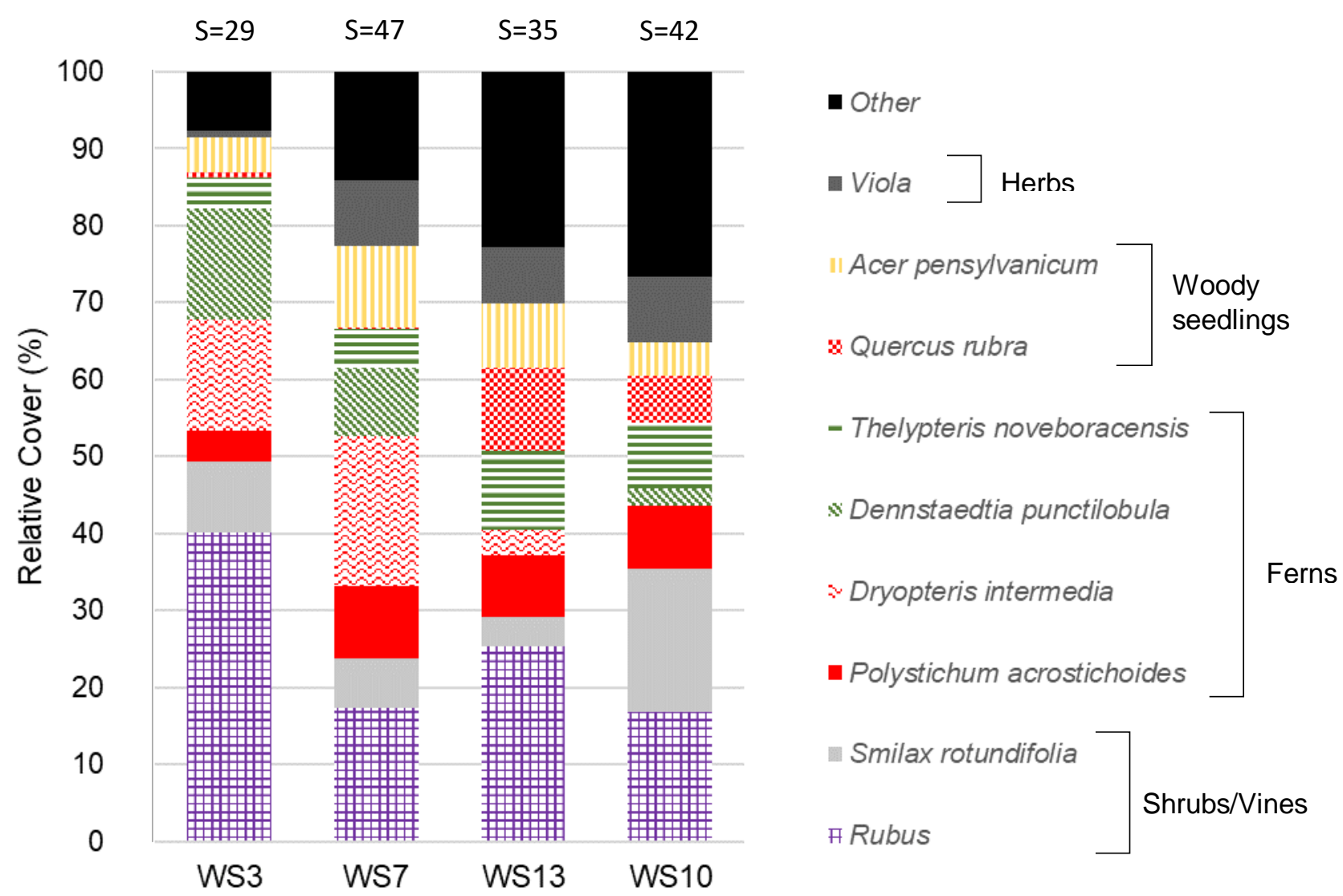

Figure 6. Relative cover of nine understory taxa and all other taxa combined in each watershed. $S$ indicates species richness in each watershed. 


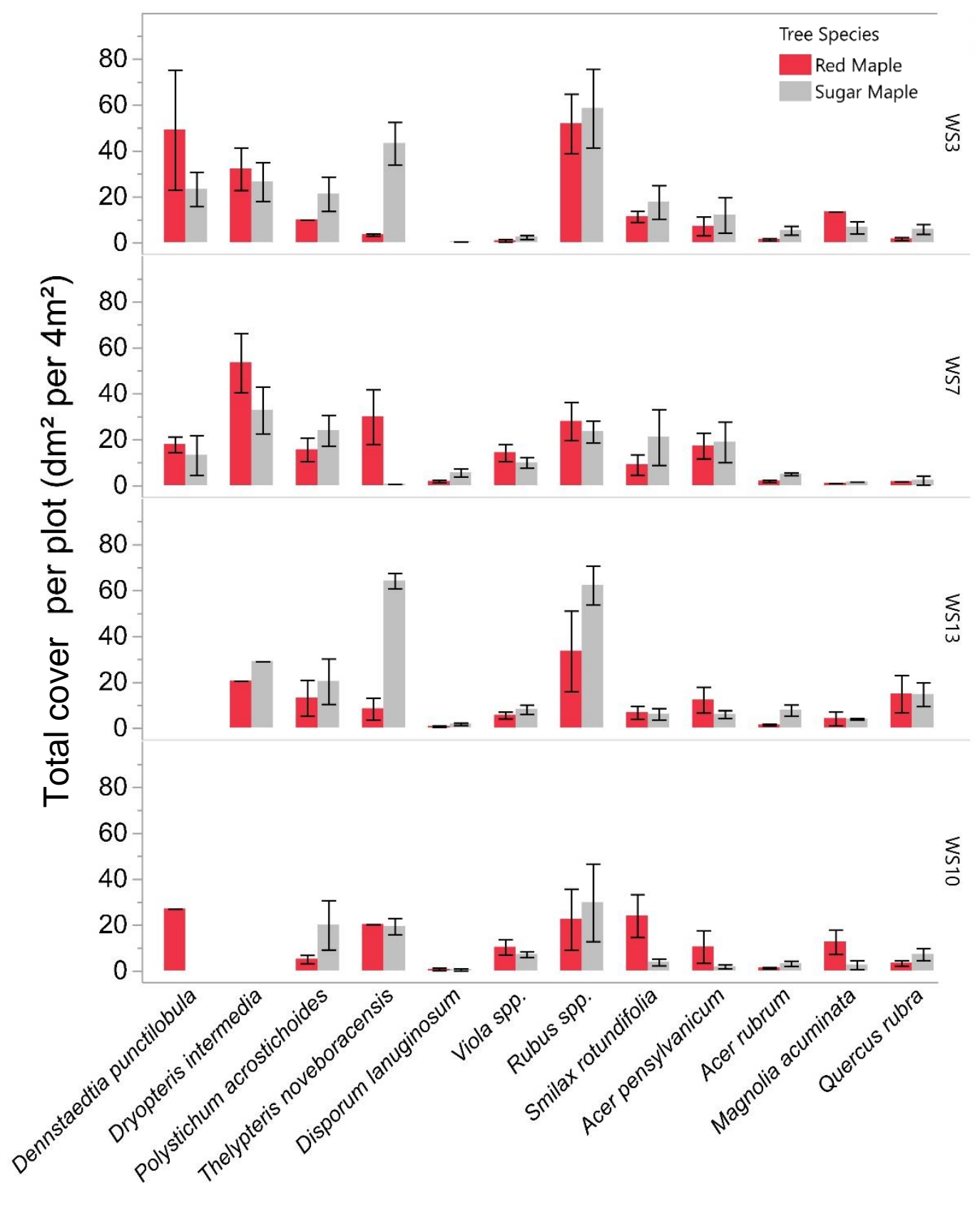

Ferns

Herbs Shrub/Vines Woody seedlings

Figure 7. Total cover per plot $\left(\mathrm{dm}^{2}\right.$ per $\left.4 \mathrm{~m}^{2}\right)$ of the most common understory plant species in WS3, WS7, WS10, and WS13. Error bars represent 1 SE. 


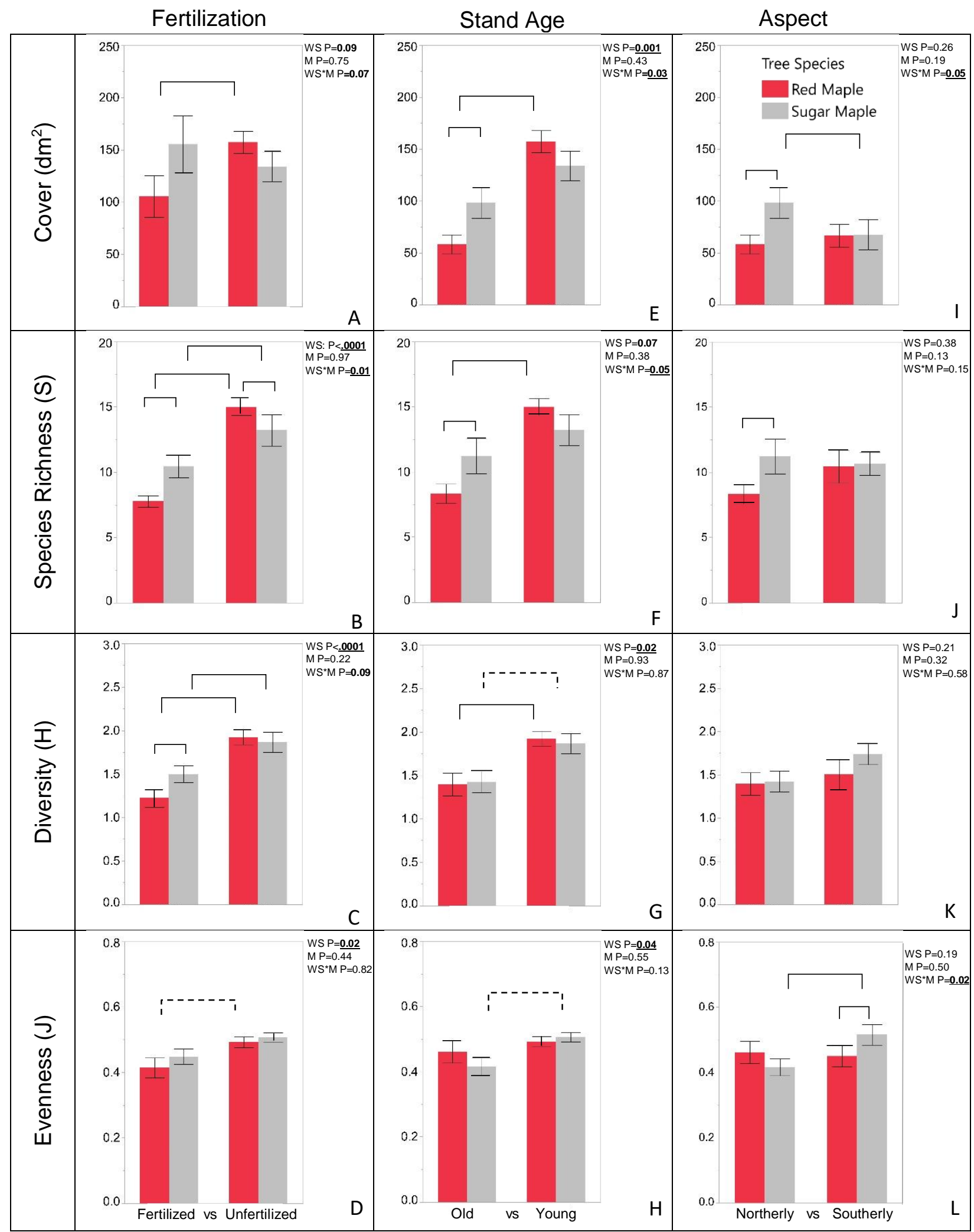

Figure 8. Herb characteristics in red and sugar maple (M) plots $\left(4 \mathrm{~m}^{2}\right.$ sampling area) in each of the studied watersheds (WS). Watershed comparisons are: fertilized (WS3) vs. unfertilized (WS7) younger stands $(A-D)$, younger stand (WS7) vs. older (WS13) reference stand (E-H), and older stands with northerly aspect (WS13) vs. southerly aspect (WS10) (I-L). Error bars represent 1 SE. Statistical results of main and interaction effects are excerpts from the final ANOVA model (Table 2 and Table A6). Horizontal brackets represent pairwise comparisons at $\mathrm{P} \leq 0.05$ (solid line) and $\mathrm{P} \leq 0.1$ (dashed line). 

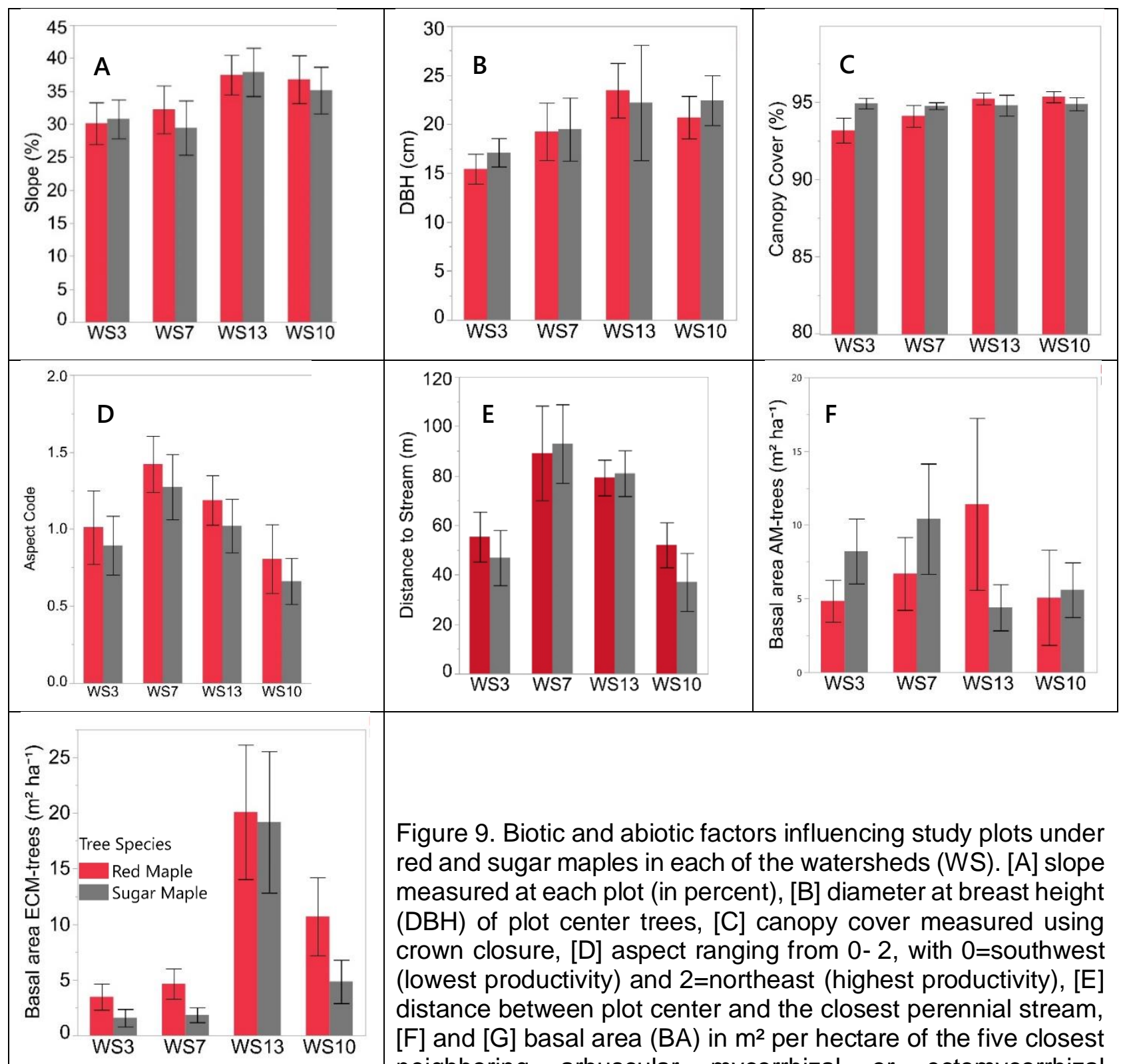

Figure 9. Biotic and abiotic factors influencing study plots under red and sugar maples in each of the watersheds (WS). [A] slope measured at each plot (in percent), [B] diameter at breast height $(\mathrm{DBH})$ of plot center trees, $[\mathrm{C}]$ canopy cover measured using crown closure, [D] aspect ranging from $0-2$, with $0=$ southwest (lowest productivity) and 2=northeast (highest productivity), [E] distance between plot center and the closest perennial stream, $[F]$ and $[\mathrm{G}]$ basal area (BA) in $\mathrm{m}^{2}$ per hectare of the five closest neighboring arbuscular mycorrhizal or ectomycorrhizal associated trees. Error bars represent 1 SE. 
Table 2. Results of the statistical analyses (ANOVA). P-values are shown below for full and reduced models. The final models selected for this study have the lowest AIC value (shown in bold) in the comparison between full and reduced model. Continuous predictor variables are explained in Figure 9.

\begin{tabular}{|c|c|c|c|c|c|c|c|c|}
\hline & \multicolumn{2}{|c|}{ Total Cover } & \multicolumn{2}{|c|}{ Species Richness, S } & \multicolumn{2}{|c|}{ Diversity, H } & \multicolumn{2}{|c|}{ Evenness, J } \\
\hline \multicolumn{9}{|l|}{ WS3 vs WS7 } \\
\hline & $\begin{array}{c}\text { Full } \\
\text { Model }\end{array}$ & $\begin{array}{c}\text { Reduced } \\
\text { Model }\end{array}$ & $\begin{array}{c}\text { Full } \\
\text { Model }\end{array}$ & $\begin{array}{c}\text { Reduced } \\
\text { Model }\end{array}$ & $\begin{array}{c}\text { Full } \\
\text { Model }\end{array}$ & $\begin{array}{c}\text { Reduced } \\
\text { Model }\end{array}$ & $\begin{array}{c}\text { Full } \\
\text { Model }\end{array}$ & $\begin{array}{c}\text { Reduced } \\
\text { Model }\end{array}$ \\
\hline AIC & 313.9 & 321.4 & 152.7 & 148.2 & 53.7 & 34.8 & -22.3 & -62.0 \\
\hline $\begin{array}{l}\text { Watershed } \\
\text { (WS) }\end{array}$ & 0.09 & 0.08 & $\leq .0001$ & $\leq .0001$ & $\underline{0.0002}$ & $\leq .0001$ & 0.06 & $\underline{0.02}$ \\
\hline $\begin{array}{l}\text { Overstory } \\
\text { Maple (M) }\end{array}$ & 0.75 & 0.66 & 0.90 & 0.97 & 0.62 & 0.22 & 0.58 & 0.44 \\
\hline WS $\times M$ & 0.07 & $\underline{0.05}$ & $\underline{0.004}$ & $\underline{0.003}$ & 0.17 & 0.09 & 0.96 & 0.82 \\
\hline Slope & 0.93 & & 0.01 & 0.01 & $\underline{0.03}$ & $\underline{0.02}$ & 0.13 & \\
\hline $\mathrm{DBH}$ & 0.37 & 0.28 & 0.77 & & 0.43 & & 0.26 & \\
\hline Tree Cover & 0.91 & & 0.68 & & 0.36 & & 0.08 & 0.19 \\
\hline Aspect & 0.36 & 0.31 & 0.02 & 0.01 & 0.03 & $\underline{0.02}$ & 0.09 & 0.09 \\
\hline $\begin{array}{l}\text { Distance to } \\
\text { stream }\end{array}$ & 0.11 & 0.08 & $\underline{0.02}$ & $\underline{0.02}$ & 0.07 & 0.08 & 0.33 & \\
\hline AM-trees & 0.47 & 0.41 & 0.53 & 0.46 & 0.89 & & 0.81 & \\
\hline ECM-trees & 0.08 & 0.06 & $\underline{0.02}$ & $\underline{0.01}$ & 0.63 & & 0.33 & \\
\hline \multicolumn{9}{|l|}{ WS7 vs WS13 } \\
\hline & $\begin{array}{c}\text { Full } \\
\text { Model }\end{array}$ & $\begin{array}{l}\text { Reduced } \\
\text { Model }\end{array}$ & $\begin{array}{c}\text { Full } \\
\text { Model }\end{array}$ & $\begin{array}{c}\text { Reduced } \\
\text { Model }\end{array}$ & $\begin{array}{c}\text { Full } \\
\text { Model }\end{array}$ & $\begin{array}{l}\text { Reduced } \\
\text { Model }\end{array}$ & Full Model & $\begin{array}{c}\text { Reduced } \\
\text { Model }\end{array}$ \\
\hline AIC & 301.7 & 319 & 171.3 & 171.6 & 62 & 54.3 & -16 & -34.4 \\
\hline $\begin{array}{l}\text { Watershed } \\
\text { (WS) }\end{array}$ & $\underline{0.001}$ & $\leq .0001$ & 0.07 & $\underline{0.05}$ & $\underline{0.02}$ & $\underline{0.01}$ & 0.10 & $\underline{0.04}$ \\
\hline $\begin{array}{l}\text { Overstory } \\
\text { Maple (M) }\end{array}$ & 0.43 & 0.42 & 0.38 & 0.38 & 0.91 & 0.93 & 0.6 & 0.55 \\
\hline$W S \times M$ & $\underline{0.03}$ & $\underline{0.01}$ & 0.05 & $\underline{0.03}$ & 0.82 & 0.87 & 0.25 & 0.13 \\
\hline Slope & 0.83 & & 0.04 & 0.03 & 0.10 & 0.08 & 0.44 & 0.18 \\
\hline $\mathrm{DBH}$ & 0.76 & & 0.42 & 0.30 & 0.14 & 0.06 & 0.13 & $\underline{0.04}$ \\
\hline Tree Cover & 0.84 & & 0.12 & 0.06 & 0.20 & 0.16 & 0.25 & 0.33 \\
\hline Aspect & 0.64 & 0.35 & 0.09 & $\underline{0.04}$ & 0.35 & 0.33 & 0.91 & \\
\hline $\begin{array}{c}\text { Distance to } \\
\text { stream }\end{array}$ & 0.67 & & 0.96 & & 0.88 & & 0.54 & \\
\hline AM-trees & 0.59 & 0.43 & 0.93 & & 0.78 & & 0.42 & \\
\hline ECM-trees & 0.75 & & 0.66 & & 0.29 & 0.28 & 0.15 & 0.15 \\
\hline \multicolumn{9}{|l|}{ WS10 vs WS13 } \\
\hline & $\begin{array}{c}\text { Full } \\
\text { Model }\end{array}$ & $\begin{array}{c}\text { Reduced } \\
\text { Model }\end{array}$ & $\begin{array}{c}\text { Full } \\
\text { Model }\end{array}$ & $\begin{array}{c}\text { Reduced } \\
\text { Model }\end{array}$ & $\begin{array}{c}\text { Full } \\
\text { Model }\end{array}$ & $\begin{array}{c}\text { Reduced } \\
\text { Model }\end{array}$ & Full Model & $\begin{array}{c}\text { Reduced } \\
\text { Model }\end{array}$ \\
\hline AIC & 295 & 309.6 & 179.5 & 174.8 & 70.5 & 51.3 & -11.3 & -29.6 \\
\hline $\begin{array}{l}\text { Watershed } \\
\text { (WS) }\end{array}$ & 0.26 & 0.21 & 0.68 & 0.38 & 0.20 & 0.21 & 0.16 & 0.19 \\
\hline $\begin{array}{l}\text { Overstory } \\
\text { Maple (M) }\end{array}$ & 0.19 & 0.14 & 0.22 & 0.13 & 0.23 & 0.32 & 0.45 & 0.50 \\
\hline WS $\times M$ & $\underline{0.05}$ & $\underline{0.04}$ & 0.19 & 0.15 & 0.42 & 0.58 & $\underline{0.02}$ & $\underline{0.02}$ \\
\hline Slope & $\overline{0.67}$ & & 0.93 & & 0.59 & & $\overline{0.44}$ & \\
\hline $\mathrm{DBH}$ & 0.40 & & 0.83 & & 0.11 & 0.14 & 0.01 & 0.009 \\
\hline Tree Cover & 0.17 & 0.24 & 0.73 & 0.24 & 0.31 & & $\overline{0.09}$ & $\overline{0.10}$ \\
\hline Aspect & $\underline{0.04}$ & $\underline{0.02}$ & 0.65 & $\underline{0.02}$ & 0.19 & 0.34 & $\underline{0.01}$ & $\underline{0.007}$ \\
\hline $\begin{array}{l}\text { Distance to } \\
\text { stream }\end{array}$ & $\underline{0.02}$ & $\underline{0.03}$ & 0.56 & $\underline{0.03}$ & 0.43 & & 0.08 & 0.09 \\
\hline $\begin{array}{l}\text { AM-trees } \\
\text { ECM-trees }\end{array}$ & $\begin{array}{l}0.42 \\
0.37\end{array}$ & & $\begin{array}{l}0.45 \\
0.78\end{array}$ & 0.23 & $\begin{array}{l}0.14 \\
0.70\end{array}$ & 0.10 & $\begin{array}{l}0.09 \\
0.73\end{array}$ & 0.10 \\
\hline
\end{tabular}

\footnotetext{
Bold font $=\mathrm{P} \leq 0.1$, Underlined bold font $=\mathrm{P} \leq 0.05$
} 
WS3 vs WS7: Effects of fertilization and overstory maple species

In the comparison of the two watersheds with younger stands, watershed (WS) and the watershed $\times$ overstory maple interactions $(\mathrm{WS} \times \mathrm{M})$ were statistically significant explanatory variables for most herb characteristics but overstory maple species (M) as a main effect was not. Herb cover overall tended to be lower in the fertilized watershed (WS3) than the unfertilized watershed (WS7) (P=0.09). Cover tended to be greater under sugar maples than red maples in the fertilized watershed with an opposite pattern in the unfertilized watershed (WS $\times M P=0.07)$ (Figure 8A). This pattern was also observed for species richness (WS $\mathrm{P}<0.0001$ and $\mathrm{WS} \times \mathrm{M}$ $\mathrm{P}=0.01$ ) (Figure 8B)). Twenty-three herb layer species found in the unfertilized watershed were absent from the fertilized watershed (with four species absent in WS7 but present in WS3). Most of these 23 species in WS7 had low relative over (on average 0.08\%) (Table A3). ShannonWiener diversity was lower in the fertilized watershed than the unfertilized watershed when averaged across maple species (WS $\mathrm{P}<0.0001)$ and tended to be lower underneath red maples compared to sugar maples in WS3 but not WS7 (WS $\times$ M P=0.09) (Figure 8C). Evenness overall was lower in the fertilized watershed than in the unfertilized watershed (WS $P=0.02$ ) and there was no WS $\times$ M interaction (P>0.05) (Figure 8D). Analyses of individual herb species showed that cover of three species varied with watershed or overstory maple species. Cover of Viola spp. and jack-in-the-pulpit (Arisaema triphyllum) was significantly lower in WS3 than in WS7 (WS P=0.001 and WS P=0.003, respectively). The cover of New York fern (Thelypteris noveboracensis) was greater beneath red maples than sugar maples in WS3 with an opposite pattern in WS7 (WS×M P=0.002) (Figure 7). 
WS3 vs WS7: Effect of abiotic and biotic variables

Various environmental factors explained significant variation in herb characteristics, but with independent factors being less consistent between diversity indices than WS, M, and WS $\times$ M (Table 2). Richness and diversity decreased with increasing distance from the stream $(P=0.02$ and $P=0.07)$. Richness and diversity decreased with increasing slope steepness $(P=0.01$ and $P=0.02)$. Richness, diversity and evenness tended to increase with increasing aspect code (i.e. aspect changing from southwest toward northeast) $(P=0.01, P=0.02, P=0.09$, respectively). Species richness decreased as the basal area of ECM-associated neighbor trees increased $(\mathrm{P}=0.01)$ (Table 2).

WS7 vs WS13: Effects of stand age and overstory maple species

In comparison of the two watersheds with different stand age, watershed (WS) and the watershed $\times$ overstory maple interactions $(\mathrm{WS} \times \mathrm{M})$ were statistically significant explanatory variables for most of the herb characteristics, but overstory maple (M) as a main effect was not. Herb cover was greater in the younger watershed (WS7) than in the older watershed (WS13) (WS $\mathrm{P}=0.001)$. Cover was higher under sugar maples than under red maples in the older watershed, with an opposite pattern in the younger watershed (WS $\times \mathrm{M} \mathrm{P}=0.03$ ) (Figure 8E). Species richness tended to be greater in the younger watershed than in the older watershed (WS $\mathrm{P}=0.07)$. Richness was greater under sugar maples than under red maples in the older watershed, with an opposite pattern in the younger watershed (WS $\times$ M P=0.05) (Figure 8F). Diversity and evenness were higher in the younger watershed (WS $P=0.02$ and $P=0.04$ ) than the older watershed and did not vary by overstory maple species $(\mathrm{WS} \times \mathrm{M} P>0.05)$ (Figure $8 \mathrm{G}, 8 \mathrm{H})$ (Table 2). Considering individual understory species, the cover of red maple seedlings was greater beneath sugar maples than red maples in both watersheds ( $\mathrm{P}=0.0003)$ (Figure 7). 
WS7 vs. WS13: Effects of abiotic and biotic variables

Environmental factors, such as slope, aspect, and $\mathrm{DBH}$, explained significant variation in herb characteristics, but with less consistency between the four herb characteristics (Table 2). Herb cover was not affected by any of the abiotic or biotic factors tested. Richness decreased as slope increased and richness increased with increasing aspect code (i.e. toward the NE aspect) $(P=0.04$ and $P=0.09$, respectively). Diversity tended to decrease as slope increased and it decreased with increasing $\mathrm{DBH}$ of the plot center tree $(\mathrm{P}=0.08$ and $\mathrm{P}=0.06)$. Evenness decreased as the DBH of the plot center trees increased $(P=0.04)$ (Table 2).

WS10 vs WS13: Effect of watershed aspect and overstory maple species

In comparison of the two watersheds with the same (older) stand age but varying watershed aspect, watershed (WS) and overstory maple species (M) were not statistically significant explanatory variables for any of the herb characteristics. Watershed $\times$ overstory maple interaction $(\mathrm{WS} \times \mathrm{M})$ was a statistically significant explanatory variable for cover and evenness. Herb cover under sugar maples was greater than under red maples in the northfacing watershed (WS13), while there was no difference between tree species in the southfacing watershed (WS10) (WS $\times$ M P=0.05) (Figure 8I). Evenness was greater under sugar than red maples in WS10, with an opposite pattern in WS13 (WS $\times$ M P=0.02) (Figure 8L). Species richness and diversity did not differ between watersheds (Figure 8J, 8K) (Table 2). Considering individual understory species, the cover of red maple seedlings was greater beneath sugar maples than red maples (M P=0.0003) (Figure 7).

WS10 vs WS13: Effect of abiotic and biotic variables

A few environmental factors explained significant variation in herb characteristics (Table 2). Herb cover and species richness increased with increasing aspect code $(P=0.04$ and $P=0.02$, respectively) and decreased with increasing distance to stream $(P=0.02$ and $P=0.03$, 
respectively). Shannon-Wiener Diversity tended to increase with increasing basal area of AM associated trees $(P=0.1)$. Evenness decreased with increasing $\mathrm{DBH}$ and aspect $(\mathrm{P}=0.009$ and $P=0.007$, respectively). As canopy cover increased, evenness increased as well $(P=0.1)$.

\section{Discussion}

The forest understory plays important roles in deciduous forests through its influence on nutrient cycling, provision of habitat, and overstory regeneration. This study evaluated understory composition beneath red and sugar maple, tree species that differ in their influences on nutrient cycling (St Clair and Lynch 2005, Abrams 1998, Lovett et al. 2004). The overstory tree species effect was studied in tandem with watershed effects and other factors that are wellknown to influence the understory. The watersheds evaluated at the Fernow Experimental Forest varied in $\mathrm{N}$ deposition level, stand age, and aspect, factors which comprise or influence the abiotic and biotic environment for understory growth (Gilliam 2006, Gilliam et al. 2016, Olivero and Hix 1998, Hawley et al. 1983). This study showed that understory communities can be affected by numerous factors, including overstory tree species, environmental factors including aspect and slope, and anthropogenic activities, such as $\mathrm{N}$ fertilization and time since last harvest.

Herb Layer Responses to Overstory Red Maple vs. Sugar Maple [H1]

This study revealed that there was no consistent response of the herb layer to the overstory tree species (i.e. no statistically significant $M$ main effect in any model), but that the herb response differed by maple species depending on the watershed. In seven of the 12 models (four herb characteristics and three watershed pairs) there was a significant effect (or trend) of the WS $\times$ M interaction, indicating that herb layer cover and diversity indices were lower under red maple relative to sugar maple in WS7 and WS13, but not in the other watersheds (Figure 8). 
Red maples and sugar maples also behave differently in terms of nitrogen cycling. Chapman et al. (2006) separated plants into nitrogen-conservative and nitrogen-extravagant groups depending on the plant species' and mycorrhizal symbionts' strategies and the environment they inhabit. Nitrogen-conservative plant traits include (a) high levels of mycorrhizal colonization, (b) reliance on mycorrhizal fungi for nutrient uptake, (c) ability to access organic nitrogen, and (d) production of low quality litter. Soils beneath nitrogen-extravagant plants are more prone to nitrogen leaching and these plants (a) do not support high levels of mycorrhizal colonization, (b) are unable to access organic N, and (c) produce high quality litter (Chapman et al. 2006). On native soil, red maple compared to sugar maple has been shown to have higher levels of mycorrhizal colonization and photosynthesis, with higher photosynthesis likely being a consequence of the higher mycorrhizal colonization as this symbiosis can increase nutrient uptake and water use efficiency in plants (Caravaca et al. 2003). The quality and quantity of tree litter also differs between red maples and sugar maples. Soils beneath sugar maple have significantly less forest floor biomass, a lower C:N ratio in the mineral soil (Finzi et al. 1998, Vitousek et al. 1982), and significantly more soil calcium than under the red maples (Vitousek et al. 1982). Thus, red maple demonstrates nitrogen-conservative traits and sugar maples nitrogen-extravagant traits.

Sugar maples are associated with soils with higher rates of nitrification and nitrate production than red maples (Peterjohn et al. 2015). Being highly mobile in soil, nitrate may be easily accessible to understory plants, but also more susceptible to leaching (Boudsocq et al. 2012). The process of nitrate production (nitrification) slightly decreases the $\mathrm{pH}$ of the soil, resulting in increased concentrations of cations in soil solution. Once in soil solution, increased mobility of cations, such as calcium is increased (Peterjohn et al. 1996). Dijkstra (2002) showed that calcium availability varied beneath tree species, with mineral soil calcium being highest under sugar maples and lowest under red maples among all species studied. Vitousek et al. 
(1982) also found that sugar maples had more than double the amount of calcium availability in the soil than red maples.

In sum, the two maple species can affect the spatial pattern of nutrient availability, and thus influence the abundance and possibly diversity of the understory. The higher availability of nitrogen and calcium beneath sugar maples creates an environment that better supports a higher abundance of understory plants ("sugar maple effect") as seen in WS3 and WS13 (Figure 10). This study indicates that a "sugar maple effect" may not manifest under some conditions as seen in in the younger reference watershed (WS7) and the older reference watershed with a southerly watershed aspect (WS10). While this study did not investigate causation, it may be possible that, in the absence of fertilization, a sugar maple effect is detectable under the intermediate levels of soil fertility of WS13, but not under the more fertile conditions of WS7 (as evidenced by relatively high streamwater nitrate concentrations, Table 3) or under conditions of low soil fertility/moisture of WS10 (as evidenced by relatively low streamwater nitrate concentrations, Table 3). Under conditions of high external $\mathrm{N}$ inputs in WS3, sugar maple may be able to buffer against nutrient imbalances following excessive nitrate leaching (Table 3 ) by relatively high rates of calcium mineralization. 

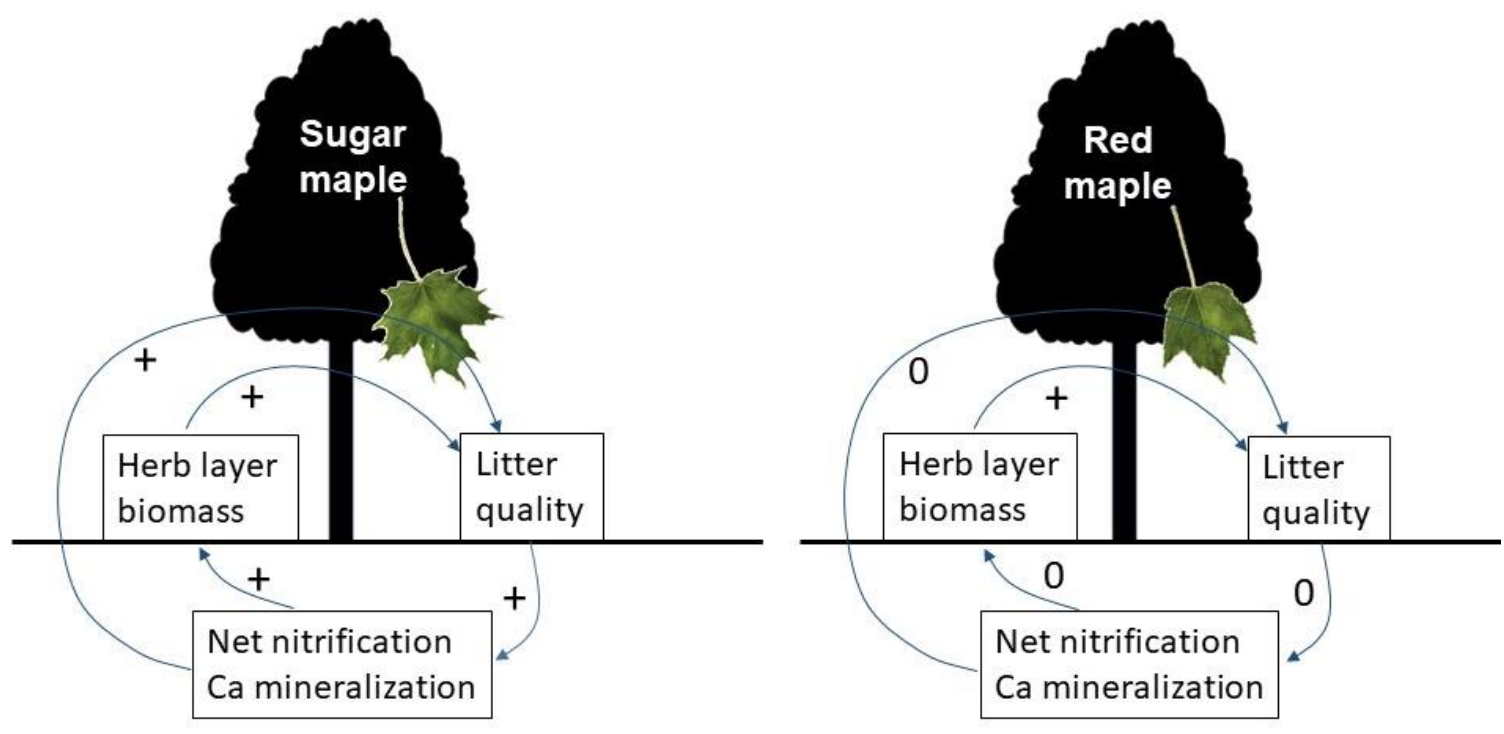

Figure 10. Conceptual diagram of how sugar and red maple may affect herb layer biomass through neutrally $(0)$ or positively $(+)$ influencing soil nitrate and calcium availability.

Herb Layer Responses to Fertilization: WS3 vs WS7 [H2]

In this study, the herbaceous layer cover and diversity indices were consistently negatively affected by $\mathrm{N}$ amendments to watershed 3 compared to its unfertilized reference watershed (WS7). As the applied fertilizer is ammonium sulfate, changes in the understory may reflect direct responses to $\mathrm{NH}_{4}{ }^{+}$or concomitant changes in soil properties (i.e. soil acidification, calcium loss), and indirect responses via competitive exclusion from nitrophilic species. These effects may be modified by the dominant tree species, which differentially influence $\mathrm{N}$ and $\mathrm{Ca}$ cycling (Dijkstra 2002, Abrams 1998).

Diversity indices $(\mathrm{S}, \mathrm{H}, \mathrm{J})$ were lower in the fertilized than unfertilized watershed. This pattern is in agreement with the $\mathrm{N}$ homogenization hypothesis (Gilliam 2006), stating that, as an ecosystem shifts from $\mathrm{N}$ limitation to $\mathrm{N}$ saturation, species richness decreases from the displacement of N-efficient species by nitrophilic species. In this study, as in the study of Gilliam 
et al. (2016), N-efficient species were displaced by species like Rubus spp., altering community composition and decreasing biodiversity. The $\mathrm{N}$ homogenization hypothesis also states that the response time of the herbaceous layer to fertilization will depend on ambient $\mathrm{N}$ deposition. For example, an environment with low $\mathrm{N}$ would react more quickly to additional $\mathrm{N}$ than an environment with high $\mathrm{N}$. As sugar maples are known to be associated with higher $\mathrm{N}$ availability than red maples (Peterjohn et al. 2015), the vicinity of sugar maples could potentially delay the negative effects of fertilization on understory richness, diversity and evenness. However, since fertilization began almost 30 years ago, the current "sugar maple effect" is likely due to sugar maple buffering against nutrient imbalances (Figure 10).

This study provided additional data to the research by Gilliam et al. (2016) comparing herb layer characteristics in WS4 (similar to WS10NS13) and fertilized WS3 during the first 25 years of $\mathrm{N}$ fertilization. In their study, there was an increase in cover in the fertilized young watershed (WS3) in comparison to the older unfertilized watershed (WS4). In our study, the younger but unfertilized watershed (WS7) also had a higher cover than the older watershed (WS13), indicating that the findings of Gilliam et al. (2016) may also represent an age effect rather than fertilization effect and, thus, highlighting the need for careful selection of reference watersheds in case studies.

Herb Layer Responses to Land Use History (Stand Age): WS7 vs WS13 [H3]

Herb cover and diversity indices $(\mathrm{S}, \mathrm{H}, \mathrm{J})$ were consistently greater in the younger watershed (WS7) compared to the older watershed (WS13). The results of this study are in agreement with Bormann and Likens (1979), who noted greater diversity in recently disturbed stands (25-75 years since disturbance) relative to mature stands in the Hubbard Brook Experimental Forest in New Hampshire. Small and McCarthy (2005) found that the herb layer had greater richness and abundance in a 7-year old stand than in a 125-year old stand in Athens County, Ohio. One reason for these pattern is that younger stands tend to have 
increased spatial heterogeneity and increased resource availability compared to mature stands (Getzin et al. 2008). Although this study did not detect any differences in light availability by measuring crown openness with a densiometer, WS7 and WS13 may have varied in light quality because of differing crown structure (Peterjohn 2017). However, the two watersheds did vary in soil nutrient resources. Streamwater nitrate and calcium export, reflecting high availability of these ions to plants, were higher in the younger watershed (WS7) than in the older watershed (WS13) (Table 3). Assuming that streamwater chemistry of reference watersheds reflects watershed fertility (as opposed to tree composition, see Peterjohn et al. 2015), and since both watersheds are similar in other characteristics, it is likely that WS7 supported higher cover and herb layer diversity than WS13 due to higher soil nutrient levels as a result of more recent disturbance. In contrast, in fertilized WS3, where excess N (Table 3) could theoretically support the highest herb layer cover (out of all watersheds in the study), this potential for highest cover may have been counterbalanced by detrimental Ca losses due to increased nitrate leaching.

Table 3. Average streamwater nutrient concentrations in the Fernow Experimental Forest over a 30-year period (1983-2015) (from Peterjohn 2017). The linear regression between streamwater nitrate and calcium yielded an $R^{2}=0.99(n=4)$.

\begin{tabular}{ccccccc}
\hline $\begin{array}{c}\text { Watershed } \\
\text { ID }\end{array}$ & $\begin{array}{c}\text { Calcium } \\
\text { Export } \\
(\mathbf{m g} / \mathbf{L})\end{array}$ & SD & $\begin{array}{c}\text { Nitrate } \\
\text { Export } \\
(\mathbf{m g} / \mathbf{L})\end{array}$ & SD & Treatment & $\begin{array}{c}\text { Stand } \\
\text { Age } \\
(\mathbf{y r})\end{array}$ \\
\hline 3 & 2.8 & 0.21 & 8.5 & 1.14 & Fertilization & $\sim 50$ \\
7 & 2.07 & 0.14 & 4.6 & 0.67 & Reference & $\sim 50$ \\
13 & 1.76 & 0.18 & 1.96 & 0.63 & Reference, North Aspect & $\sim 110$ \\
10 & 1.60 & 0.20 & 0.83 & 0.32 & Reference, South Aspect & $\sim 110$ \\
& & & & & &
\end{tabular}


Herb Layer Responses to Watershed Aspect: WS13 vs WS10 [H4]

For the two reference watersheds, there was no main effect of WS (i.e. watershed aspect) explaining herb characteristics. Herb cover was higher under sugar maples than red maples in WS13 and cover under sugar maple in WS13 was higher than cover under either maple species in WS10 (Figure 8I). This difference in cover was in part due to the higher abundance of nitrophilic Rubus spp. under sugar maple than under red maple in WS13 or either maple in WS10 (Figure 7). While species richness and diversity of the understory did not differ between watersheds and overstory maple species, evenness was higher beneath sugar maples in WS10 in comparison to red maples with an opposite pattern in WS13. The lack of a watershed effect between the two reference watersheds supports the assumption that FEF watersheds in close proximity are similar enough that, while pseudoreplicated, differences found in comparisons between watersheds (WS3 vs WS7, WS7 vs WS13) are likely due to the treatment (i.e. fertilization and stand age, respectively).

While not a focus of this study, the differences in overall watershed aspect between WS13 and WS10 could possibly explain the differences in relative importance values for sugar maples and red maples found in WS13 and WS10 by Peterjohn et al. (2015). WS13 has a relative importance value for sugar maple of $23 \%$ and red maple of $11 \%$. In contrast, WS10 has a relative importance value for sugar maple of $7 \%$ and red maple of $22 \%$. The contrasting importance of maple species in these watersheds may be a response to soil moisture availability. Red maples grew better in hotter and drier soil environments and took up more ammonium than sugar maples in a soil warming experiment at Harvard Forest (Butler et al. 2017). South-facing WS10 could be expected to have higher soil temperature and lower soil moisture, than the north-facing WS13, with WS10 thus potentially providing an advantage for red maple. 
Influence of other environmental factors

At the plot-level, slope steepness and aspect (WS3 vs WS7 and WS7 vs WS13) or plot aspect alone (WS13 vs WS10) explained significant variability of two or three herb characteristics (P $\leq 0.1$, Table 2$)$ in each watershed pair with lower values on steeper slopes and in plots with lower aspect codes. The influence of these abiotic factors (via soil moisture) on vegetation has long been established and are not surprising in the mountainous terrain of the Fernow Experimental Forest.

Distance to stream, tree cover, and DBH of plot center trees also explained variation in some herb characteristics in this study. Increasing distance between plot center and stream decreased species richness and diversity in two of the watershed pairs, potentially due to reduced light availability or lower soil moisture, reducing diversity (Guo et al. 2019). Canopy cover and DBH of the plot-center maple mostly affected evenness. Increasing canopy cover generally increased evenness in watershed pairs WS7 vs WS13 and WS10 vs WS13. Increasing DBH decreased evenness in WS7 and WS13 and WS13 vs WS10. Since these effects were mostly statistical trends, they are not further discussed.

\section{Mycorrhizal Associations}

In this study, different mycorrhizal association of neighboring trees affected the younger watershed pair (WS3 and 7) than the older reference watershed pair (WS10 and 13) but with a similar outcome. In the younger watershed pair, an increase of basal area of ECM trees near herb sampling quadrats decreased understory species richness (and cover as a trend); in the older reference watershed pair, the increase of basal area of AM trees increased diversity and evenness. In this study, neighboring trees, growing on average $4 \mathrm{~m}$ away from the plot-center maple (range 0.5-11.6 m) could influence the litter quality in the study plots. Trees associated with ectomycorrhizal fungi (ECM) grow more slowly and their litter breaks down more slowly 
than that from arbuscular mycorrhizal (AM) trees (Cornelissen et al. 2001). This differing rate in nutrient turnover may affect the herbaceous layer by impacting nutrient access to the understory (Chapman et al. 2005).

\section{Summary \& Conclusions}

In the watersheds evaluated at the Fernow Experimental Forest, overstory tree species, $\mathrm{N}$ deposition level, stand age, and other environmental factors, but not watershed aspect, influenced herb layer characteristics. This study demonstrated 1) a sugar maple effect, i.e. sugar maple having a positive effect on understory cover, at intermediate levels of soil fertility (in reference watersheds) and in an $\mathrm{N}$-fertilized watershed by improving the nutrient microenvironment for herb layer plants, 2) that long-term $\mathrm{N}$ enrichment can reduce ecosystem biodiversity by favoring nitrophilic plant species, and 3) that herb layer characteristics can be influenced by stand age, with more recent disturbance being reflected in higher herb layer abundance and diversity. The lack of a "watershed" effect in the comparison of the two older reference watersheds is a strong indicator that differences found between the fertilized and unfertilized watersheds and between the watersheds with younger and older stands are due to the fertilization and stand age rather than site effects.

While lower herb layer cover and diversity indices in older relative to younger stands may be part of the natural successional trajectory in forests recovering from disturbance, lower herb layer cover and diversity in the $\mathrm{N}$-fertilized watershed indicates that anthropogenic activity may have fundamentally altered the overall structure and function of the eastern deciduous forest over the past decades of high atmospheric $\mathrm{N}$ deposition. Looking into the future, as maple species are shifting in abundance in the eastern United States (Fei and Steiner 2007), concomitant change in the understory can be expected along with changes in ecosystem function due to feedbacks between diversity and productivity. Given the urgent need to adapt forest management to meet the challenges of climate change and other anthropogenic 
influences, this study justifies further examination of tree-herb layer interactions for a wider range of tree species, $\mathrm{N}$-deposition levels and stand ages in future studies. 


\section{Literature Cited}

Abrams, M. D. 1998. The red maple paradox. Bioscience 48:355-364.

Adams, M. B., D. R. DeWalle, and J. L. Hom. 2006. The Fernow watershed acidification study. Springer, Dordrecht

Adams, M. B., P. J. Edwards, F. Wood, and J. N. Kochenderfer. 1993. Artificial watershed acidification on the Fernow Experimental Forest, USA Journal of Hydrology 150:505519.

Adams, M. B., J. N. Kochenderfer, and P. J. Edwards. 2007. The Fernow watershed acidification study: ecosystem acidification, nitrogen saturation and base cation leaching. Water, Air, \& Soil Pollution: Focus 7:267-273.

Adams, M. B., J. N. Kochenderfer, F. Wood, T. R. Angradi, and P. Edwards. 1994. Forty years of hydrometeorological data from the Fernow Experimental Forest, West Virginia. Forest Service General Technical Report (Final). PB-94-173655/XAB; FSGTR-NE--184 United States, ; Forest Service, Radnor, PA (United States). Northeastern Forest Experiment Station.

Adams, M. B. E., Pamela J.; Ford, W. Mark; Schuler, Thomas M.; Thomas-Van Gundy, Melissa; Wood, Frederica. 2012. Fernow Experimental Forest: research history and opportunities. USDA Forest Service:26.

Aerts, R. and F. S. Chapin. 2000. The mineral nutrition of wild plants revisited: A re-evaluation of processes and patterns. Pages 1-67 in A. H. Fitter and D. G. Raffaelli, editors. Advances in Ecological Research, Vol 30.

Allen, E. B., M. F. Allen, D. J. Helm, J. M. Trappe, R. Molina, and E. Rincon. 1995. Patterns and regulation of mycorrhizal plant and fungal diversity. Plant and Soil 170:47-62.

Aubertin, G. M. and J. H. Patric. 1974. Water quality after clearcutting a small watershed in West Virginia. Journal of Environmental Quality 3:243-249.

Barbosa, P. and V. A. Krischik. 1987. Influence of alkaloids on feeding preference of eastern deciduous forest trees by the gypsy moth Lymantria dispar. American Naturalist 130:5369.

Begon, M., J. L. Harper, and C. R. Townsend. 1996. Ecology: individuals, populations, and communities, 3rd edition. Blackwell Publishing, Berlin, Germany.

Bennie, J., B. Huntley, A. Wiltshire, M. O. Hill, and R. Baxter. 2008. Slope, aspect and climate: spatially explicit and implicit models of topographic microclimate in chalk grassland. Ecological Modelling 216:47-59.

Bobbink, R., K. Hicks, J. Galloway, T. Spranger, R. Alkemade, M. Ashmore, M. Bustamante, S. Cinderby, E. Davidson, F. Dentener, B. Emmett, J. W. Erisman, M. Fenn, F. Gilliam, A. Nordin, L. Pardo, and W. De Vries. 2010. Global assessment of nitrogen deposition effects on terrestrial plant diversity: a synthesis. Ecological Applications 20:30-59. 
Bormann FH Likens GE . 1979. Pattern and process in a forested ecosystem. New York: Springer-Verlag.

Boudsocq, S., A. Niboyet, J. C. Lata, X. Raynaud, N. Loeuille, J. Mathieu, M. Blouin, L. Abbadie, and S. Barot. 2012. Plant preference for ammonium versus nitrate: a neglected determinant of ecosystem functioning? American Naturalist 180:60-69.

Box, E. O., B. N. Holben, and V. Kalb. 1989. Accuracy of the AVHRR vegetation index as a predictor of biomass, primary productivity and net $\mathrm{CO}^{2}$ flux. Vegetation 80:71-89.

Broeckling, C. D., A. K. Broz, J. Bergelson, D. K. Manter, and J. M. Vivanco. 2008. Root exudates regulate soil fungal community composition and diversty. Applied and Environmental Microbiology 74:738-744.

Brussaard, L., P. C. de Ruiter, and G. G. Brown. 2007. Soil biodiversity for agricultural sustainability. Agriculture, Ecosystems \& Environment 121:233-244.

Butler, S. M., J. M. Melillo, J. E. Johnson, J. Mohan, P. A. Steudler, H. Lux, E. Burrows, R. M. Smith, C. L. Vario, L. Scott, T. D. Hill, N. Aponte, and F. Bowles. 2012. Soil warming alters nitrogen cycling in a New England forest: implications for ecosystem function and structure. Oecologia 168:819-828.

Cantlon, J. E. 1953. Vegetation and microclimates on north and south slopes of Cushetunk Mountain, New Jersey. Ecological Monographs 23:241-270.

Carl, R. C. and E. J. B. Ralph. 1984. Correlations of understory herb distribution patterns with microhabitats under different tree species in a mixed mesophytic forest. Oecologia 62:337-343.

Carlisle, A., A. H. F. Brown, and E. J. White. 1967. The nutrient content of tree stem flow and ground flora litter and leachates in a sessile oak (Quercus Petraea) woodland. Journal of Ecology 55:615-627.

Caravaca, F., E. Diaz, J. M. Barea, C. Azcon-Aguilar, and A. Roldan. 2003. Photosynthetic and transpiration rates of Olea europaea subsp sylvestris and Rhamnus lycioides as affected by water deficit and mycorrhiza. Biologia Plantarum 46:637-639.

Chapin, F. S., K. Autumn, and F. Pugnaire. 1993. Evolution of suites of traits in response to environmental-stress. American Naturalist, The 142:78.

Chapin, F. S. 2003. Effects of plant traits on ecosystem and regional processes: a conceptual framework for predicting the consequences of global change. Annals of Botany 91:455463.

Chapin, F. S. and R. A. Kedrowski. 1983. Seasonal changes in nitrogen and phosphorus fractions and autumn retranslocation in evergreen and deciduous taiga trees. Ecology 64:376-391.

Chapman, S. K., J. A. Langley, S. C. Hart, and G. W. Koch. 2006. Plants actively control nitrogen cycling: uncorking the microbial bottleneck. New Phytologist 169:27-34. 
Cornelissen, J., R. Aerts, B. Cerabolini, M. Werger, and M. van der Heijden. 2001. Carbon cycling traits of plant species are linked with mycorrhizal strategy. Oecologia 129:611619.

Dijkstra, F. A. 2003. Calcium mineralization in the forest floor and surface soil beneath different tree species in the northeastern US. Forest Ecology and Management 175:185-194.

Driscoll, C. T., D. Whitall, J. Aber, E. Boyer, M. Castro, C. Cronan, C. L. Goodale, P. Groffman, C. Hopkinson, K. Lambert, G. Lawrence, and S. Ollinger. 2003. Nitrogen pollution in the northeastern United States: Sources, effects, and management options. Bioscience 53:357-374.

Elliott, K. J., J. M. Vose, J. D. Knoepp, B. D. Clinton, and B. D. Kloeppel. 2015. Functional role of the herbaceous layer in eastern deciduous forest ecosystems. Ecosystems 18:221236.

Fei, S. L., J. M. Desprez, K. M. Potter, I. Jo, J. A. Knott, and C. M. Oswalt. 2017. Divergence of species responses to climate change. Science Advances 3:1-9.

Fei, S. L. and K. C. Steiner. 2007. Evidence for increasing red maple abundance in the eastern United States. Forest Science 53:473-477.

Finzi, A. C., N. Van Breemen, and C. D. Canham. 1998. Canopy tree soil interactions within temperate forests: Species effects on soil carbon and nitrogen. Ecological Applications 8:440-446.

Fowells, H. A. 1975. Silvics of forest trees of the United States. U.S. Dept. of Agriculture, Forest Service, Washington.

Freschet, G. T., R. Aerts, and J. H. C. Cornelissen. 2012. A plant economics spectrum of litter decomposability. Functional Ecology 26:56-65.

Freschet, G. T., W. K. Cornwell, D. A. Wardle, T. G. Elumeeva, W. D. Liu, B. G. Jackson, V. G. Onipchenko, N. A. Soudzilovskaia, J. P. Tao, and J. H. C. Cornelissen. 2013. Linking litter decomposition of above- and below-ground organs to plant-soil feedbacks worldwide. Journal of Ecology 101:943-952.

Fu, X., F. Yang, J. Wang, Y. Di, and X. Dai. 2015. Understory vegetation leads to changes in soil acidity and in microbial communities 27 years after reforestation. Science of The Total Environment 502:280-286.

Gessner, M. O., C. M. Swan, C. K. Dang, B. G. McKie, R. D. Bardgett, D. H. Wall, and S. Hattenschwiler. 2010. Diversity meets decomposition. Trends in Ecology \& Evolution 25:372-380.

Getzin, S., T. Wiegand, K. Wiegand, and F. L. He. 2008. Heterogeneity influences spatial patterns and demographics in forest stands. Journal of Ecology 96:807-820.

Gilliam, F. S. 2006. Response of the herbaceous layer of forest ecosystems to excess nitrogen deposition. Journal of Ecology 94:1176-1191. 
Gilliam, F. S. 2007. The ecological significance of the herbaceous layer in temperate forest ecosystems. Bioscience 57:845-858.

Gilliam, F. S. 2014. The herbaceous layer in forests of eastern north America. Oxford University Press, New York, United States.

Gilliam, F. S., J. H. Billmyer, C. A. Walter, and W. T. Peterjohn. 2016. Effects of excess nitrogen on biogeochemistry of a temperate hardwood forest: Evidence of nutrient redistribution by a forest understory species. Atmospheric Environment 146:261-270.

Gilliam, F. S., N. L. Turrill, S. D. Aulick, D. K. Evans, and M. B. Adams. 1994. Herbaceious layer and soil response to experimental acidification in a central Appalachian hardwood forest. Journal of Environmental Quality 23:835-844.

Gotmark, F., H. Paltto, B. Norden, and E. Gotmark. 2005. Evaluating partial cutting in broadleaved temperate forest under strong experimental control: Short-term effects on herbaceous plants. Forest Ecology and Management 214:124-141.

Guo Yanpei, Y., C. Schob, W. Ma, A. Mohammat, and H. Liu. Increasing water availability and facilitation weaken biodiversity-biomass relationships in shrublands. Ecology 100.

Haack Robert, A. R., F. Herard, J. Sun, and J. J. Turgeon. 2010. Managing invasive populations of Asian longhorned beetle and citrus longhorned beetle: a worldwide perspective. Annual Review of Entomology 55:521-546.

Hawley, M. E., T. J. Jackson, and R. H. McCuen. 1983. Surface soil moisture variation on small agricultural watersheds. Journal of Hydrology 62:179-200.

Hepler Peter, K. P. 1989. Calcium: a central regulator of plant growth and development. Plant Cell, The 17:2142-2155.

Hooper, D. U., F. S. Chapin, J. J. Ewel, A. Hector, P. Inchausti, S. Lavorel, J. H. Lawton, D. M. Lodge, M. Loreau, S. Naeem, B. Schmid, H. Setala, A. J. Symstad, J. Vandermeer, and D. A. Wardle. 2005. Effects of biodiversity on ecosystem functioning: A consensus of current knowledge. Ecological Monographs 75:3-35.

Horsley, S. B. 1993. Role of allelopathy in hay-scented fern interference with black cherry regeneration. Journal of Chemical Ecology 19:2737-2755.

Kang, H., S. Kang, and D. Lee. 2009. Variations of soil enzyme activities in a temperate forest soil. Ecological Research 24:1137-1143.

Lapointe, L. 2001. How phenology influences physiology in deciduous forest spring ephemerals. Physiologia Plantarum 113:151-157.

Lavelle, P., C. Lattaud, D. Trigo, and I. Barois. 1995. Mutualism and biodiversity in soils. Plant and Soil 170:23-33.

Liang, J. J., M. Zhou, P. C. Tobin, A. D. McGuire, and P. B. Reich. 2015. Biodiversity influences plant productivity through niche-efficiency. Proceedings of the National Academy of Sciences of the United States of America 112:5738-5743. 
Lovett, G. M., M. A. Arthur, K. C. Weathers, and J. M. Griffin. 2010. Long-term changes in forest carbon and nitrogen cycling caused by an introduced pest/pathogen complex.

Ecosystems 13:1188-1200.

Lovett, G. M. and M. J. Mitchell. 2004. Sugar maple and nitrogen cycling in the forests of eastern North America. Frontiers in Ecology and the Environment 2:81-88.

Lovett, G. M., K. C. Weathers, and M. A. Arthur. 2002. Control of nitrogen loss from forested watersheds by soil carbon: Nitrogen ratio and tree species composition. Ecosystems 5:712-718.

McDonald JH (2014) Handbook of biological statistics, Ed 2. Baltimore: Sparky House.

Mahmood, T., W. M. Kaiser, R. Ali, M. Ashraf, and A. Gulnaz. 2005. Ammonium versus nitrate nutrition of plants stimulates microbial activity in the rhizosphere. Plant and Soil 277:233243.

Måren, I. E., S. Karki, C. Prajapati, R. K. Yadav, and B. B. Shrestha. 2015. Facing north or south: does slope aspect impact forest stand characteristics and soil properties in a semiarid trans-Himalayan valley? Journal of Arid Environments 121:112-123.

Melillo, J. M., J. D. Aber, A. E. Linkins, A. Ricca, B. Fry, and K. J. Nadelhoffer. 1989. Carbon and nitrogen dynamics along the decay continuum: plant litter to soil organic matter. Plant and Soil 115:189-198.

Moreau, D., G. Milard, and N. Munier-Jolain. 2013. A plant nitrophily index based on plant leaf area response to soil nitrogen availability. Agronomy for Sustainable Development 33:809-815.

Mudrick, D. 1994. Decomposition of leaf litter in an Appalachian forest: effects of leaf species, aspect, slope position and time. Forest Ecology and Management 68:231-250.

Muller, R. N. 1978. The phenology, growth and ecosystem dynamics of Erythronium americanum in the northern hardwood forest. Ecological Monographs 48:1-20.

Muller, R. N. and F. H. Bormann. 1976. Role of Erythronium americanum Ker. in energy flow and nutrient dynamics of a northern hardwood forest ecosystem. Science 193:11261128.

Oheimb, G. and Härdtle, W. 2009. Selection harvest in temperate deciduous forests: impact on herb layer richness and composition. Biodiversity and Conservation 18:271-287.

Ohsowski Brian, M., K. E. Dunfield, J. N. Klironomos, and M. M. Hart. 2016. Improving plant biomass estimation in the field using partial least squares regression and ridge regression. Botany / Botanique 94:501-508.

Olivero, A. M. and D. M. Hix. 1998. Influence of aspect and stand age on ground flora of southeastern Ohio forest ecosystems. Plant Ecology 139:177-187. 
Paerl, H. W., R. L. Dennis, and D. R. Whitall. 2002. Atmospheric deposition of nitrogen: implications for nutrient over-enrichment of coastal waters. Estuaries 25:677-693.

Perry, TO. 1989. Tree roots: facts and fallacies. Arnoldia 49(4):3-24.

Peterjohn, W. T., M. B. Adams, and F. S. Gilliam. 1996. Symptoms of nitrogen saturation in two central Appalachian hardwood forest ecosystems. Biogeochemistry 35:507-522.

Peterjohn, W. T. 2017. Fernow Experimental Forest Watersheds. Retrieved October 12, 2017, from http://www.as.wvu.edu/fernow/site.html

Peterjohn, W. T., M. A. Harlacher, M. J. Christ, and M. B. Adams. 2015. Testing associations between tree species and nitrate availability: Do consistent patterns exist across spatial scales? Forest Ecology and Management 358:335-343.

Pielou, E. C. 1975. Ecological diversity. Wiley, New York.

Rajaniemi, T. K. 2002. Why does fertilization reduce plant species diversity? Testing three competition-based hypotheses. Journal of Ecology 90:316-324.

Shannon, C. E. and W. Weaver. 1949. The mathematical theory of communication. University of Illinois Press, Urbana.

Small, C. J. and B. C. McCarthy. 2005. Relationship of understory diversity to soil nitrogen, topographic variation, and stand age in an eastern oak forest, USA. Forest Ecology and Management 217:229-243.

St Clair, S. B. and J. P. Lynch. 2005. Base cation stimulation of mycorrhization and photosynthesis of sugar maple on acid soils are coupled by foliar nutrient dynamics. New Phytologist 165:581-590.

Stein, L. Y. and M. G. Klotz. 2016. The nitrogen cycle. Current Biology 26:94-98.

Taylor, R. J. and R. W. Pearcy. 1976. Seasonal patterns of the carbon dioxide exchange characteristics of understory plants from a deciduous forest. Canadian Journal of Botany 54:1094-1103.

Tilman, D., J. Knops, D. Wedin, P. Reich, M. Ritchie, and E. Siemann. 1997. The influence of functional diversity and composition on ecosystem processes. Science 277:1300-1302.

Treseder, K. K. 2013. The extent of mycorrhizal colonization of roots and its influence on plant growth and phosphorus content. Plant and Soil 371:1-13.

Vezina, P. E. and M. M. Grandtner. 1965. Phenological observations of spring geophytes in Quebec. Ecology 46:869-872.

Vitousek, P. M., J. R. Gosz, C. C. Grier, J. M. Melillo, and W. A. Reiners. 1982. A comparativeanalysis of potential nitrification and nitrate mobility in forest ecosystems. Ecological Monographs 52:155-177. 
Walter, C. A., M. B. Burnham, F. S. Gilliam, and W. T. Peterjohn. 2015. A reference-based approach for estimating leaf area and cover in the forest herbaceous layer.

Environmental Monitoring and Assessment 187.

Walter, C. A., D. T. Raiff, M. B. Burnham, F. S. Gilliam, M. B. Adams, and W. T. Peterjohn. 2016. Nitrogen fertilization interacts with light to increase Rubus spp. cover in a temperate forest. Plant Ecology 217:421-430.

Walter, C. A., M. B. Adams, F. S. Gilliam, and W. T. Peterjohn. 2017. Non-random species loss in a forest herbaceous layer following nitrogen addition. Ecology 98:2322-2332.

Wu, J., Z. Liu, X. Wang, Y. Sun, and L. Zhou. 2011. Effects of understory removal and tree girdling on soil microbial community composition and litter decomposition in two Eucalyptus plantations in South China. Functional Ecology 25:921-931. 


\section{Chapter 2}

\section{Estimating Herb Layer Biomass from Cover Derived by the Hand-Area Method}

\section{Introduction}

Quantifying biomass is fundamental for understanding carbon stocks and biogeochemical cycling in terrestrial ecosystems (Luo et al. 2002). Biomass can reflect the level of productivity in ecosystems and, when assessed at species level, can easily indicate dominant plant species at a site, and thus, which species control water, nutrient, and solar resources (Fassnacht et al. 2014). The amount and distribution of plant biomass defines structure, has implication for processes, and helps maintain stability in northeastern hardwood forests. In forests, efforts have focused on estimating tree biomass and the contribution of various tissues based on measurements of DBH and basal area (Jenkins et al. 2003; Jenkins et al. 2004; Campbell et al. 1985; Martin et al. 1998). This approach has also been employed for estimating forest shrub biomass from basal diameter (Brown 1976). Less attention has been paid to the herbaceous understory due to its small biomass footprint (Gilliam 2014). However, quantifying forest herbs is important because live leaves (i.e., biomass) of typical herb layer species have high concentrations of $\mathrm{N}, \mathrm{P}, \mathrm{K}$, and $\mathrm{Mg}$ and are a major driver of nutrient cycling and nutrient availability in an ecosystem (Freshet et al. 2013).

Estimating herb biomass is common in rangeland settings. There are several "classic" techniques of estimating biomass, all requiring at least some destructive sampling and none practical when the biomass of many individual species is of interest. The harvest method determines the amount of ground vegetation at the time of harvest. This method can separate weight by species and can reflect seasonal and annual fluctuations in climate. Removal of vegetation to measure biomass prevents repeated sampling, limits long-term growth sampling, and with repeated sampling, can negatively impact the community (Ohsowski et al. 2016). 
Contemporary techniques for non-destructive biomass estimation include image analyses and frequency methods (Coulloudon et al. 1999; Bollandsas et al. 2013). Repeatability is the main advantage in these techniques, but the majority of these methods to do not quantify cover or biomass, only presence or absence. Photographs are a simple technique that requires no destructive sampling to adequately portray dominant vegetation. Rottgermann et al. (2000), established linear relationship between cover and biomass for an inland sand dune community via image analysis, which is a computerized extension of the quadrat charting method, but this can only measure the topmost vegetative layer (Dietz and Steinlein 1996).

Quadrat frequency is a very common technique that uses a quadrat sampler, generally a square or circle, that allows the user to quantify absence or presence, cover, density, and frequency of vegetation that is rooted inside the quadrat and. The dry weight rank method is type of quadrat frequency method that determines species composition by observing and ranking the three dominant species. Rank 1 corresponds to $70 \%$ composition, rank 2 to $20 \%$, and rank 3 to $10 \%$ of species composition of the quadrat. The value recorded for each species is then divided by the total of the weighted column to get a percent composition for each of the species, totaling to 100 percent (Coulloudon et al. 1999).

In contrast, simple, low-tech, yet accurate methods in estimating biomass involve relating non-destructively sampled plant cover to previously established relationships with biomass. However, few such relationships are available in the literature for forest herbs. As an exception, Gilliam and Turrill (1993) developed a universal relationship between cover and biomass for the understory at the Fernow Experimental Forest in the Appalachian Mountains of West Virginia. Expanding on the work of Giliam and Turrill (1993), this study developed linear regressions relating aboveground biomass to cover for a) 42 individual species and b) four functional groups (woody seedlings, herbs, ferns, and shrubs/vines). 


\section{Methods and Materials}

This study took place at the Fernow Experimental Forest, located near Parsons, West Virginia. In the summer of 2018, 18 circular $1-\mathrm{m}^{2}$ sampling quadrats were placed throughout each of four study watersheds; watershed 3 (WS3) watershed 7 (WS7), watershed 13 (WS13) and watershed 10 (WS10). Watersheds harbor closed-canopy eastern deciduous forests that have arisen from natural regeneration since the last major disturbance (i.e. harvest) 50 to 110 years ago; watersheds differ in fertilization level and some abiotic conditions (Table 1). Species within each sampling quadrat were identified and cover was recorded; subsequently all aboveground biomass was destructively harvested.

Table 1. Characteristics of the watersheds in the study.

\begin{tabular}{ccccccc}
\hline $\begin{array}{c}\text { Watershed } \\
\text { ID }\end{array}$ & $\begin{array}{c}\text { Area } \\
\text { (ha) }\end{array}$ & $\begin{array}{c}\text { Elevation } \\
(\mathbf{m})\end{array}$ & Aspect & $\begin{array}{c}\text { Average } \\
\text { Slope } \\
\text { (Range) } \%\end{array}$ & $\begin{array}{c}\text { Stand } \\
\text { Age } \\
(\mathbf{y r})\end{array}$ & Treatment \\
\hline 3 & 34.3 & $730-860$ & $\mathrm{~S}$ & $20.6(0-60)$ & $\sim 50$ & Fertilization \\
7 & 24.2 & $730-860$ & $\mathrm{E}$ & $25.8(0-90)$ & $\sim 50$ & Reference \\
10 & 15.2 & $695-805$ & $\mathrm{~S}$ & $33.4(0-70)$ & $\sim 110$ & Reference \\
13 & 14.2 & $610-830$ & $\mathrm{NE}$ & $35.2(0-100)$ & $\sim 110$ & Reference \\
\hline
\end{tabular}

Among all sampling quadrats, there were a total of 39 individual species plus three taxa that could only be identified to the genus level (Rubus spp., Viola spp., and Anemone spp.). Each sampling quadrat contained between one and eleven understory species. All understory species encountered in this study were less than 1 meter in height.

For each species (genus for three taxa), cover was measured as leaf area using the hand-area (HA) method (Walter et al. 2015). In brief, the HA method compares the area of a 
hand with the area of the individual leaves of a plant or species. The observer places a hand, palm side down, and fingers closed, directly above the leaves or leaflets of the species they are measuring within the sampling quadrat. The observer then determines the size of the leaf in relation to their hand, either as individual or group, until all leaf or leaflet surfaces are observed within the quadrant. A full hand is equivalent to approximately $1 \%$ of $1-\mathrm{m}^{2}$ and half a hand is $0.5 \%$ assuming the palm area is $1 \mathrm{dm}^{2}$ (Figure 1). To improve the accuracy and precision, a) observer hands were adjusted to $1 \mathrm{dm}^{2}$ by folding under the thumb and/ or fingertips depending on the actual size of the observer's hand and b) two observers independently recorded cover, and the average of the two estimates was recorded (Walter et al. 2015). After measuring the plant cover in a quadrat, all the herbs inside the quadrat were clipped at ground level, sorted by species (or genus for three taxa, see above), dried at $70^{\circ} \mathrm{C}$ for 48 hours, and weighed.

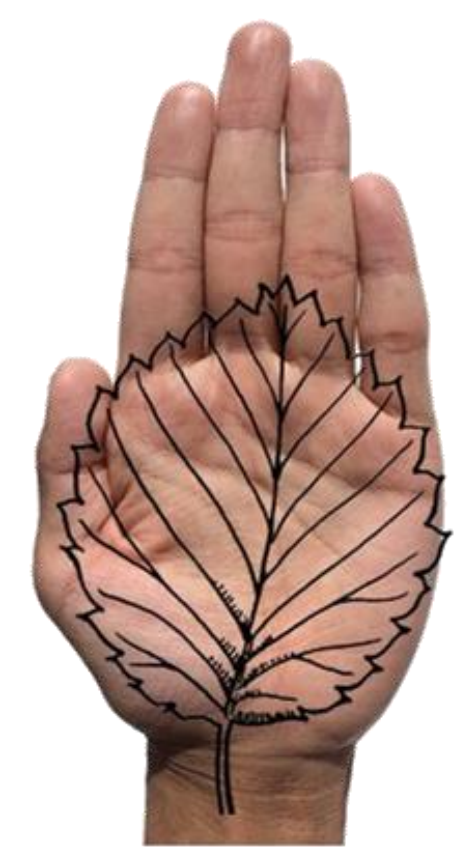

Half a hand $=0.5 \%$

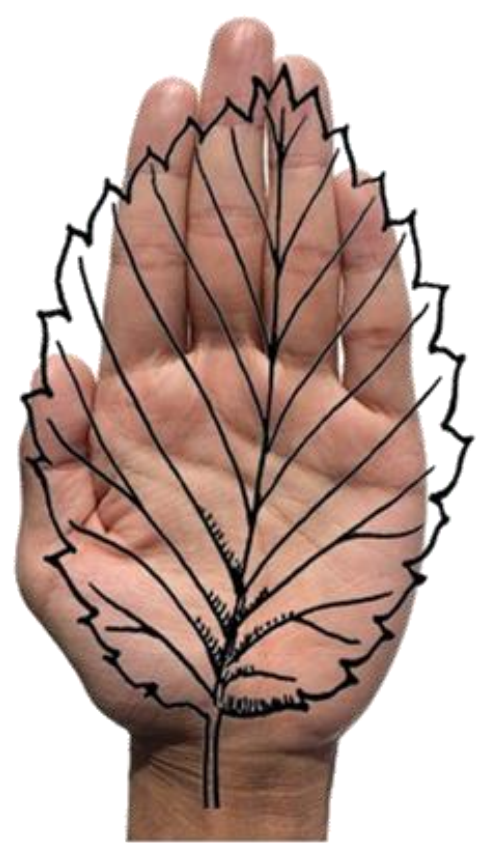

Full hand $=1 \%$

Figure 1. Visual illustration of the hand-area method. Half of a hand is equivalent to $0.5 \%$ and a full hand is equivalent to $1 \%$ of a $1-\mathrm{m}^{2}$ sampling quadrat (assuming the hand area is $1 \mathrm{dm}^{2}$ ). 


\section{Statistical methods}

A relationship of biomass to cover was developed via linear regression for each of the 42 taxa and for species combined into four groups (woody seedling, herb, fern, and shrubs/ vines) (Table 2). Residuals of each species were checked for normality and transformed using natural logarithm on both biomass and cover. Untransformed biomass and cover contained values $<1$, therefore unity was added prior to transformation. Statistical analyses were carried out using JMP and SAS software (JMP®, Version Pro 12.2, SAS Institute Inc., Cary, NC, Copyright (C2015; SAS®, Version 9.3, SAS Institute Inc., Cary, NC, Copyright (C2002-2010).

$\underline{\text { Results }}$

This study found linear relationships between the natural logarithms of cover and the dependent variable of aboveground biomass (Table 2). Of the 42 taxa collected, 22 were found in more than two sampling quadrats. The coefficient of determination $\left(R^{2}\right)$ for these species ranged from $0.49-0.90$ (Table 2 ); the $R^{2}$-value for the four most common species ranged from $0.69-0.90$ (Figure 2). When combining species into the four functional groups, the coefficient of correlation ranged from 0.69-0.78 (Table 2, Figure 3). Comparing regression parameters, the slope of the Fern group was different from the slope of the Woody Seedlings group $(\mathrm{P}=$ $<0.0001)$, the slope of the Shrubs/vines group was different from Woody Seedlings group $(P=0.006)$, and the slope of Herb group was not different from the Woody seedlings group $(P=0.69)$. There was no apparent difference in cover-biomass relationships of functional groups between the four watersheds (Figure 3). 


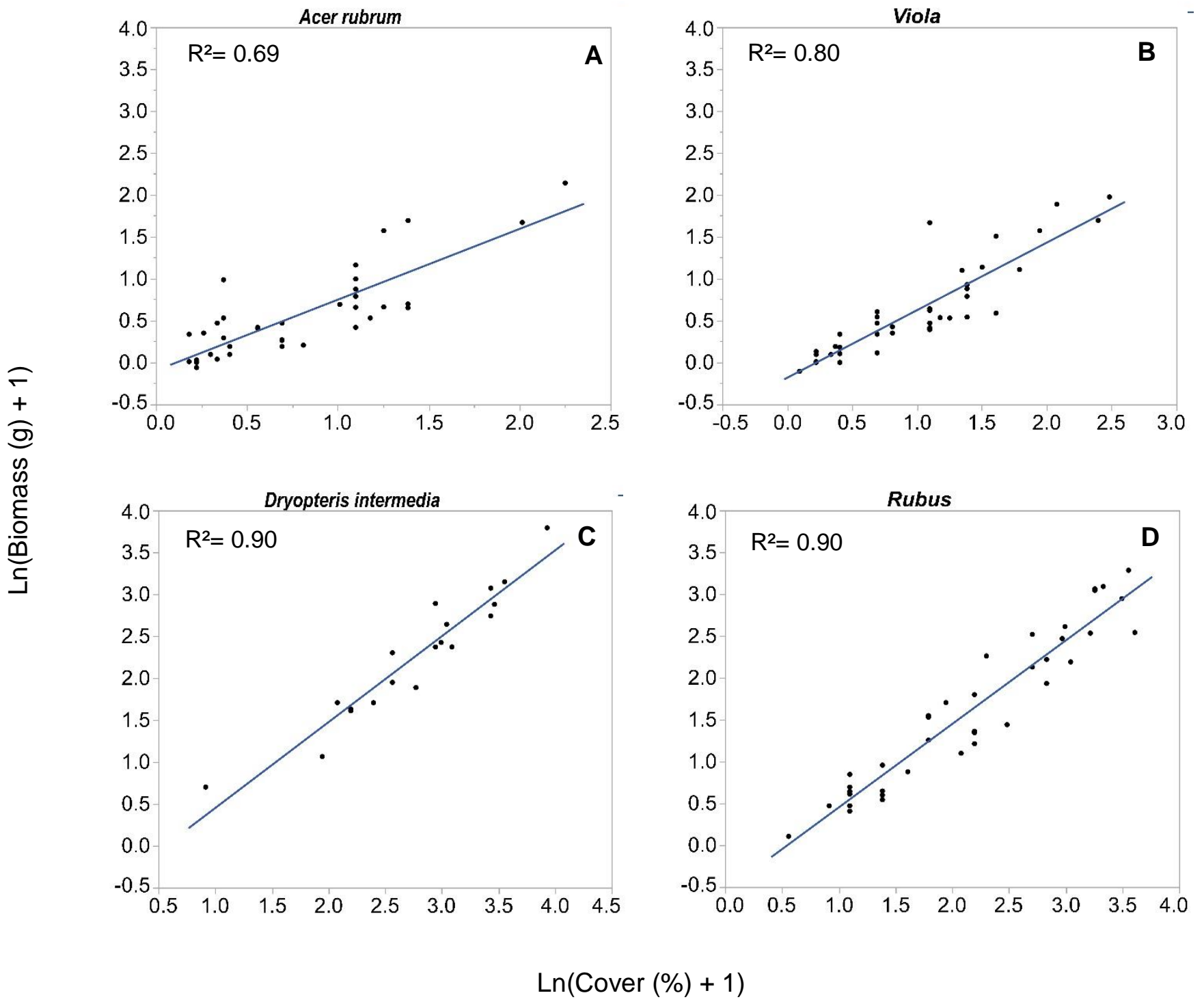

Figure 2: Relationships of log-transformed cover and biomass for the dominant herb species per functional group. A) woody seedlings: Acer rubrum (red maple), B) herbs: Viola sp. (violets), C) ferns: Dryopteris intermedia (intermediate wood fern), D) shrubs/vines: Rubus (blackberry). 


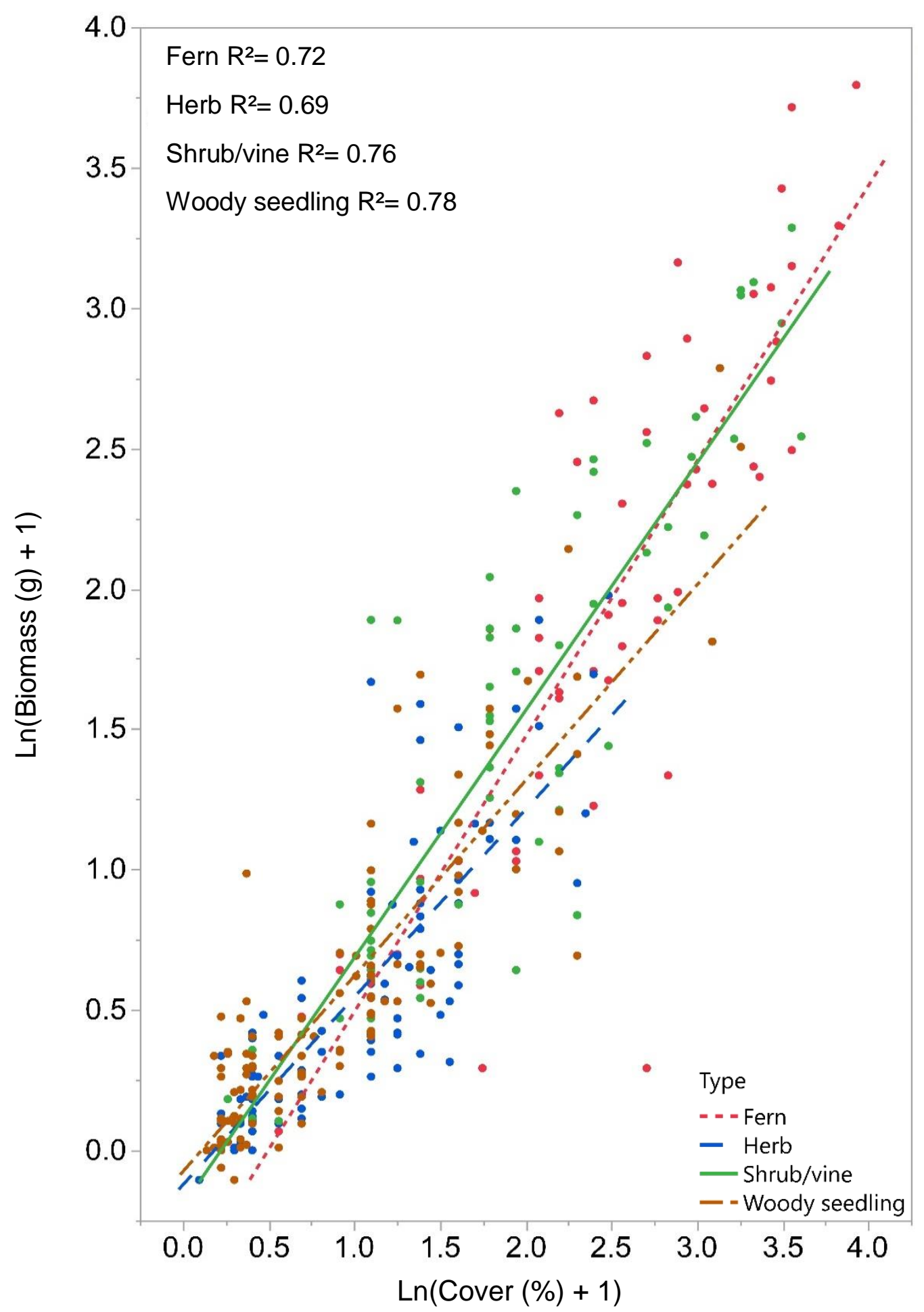

Figure 3. Linear regressions between aboveground biomass and cover (both natural-log transformed) for four functional groups of forest understory plants; woody seedlings, herbs, ferns, and shrubs/vines. 
Table 2. Regression components for estimating aboveground biomass of 42 plant species and four functional groups using the linear equation: $\ln [$ biomass $(g)+1]=a+b \ln [\operatorname{cover}(\%)+1]$.

\begin{tabular}{|c|c|c|c|c|c|}
\hline Species & $n$ & $a$ & $b$ & $R^{2}$ & SD \\
\hline \multicolumn{6}{|l|}{ Woody Seedlings } \\
\hline ash (Fraxinus americana) & 10 & 0.11 & 0.38 & 0.78 & 0.17 \\
\hline big leaf holly (llex montana) & 2 & 0.71 & 0.00 & 0.00 & 0.24 \\
\hline birch (Betula lenta) & 2 & 0.26 & 0.30 & 1.00 & 0.18 \\
\hline bitternut hickory (Carya cordiformis) & 2 & -0.10 & 0.43 & 1.00 & 0.27 \\
\hline black cherry (Prunus serotina) & $\overline{7}$ & -0.07 & 0.69 & 0.78 & 0.20 \\
\hline cucumber tree (Magnolia acuminata) & 1 & 0.09 & 0.00 & & \\
\hline Ironwood (Ostrya virginiana) & 1 & 0.99 & 0.00 & & \\
\hline red maple (Acer rubrum) & 37 & -0.09 & 0.84 & 0.69 & 0.53 \\
\hline red oak (Quercus rubra) & 18 & -0.17 & 0.79 & 0.89 & 0.73 \\
\hline sassafras (Sassafras albidum) & 2 & -0.04 & 0.20 & 1 & 0.06 \\
\hline striped maple (Acer pensylvanicum) & 25 & -0.02 & 0.59 & 0.77 & 0.54 \\
\hline sugar maple (Acer saccharum) & 11 & -0.14 & 0.74 & 0.93 & 0.45 \\
\hline tulip poplar (Liriodendron tulipifera) & 4 & -0.26 & 0.66 & 0.97 & 0.61 \\
\hline white oak (Quercus alba) & 1 & 0.02 & & & \\
\hline witch hazel (Hamamelis virginiana) & 1 & 0.11 & 0 & & \\
\hline Combined species & 126 & -0.07 & 0.69 & 0.78 & 0.25 \\
\hline \multicolumn{6}{|l|}{ Herbs } \\
\hline wintergreen (Gaultheria procumbens) & 1 & 0.33 & 0.00 & & \\
\hline bedstraw (Galium lanceolatum) & 1 & 0.48 & 0.00 & & 0.62 \\
\hline bellwort (Uvularia sessilifolia) & 3 & -0.31 & 0.81 & 0.98 & 0.48 \\
\hline chickweed (Stellaria pubera) & 23 & -0.19 & 0.83 & 0.75 & \\
\hline sweet cicily (Osmorhiza claytonia) & 1 & 1.10 & 0.00 & & 0.14 \\
\hline fairybells (Disporum lanuginsum) & 6 & 0.01 & 0.24 & 0.67 & 0.27 \\
\hline false nettle (Bohemeria cylindrica) & 2 & -0.47 & 0.97 & 1 & 0.31 \\
\hline heartleaf aster (Symphyotrichum cordifolium) & 8 & 0.02 & 0.50 & 0.64 & 0.31 \\
\hline Indian cucumber root (Medeola virginiana) & 7 & -0.01 & 0.38 & 0.69 & 0.021 \\
\hline Japanese knotweed (Reynoutria japonica) & 2 & 0.26 & 0.03 & 1 & \\
\hline nettle (Urtica dioica) & 3 & -0.18 & 0.54 & 0.80 & 0.25 \\
\hline smooth carrionflower (Smilax herbacea) & 5 & -0.19 & 0.55 & 0.78 & 0.19 \\
\hline trillium (Trillium erectum) & 1 & 0.10 & 0.00 & & 0.56 \\
\hline violets (Viola spp.) & 41 & -0.18 & 0.80 & 0.80 & \\
\hline wood anemone (Anemone spp.) & 1 & 0.92 & 0.00 & & 0.08 \\
\hline yam (Dioscorea quaternata) & 2 & 0.31 & 0.13 & 1 & \\
\hline Combined species & 107 & -0.12 & 0.66 & 0.69 & 0.26 \\
\hline \multicolumn{6}{|l|}{ Ferns } \\
\hline Christmas fern (Polystichum acrostichoides) & 14 & -0.46 & 1.16 & 0.81 & 1.01 \\
\hline cinnamon fern (Osmunda cinnamomea) & 1 & 0.69 & 0.00 & & \\
\hline hay-scented fern (Dennstaedtia punctilobula) & 13 & -0.53 & 0.85 & 0.56 & 0.81 \\
\hline intermediate fern (Dryopteris intermedia) & 20 & -0.57 & 1.02 & 0.90 & 0.74 \\
\hline lady fern (Athyrium filix-femina) & 2 & -0.0 & 0.74 & 1 & 1.38 \\
\hline New York fern (Thelypteris noveboracensis) & 7 & -0.43 & 0.78 & 0.92 & 0.79 \\
\hline Combined species & 57 & -0.48 & 0.97 & 0.72 & 0.49 \\
\hline \multicolumn{6}{|l|}{ Shrubs and Vines } \\
\hline greenbrier (Smilax rotundifolia) & 23 & 0.07 & 0.79 & 0.49 & 0.78 \\
\hline blackberry/raspberry (Rubus spp.) & 38 & -0.54 & 0.99 & 0.90 & 0.91 \\
\hline blueberry (Vaccinium pallidum) & 2 & -0.96 & 1.55 & 1 & 0.76 \\
\hline Combined species & 63 & -0.19 & 0.88 & 0.76 & 0.42 \\
\hline
\end{tabular}

SD=standard deviation 


\section{Discussion}

The results of this study show that cover can be used to estimate biomass with reasonable accuracy. Results are similar to those of the study by Gilliam and Turrill (1993) showing that biomass could be predicted from understory with the relationship: [biomass,g] = 0.18 [cover, $\%]^{1.29}$ for all species combined with an $\mathrm{R}^{2}$ of 0.71 . For comparison, in this presented study, the power relationship was [biomass, $g]=0.37$ [cover, $\%]^{1.12}\left(R^{2}=0.78\right)$. The $R^{2}$ values for all species combined are similar to the $\mathrm{R}^{2}$ values the for functional groups $(0.69-0.78$, Table 2$)$ of this study. Furthermore, Gilliam and Turrill's (1993) equation appeared to be robust across watersheds with different stand ages (WS4 with stand age of 80 years vs WS3 with stand age of 20 years at the time of their study). Visual analysis of the functional groups in the four watersheds in this study (Figure 3) confirmed their results.

Rottgermann et al. (2000) observed that a linear relationship existed between biomass and cover in inland sand dune communities, but with limitations. Herbaceous plants that grew in productive, nutrient rich sites grew larger and deviated from the linear relationship by increasing supportive plant biomass (e.g., stem) without increasing cover. Their overall coefficient of correlation for all nine species combined was 0.84 , with $\mathrm{R}^{2}$ values of individual species ranging from 0.61 to 0.95 . The species with a lower $R^{2}$ value tended to have more supportive structure and deviated from the linear relationship (Rottgermann et al. 2000).

In this study, greenbrier (Smilax rotundifolia) and hay-scented fern (Dennstaedtia punctilobula) had relatively low $R^{2}$ values ( 0.5 and 0.56 , respectively). Greenbrier samples collected varied widely in cover and weight, depending on the amount of woody stem/vines present. As greenbrier leaves are often absent due to deer browsing, the cover of horizontal stems was also included in cover measurements. While cover estimates for linear structures (stems) are more difficult than for leaves, including stem cover for vines should theoretically improve biomass prediction but needs to be verified. For both hay-scented fern and greenbrier, 
no outliers were removed so as to not reduce an already small sample size. This also contributed to the low $\mathrm{R}^{2}$ values for these two species.

Consistent cover-biomass relationships within functional groups and across environmental conditions indicate that regression equations of functional groups provide a reasonable approach to estimating the biomass of species for which no regression is available. The results of this study also showed that the relationships between cover and biomass differ between functional groups. Therefore, functional groups represent an advantage over just a single relationship for all understory plants lumped together (Brown 1976).

In sum, cover measurements for forest understory, in combination with the linear relationships provided by this study, whether for individual species or functional groups, can be used to estimate biomass in a simple and reasonably accurate manner without the need for time-consuming destructive sampling, expensive equipment, or image analysis. An expanded use of quantifying forest understory would contribute to a better understanding of the role of herb layer plants in important ecosystem processes, such as nutrient cycling, ecosystem productivity, and carbon storage. 


\section{Literature Cited}

Bollandsas, O. M., T. G. Gregoire, E. Naesset, and B. H. Oyen. 2013. Detection of biomass change in a Norwegian mountain forest area using small footprint airborne laser scanner data. Statistical Methods and Applications 22:113-129.

Brown, J. K. 1976. Predicting crown weights for 11 Rocky Mountain conifers. Working part on forest biomass, Int. Union For. Res. Organ. Cong. June 22, 1976. Oslo, Norway. Ogden, UT: USDA Forest Service, Intermountain Forest and Range Experiment Station. 13 p.

Campbell, J. S., Lieffers, V. J., Pielou, E. C. 1985. Regression equations for estimating single tree biomass of trembling aspen: assessing their applicability to more than one population. Forest Ecology and Management. 11: 283-295.

Cornelissen, J. H. C., T. V. Callaghan, J. M. Alatalo, A. Michelsen, E. Graglia, A. E. Hartley, D. S. Hik, S. E. Hobbie, M. C. Press, C. H. Robinson, G. H. R. Henry, G. R. Shaver, G. K. Phoenix, D. G. Jones, S. Jonasson, F. S. Chapin, U. Molau, C. Neill, J. A. Lee, J. M. Melillo, B. Sveinbjornsson, and R. Aerts. 2001. Global change and arctic ecosystems: is lichen decline a function of increases in vascular plant biomass? Journal of Ecology 89:984-994.

Coulloudon, B., K. Eshelman, J. Gianola, N. Habich, L. Hughes, C. Johnson, M. Pellant, P. Podborny, A. Rasmussen, B. Robles, P. Shaver, J. Spehar, and J. Willoughby. 1999. Sampling vegetation attributes- Interagency technical reference. U.S. Department of Interior, Bureau of Land Management Technical Reference 1734-4.

Dietz, H. and T. Steinlein. 1996. Determination of plant species cover by means of image analysis. Journal of Vegetation Science 7:131-136.

Fassnacht, F. E., F. Hartig, H. Latifi, C. Berger, J. Hernandez, P. Corvalan, and B. Koch. 2014. Importance of sample size, data type and prediction method for remote sensing-based estimations of aboveground forest biomass. Remote Sensing of Environment 154:102114.

Freschet, G. T., R. Aerts, and J. H. C. Cornelissen. 2012. A plant economics spectrum of litter decomposability. Functional Ecology 26:56-65.

Gilliam, F. S. and N. L. Turrill. 1993. Herbaceous layer cover and biomass in a young versus a mature stand of a central Appalachian hardwood forest. Bulletin of the Torrey Botanical Club 120:445-450.

Jenkins, J. C., D. C. Chojnacky, L. S. Heath, and R. A. Birdsey. 2003. National-scale biomass estimators for United States tree species. Forest Science 49:12-35.

Jenkins, J. C., Chojnacky, D. C., Heath, L. S., Birdsey, R. A. 2004. Comprehensive database of diameter-based biomass regressions for North American tree species. Gen. Tech. Rep. NE-319. Newtown Square, PA: U.S. Department of Agriculture, Forest Service, Northeastern Research Station. 45 p.

Luo, T. X., W. H. Li, and H. Z. Zhu. 2002. Estimated biomass and productivity of natural vegetation on the Tibetan Plateau. Ecological Applications 12:980-997. 
Martin, J., Kloeppel, B., Schaefer, T., Kimbler, D., McNulty, S. 1998. Aboveground biomass and nitrogen allocation of ten deciduous southern Appalachian tree species. Canadian Journal of Forest Research. 28:1648-1659.

Ohsowski, B. M., K. E. Dunfield, J. N. Klironomos, and M. M. Hart. 2016. Improving plant biomass estimation in the field using partial least squares regression and ridge regression. Botany / Botanique 94:501-508.

Rottgermann, M., T. Steinlein, W. Beyschlag, and H. Dietz. 2000. Linear relationships between aboveground biomass and plant cover in low open herbaceous vegetation. Journal of Vegetation Science 11:145-148.

Walter, C. A., M. B. Burnham, F. S. Gilliam, and W. T. Peterjohn. 2015. A reference-based approach for estimating leaf area and cover in the forest herbaceous layer. Environmental Monitoring and Assessment 187:657. 


\section{Appendix}

Table A1. Diameter at breast height (DBH) and location of plot-center maple species and plot elevation for each of the 72 plots in this study.

\begin{tabular}{|c|c|c|c|c|c|c|c|}
\hline WS & Site & $\begin{array}{c}\text { Maple } \\
\text { Species }\end{array}$ & $\mathrm{DBH}(\mathrm{cm})$ & Latitude & Longitude & Elevation (m) & Sampling Dates \\
\hline 3 & 1 & red & 11.9 & 39.05563 & -79.686827 & 774.72 & $6 / 25 / 2018$ \\
\hline 3 & 2 & red & 20.3 & 39.05643 & -79.686568 & 791.00 & $6 / 26 / 2018$ \\
\hline 3 & 3 & red & 20.3 & 39.05873 & -79.687191 & 821.09 & $6 / 27 / 2018$ \\
\hline 3 & 4 & red & 21.4 & 39.06014 & -79.687446 & 844.86 & $6 / 26 / 2018$ \\
\hline 3 & 5 & red & 11.1 & 39.06103 & -79.687805 & 842.89 & $6 / 26 / 2018$ \\
\hline 3 & 6 & red & 12.2 & 39.06054 & -79.68476 & 829.60 & $6 / 26 / 2018$ \\
\hline 3 & 7 & red & 10 & 39.05875 & -79.68494 & 801.37 & $6 / 25 / 2018$ \\
\hline 3 & 8 & red & 13.4 & 39.05805 & -79.685348 & 791.76 & $6 / 25 / 2018$ \\
\hline 3 & 9 & red & 18.2 & 39.05587 & -79.685122 & 775.77 & $6 / 26 / 2018$ \\
\hline 3 & 1 & sugar & 10 & 39.05522 & -79.68666 & 777.52 & 6/26/2018 \\
\hline 3 & 2 & sugar & 14.2 & 39.05663 & -79.686742 & 804.70 & $6 / 26 / 2018$ \\
\hline 3 & 3 & sugar & 13.8 & 39.05845 & -79.687258 & 821.76 & 6/27/2018 \\
\hline 3 & 4 & sugar & 19.5 & 39.06038 & -79.687458 & 829.64 & $6 / 26 / 2018$ \\
\hline 3 & 5 & sugar & 13.4 & 39.06101 & -79.687448 & 841.69 & $6 / 26 / 2018$ \\
\hline 3 & 6 & sugar & 19.9 & 39.06024 & -79.684704 & 827.64 & $6 / 25 / 2018$ \\
\hline 3 & 7 & sugar & 20.6 & 39.05878 & -79.685146 & 801.87 & $6 / 25 / 2018$ \\
\hline 3 & 8 & sugar & 23.4 & 39.0577 & -79.685536 & 785.58 & $6 / 25 / 2018$ \\
\hline 3 & 9 & sugar & 19 & 39.0559 & -79.685757 & 795.72 & $6 / 26 / 2018$ \\
\hline 7 & 1 & red & 40.7 & 39.06351 & -79.681365 & 775.42 & $6 / 21 / 2018$ \\
\hline 7 & 2 & red & 16.5 & 39.06334 & -79.683466 & 798.83 & $6 / 19 / 2018$ \\
\hline 7 & 3 & red & 10.6 & 39.06301 & -79.683226 & 794.48 & $6 / 21 / 2018$ \\
\hline 7 & 4 & red & 15 & 39.06178 & -79.683734 & 805.12 & $6 / 21 / 2018$ \\
\hline 7 & 5 & red & 19 & 39.06292 & -79.685628 & 823.73 & $6 / 21 / 2018$ \\
\hline 7 & 6 & red & 19.9 & 39.06538 & -79.684067 & 832.12 & $6 / 20 / 2018$ \\
\hline 7 & 7 & red & 11.8 & 39.06561 & -79.684033 & 824.98 & $6 / 20 / 2018$ \\
\hline 7 & 8 & red & 20.4 & 39.06447 & -79.68405 & 814.28 & $6 / 20 / 2018$ \\
\hline 7 & 9 & red & 19.3 & 39.06447 & -79.682418 & 796.32 & $6 / 20 / 2018$ \\
\hline 7 & 1 & sugar & 17 & 39.06362 & -79.681182 & 773.40 & $6 / 21 / 2018$ \\
\hline 7 & 2 & sugar & 14.5 & 39.0633 & -79.683691 & 807.91 & $6 / 19 / 2018$ \\
\hline 7 & 3 & sugar & 33.5 & 39.06288 & -79.683209 & 791.80 & $6 / 21 / 2018$ \\
\hline 7 & 4 & sugar & 17.5 & 39.06182 & -79.683399 & 802.26 & $6 / 21 / 2018$ \\
\hline 7 & 5 & sugar & 14.2 & 39.06288 & -79.685665 & 827.76 & $6 / 21 / 2018$ \\
\hline 7 & 6 & sugar & 13.5 & 39.06508 & -79.684753 & 823.15 & $6 / 20 / 2018$ \\
\hline 7 & 7 & sugar & 38.8 & 39.06561 & -79.683621 & 823.70 & $6 / 20 / 2018$ \\
\hline 7 & 8 & sugar & 12.2 & 39.06422 & -79.683568 & 797.58 & $6 / 20 / 2018$ \\
\hline 7 & 9 & sugar & 14 & 39.06402 & -79.683089 & 805.40 & $6 / 20 / 2018$ \\
\hline
\end{tabular}


Table A1 continued.

\begin{tabular}{|c|c|c|c|c|c|c|c|}
\hline WS & Site & $\begin{array}{c}\text { Maple } \\
\text { Species }\end{array}$ & $\mathrm{DBH}(\mathrm{cm})$ & Latitude & Longitude & $\begin{array}{l}\text { Elevation } \\
(\mathrm{m})\end{array}$ & $\begin{array}{l}\text { Sampling } \\
\text { Dates }\end{array}$ \\
\hline 10 & 1 & red & 17.6 & 39.05498 & -79.680481 & 747.99 & $6 / 28 / 2018$ \\
\hline 10 & 2 & red & 17.3 & 39.05541 & -79.680061 & 725.63 & 6/28/2018 \\
\hline 10 & 3 & red & 19 & 39.05625 & -79.680165 & 773.50 & $7 / 2 / 2018$ \\
\hline 10 & 4 & red & 26.5 & 39.05681 & -79.679763 & 783.52 & $7 / 2 / 2018$ \\
\hline 10 & 5 & red & 18.6 & 39.05704 & -79.680283 & 778.22 & $7 / 4 / 2018$ \\
\hline 10 & 6 & red & 35.4 & 39.05836 & -79.678755 & 791.06 & $7 / 4 / 2018$ \\
\hline 10 & 7 & red & 16.5 & 39.05775 & -79.678014 & 785.68 & $7 / 4 / 2018$ \\
\hline 10 & 8 & red & 21.2 & 39.05637 & -79.678687 & 745.19 & $7 / 4 / 2018$ \\
\hline 10 & 9 & red & 14 & 39.0554 & -79.679092 & 758.87 & $6 / 28 / 2018$ \\
\hline 10 & 1 & sugar & 30.9 & 39.05518 & -79.680156 & 736.39 & 6/28/2018 \\
\hline 10 & 2 & sugar & 14.6 & 39.05533 & -79.679933 & 741.57 & $6 / 28 / 2018$ \\
\hline 10 & 3 & sugar & 12.7 & 39.05627 & -79.679427 & 760.42 & $7 / 2 / 2018$ \\
\hline 10 & 4 & sugar & 35.5 & 39.05688 & -79.679087 & 757.54 & 7/2/2018 \\
\hline 10 & 5 & sugar & 20.1 & 39.05768 & -79.679786 & 787.91 & 7/4/2018 \\
\hline 10 & 6 & sugar & 28.1 & 39.05811 & -79.67885 & 793.11 & $7 / 4 / 2018$ \\
\hline 10 & 7 & sugar & 21 & 39.0578 & -79.678062 & 790.15 & $7 / 4 / 2018$ \\
\hline 10 & 8 & sugar & 17.3 & 39.05625 & -79.678721 & 745.43 & $7 / 4 / 2018$ \\
\hline 10 & 9 & sugar & 21.5 & 39.05556 & -79.679299 & 746.87 & $6 / 26 / 2018$ \\
\hline 13 & 1 & red & 40.6 & 39.06158 & -79.678441 & 774.05 & $7 / 3 / 2018$ \\
\hline 13 & 2 & red & 21.5 & 39.06182 & -79.679064 & 767.79 & $7 / 3 / 2018$ \\
\hline 13 & 3 & red & 31.5 & 39.06153 & -79.679415 & 758.90 & 7/3/2018 \\
\hline 13 & 4 & red & 17.5 & 39.06041 & -79.679214 & 784.02 & $7 / 3 / 2018$ \\
\hline 13 & 5 & red & 21.3 & 39.05997 & -79.682419 & 818.14 & $6 / 28 / 2018$ \\
\hline 13 & 6 & red & 14.8 & 39.06079 & -79.681116 & 787.32 & $6 / 28 / 2018$ \\
\hline 13 & 7 & red & 15.4 & 39.06133 & -79.680963 & 774.13 & $7 / 3 / 2018$ \\
\hline 13 & 8 & red & 27 & 39.0622 & -79.680698 & 759.31 & $7 / 4 / 2018$ \\
\hline 13 & 9 & red & 21.3 & 39.06275 & -79.680348 & 774.39 & $7 / 4 / 2018$ \\
\hline 13 & 1 & sugar & 68 & 39.06181 & -79.678745 & 757.39 & $7 / 3 / 2018$ \\
\hline 13 & 2 & sugar & 14.9 & 39.06181 & -79.678949 & 759.22 & 7/3/2018 \\
\hline 13 & 3 & sugar & 21 & 39.06191 & -79.679603 & 762.69 & $7 / 3 / 2018$ \\
\hline 13 & 4 & sugar & 17.5 & 39.06033 & -79.679519 & 769.52 & $7 / 3 / 2018$ \\
\hline 13 & 5 & sugar & 19.9 & 39.06007 & -79.682522 & 828.61 & $6 / 28 / 2018$ \\
\hline 13 & 6 & sugar & 21 & 39.06062 & -79.681162 & 796.00 & $7 / 3 / 2018$ \\
\hline 13 & 7 & sugar & 16.9 & 39.06166 & -79.680866 & 789.30 & $7 / 3 / 2018$ \\
\hline 13 & 8 & sugar & 12.5 & 39.06206 & -79.680811 & 784.58 & $7 / 4 / 2018$ \\
\hline 13 & 9 & sugar & 8 & 39.06264 & -79.680252 & 776.96 & $7 / 4 / 2018$ \\
\hline
\end{tabular}


Table A2. Basal area (BA) of the five nearest neighbor trees to plot-center maples, separated by arbuscular mycorrhizal (AM) and ectomycorrhizal (ECM) association. The distance of the fifthnearest tree was used to calculate the ground area (ha) by which the tree cross sectional area $\left(\mathrm{m}^{2}\right)$ was divided.

\begin{tabular}{|c|c|c|c|c|c|c|}
\hline WS & Plot & $\begin{array}{c}\text { Plot-center } \\
\text { Maple Species }\end{array}$ & $\begin{array}{c}\text { Farthest Tree } \\
\text { (meters) }\end{array}$ & Plot Area $\left(\mathrm{m}^{2}\right)$ & $\begin{array}{c}\left.\text { BA ( } \mathrm{m}^{2} / \mathrm{ha}\right) \text { of } \\
\text { AM Trees }\end{array}$ & $\begin{array}{c}\text { BA }\left(\mathrm{m}^{2} / \mathrm{ha}\right) \text { o } \\
\text { ECM Trees }\end{array}$ \\
\hline 3 & 1 & red & 4.3 & 58.06 & 0.61 & 6.11 \\
\hline 3 & 1 & sugar & 5.5 & 94.99 & 0.45 & 6.39 \\
\hline 3 & 2 & red & 3.8 & 45.34 & 12.68 & 5.24 \\
\hline 3 & 2 & sugar & 4 & 50.24 & 17.06 & 4.78 \\
\hline 3 & 3 & red & 5.5 & 94.99 & 4.33 & 10.55 \\
\hline 3 & 3 & sugar & 4.7 & 69.36 & 11.96 & 0.00 \\
\hline 3 & 4 & red & 6.8 & 145.19 & 4.67 & 0.00 \\
\hline 3 & 4 & sugar & 8 & 200.96 & 2.70 & 0.86 \\
\hline 3 & 5 & red & 4.7 & 69.36 & 3.25 & 2.80 \\
\hline 3 & 5 & sugar & 4.1 & 52.78 & 18.80 & 0.47 \\
\hline 3 & 6 & red & 11.6 & 422.52 & 0.42 & 0.12 \\
\hline 3 & 6 & sugar & 5.9 & 109.30 & 4.48 & 0.00 \\
\hline 3 & 7 & red & 5.2 & 84.91 & 10.68 & 2.13 \\
\hline 3 & 7 & sugar & 3.6 & 40.69 & 7.10 & 0.89 \\
\hline 3 & 8 & red & 5.7 & 102.02 & 1.50 & 0.00 \\
\hline 3 & 8 & sugar & 5.9 & 109.30 & 9.05 & 0.00 \\
\hline 3 & 9 & red & 5.9 & 109.30 & 5.42 & 4.31 \\
\hline 3 & 9 & sugar & 4.8 & 72.35 & 2.30 & 0.83 \\
\hline 7 & 1 & red & 5.4 & 91.56 & 0.00 & 6.19 \\
\hline 7 & 1 & sugar & 5.4 & 91.56 & 15.06 & 6.02 \\
\hline 7 & 2 & red & 7.4 & 171.95 & 6.30 & 8.98 \\
\hline 7 & 2 & sugar & 4.3 & 58.06 & 2.11 & 2.08 \\
\hline 7 & 3 & red & 4.1 & 52.78 & 11.10 & 11.05 \\
\hline 7 & 3 & sugar & 5.1 & 81.67 & 3.18 & 1.75 \\
\hline 7 & 4 & red & 5.2 & 84.91 & 7.70 & 6.51 \\
\hline 7 & 4 & sugar & 4 & 50.24 & 0.98 & 2.37 \\
\hline 7 & 5 & red & 5.7 & 102.02 & 0.63 & 1.26 \\
\hline 7 & 5 & sugar & 6.6 & 136.78 & 4.32 & 0.76 \\
\hline 7 & 6 & red & 5.4 & 91.56 & 0.58 & 1.54 \\
\hline 7 & 6 & sugar & 4.8 & 72.35 & 7.07 & 0.00 \\
\hline 7 & 7 & red & 5.5 & 94.99 & 1.78 & 0.00 \\
\hline 7 & 7 & sugar & 6.6 & 136.78 & 12.55 & 3.57 \\
\hline 7 & 8 & red & 5.6 & 98.47 & 8.99 & 6.30 \\
\hline 7 & 8 & sugar & 2.9 & 26.41 & 37.32 & 0.00 \\
\hline 7 & 9 & red & 3.2 & 32.15 & 23.07 & 0.00 \\
\hline 7 & 9 & sugar & 3.5 & 38.47 & 11.00 & 0.00 \\
\hline
\end{tabular}


Table A2 continued.

\begin{tabular}{|c|c|c|c|c|c|c|}
\hline WS & Plot & $\begin{array}{l}\text { Plot-center Maple } \\
\text { Species }\end{array}$ & $\begin{array}{l}\text { Farthest Tree } \\
\text { (meters) }\end{array}$ & Plot Area $\left(\mathrm{m}^{2}\right)$ & $\begin{array}{c}\mathrm{BA}\left(\mathrm{m}^{2} / \mathrm{ha}\right) \text { of } \mathrm{AM} \\
\text { Trees }\end{array}$ & $\begin{array}{l}\text { BA }\left(m^{2} / h a\right) \text { of } \\
\text { ECM Trees }\end{array}$ \\
\hline 10 & 1 & red & 6.2 & 120.70 & 2.30 & 0.00 \\
\hline 10 & 1 & sugar & 6.8 & 145.19 & 1.43 & 0.42 \\
\hline 10 & 2 & red & 5.2 & 84.91 & 9.70 & 19.10 \\
\hline 10 & 2 & sugar & 6.7 & 140.95 & 0.70 & 6.44 \\
\hline 10 & 3 & red & 7.3 & 167.33 & 0.92 & 15.51 \\
\hline 10 & 3 & sugar & 7.5 & 176.63 & 1.97 & 0.00 \\
\hline 10 & 4 & red & 7.3 & 167.33 & 0.21 & 0.38 \\
\hline 10 & 4 & sugar & 5.6 & 98.47 & 10.14 & 0.00 \\
\hline 10 & 5 & red & 9.9 & 307.75 & 0.90 & 12.62 \\
\hline 10 & 5 & sugar & 4.8 & 72.35 & 2.20 & 12.70 \\
\hline 10 & 6 & red & 5.5 & 94.99 & 0.63 & 0.52 \\
\hline 10 & 6 & sugar & 3.9 & 47.76 & 15.56 & 15.86 \\
\hline 10 & 7 & red & 11.4 & 408.07 & 0.61 & 0.33 \\
\hline 10 & 7 & sugar & 4 & 50.24 & 7.56 & 0.55 \\
\hline 10 & 8 & red & 6.8 & 145.19 & 0.75 & 23.28 \\
\hline 10 & 8 & sugar & 5.6 & 98.47 & 10.77 & 5.05 \\
\hline 10 & 9 & red & 5.4 & 91.56 & 29.57 & 24.50 \\
\hline 10 & 9 & sugar & 6.4 & 128.61 & 0.00 & 2.59 \\
\hline 13 & 1 & red & 6.8 & 145.19 & 1.79 & 14.66 \\
\hline 13 & 1 & sugar & 6 & 113.04 & 0.00 & 1.36 \\
\hline 13 & 2 & red & 5.1 & 81.67 & 0.38 & 25.32 \\
\hline 13 & 2 & sugar & 5.9 & 109.30 & 2.14 & 0.00 \\
\hline 13 & 3 & red & 4.5 & 63.59 & 18.24 & 0.45 \\
\hline 13 & 3 & sugar & 4 & 50.24 & 2.44 & 45.32 \\
\hline 13 & 4 & red & 5.1 & 81.67 & 3.34 & 0.26 \\
\hline 13 & 4 & sugar & 7.2 & 162.78 & 8.44 & 35.60 \\
\hline 13 & 5 & red & 5.2 & 84.91 & 54.02 & 39.79 \\
\hline 13 & 5 & sugar & 5.8 & 105.63 & 3.60 & 10.40 \\
\hline 13 & 6 & red & 6.2 & 120.70 & 2.05 & 0.00 \\
\hline 13 & 6 & sugar & 5.8 & 105.63 & 0.80 & 39.96 \\
\hline 13 & 7 & red & 4.6 & 66.44 & 3.58 & 46.00 \\
\hline 13 & 7 & sugar & 6.1 & 116.84 & 14.73 & 0.00 \\
\hline 13 & 8 & red & 6.8 & 145.19 & 1.05 & 37.90 \\
\hline 13 & 8 & sugar & 8.3 & 216.31 & 5.88 & 34.16 \\
\hline 13 & 9 & red & 5.8 & 105.63 & 18.17 & 16.41 \\
\hline 13 & 9 & sugar & 7.4 & 171.95 & 1.52 & 5.78 \\
\hline
\end{tabular}


Table A3. Total cover (in $\mathrm{dm}^{2}$ per $36 \mathrm{~m}^{2}$ ) of all understory taxa in this study in each watershed for each overstory maple species ( $R=$ red maple, $S=$ sugar maple).

\begin{tabular}{|c|c|c|c|c|c|c|c|c|c|}
\hline \multicolumn{10}{|c|}{ Watershed and plot-center maple } \\
\hline \multicolumn{2}{|c|}{ Understory species } & $\begin{array}{c}\text { WS3 } \\
\text { R }\end{array}$ & $\begin{array}{c}\text { WS3 } \\
\text { S }\end{array}$ & $\begin{array}{c}\text { WS7 } \\
\text { R }\end{array}$ & $\begin{array}{c}\text { WS7 } \\
\text { S }\end{array}$ & $\begin{array}{c}\text { WS10 } \\
\text { R }\end{array}$ & $\begin{array}{c}\text { WS10 } \\
\text { S }\end{array}$ & $\begin{array}{c}\text { WS13 } \\
\text { R }\end{array}$ & $\begin{array}{c}\text { WS13 } \\
\text { S }\end{array}$ \\
\hline $\begin{array}{l}\text { Acer } \\
\text { pensylvanicum }\end{array}$ & Striped maple & 36 & 72 & 120.5 & 131.7 & 41.75 & 7.35 & 86.15 & 42 \\
\hline Acer rubrum & Red maple & 11.09 & 45.55 & 13.14 & 32 & 17.6 & 19.3 & 26.8 & 47.92 \\
\hline $\begin{array}{l}\text { Acer } \\
\text { saccharinum }\end{array}$ & Silver maple & 4 & 0 & 0 & 0 & 0 & 0 & 0 & 0 \\
\hline $\begin{array}{l}\text { Acer } \\
\text { saccharum }\end{array}$ & Sugar maple & 0 & 0 & 16.95 & 1.5 & 0.5 & 3.8 & 1.55 & 2.87 \\
\hline $\begin{array}{l}\text { Actaea } \\
\text { racemosa }\end{array}$ & Black cohosh & 0 & 0 & 2 & 0 & 0 & 0 & 0 & 0 \\
\hline Anemone spp. & Wood thimble & 0 & 0 & 0 & 5.15 & 0 & 5.5 & 0 & 0.5 \\
\hline $\begin{array}{l}\text { Arisaema } \\
\text { triphyllum }\end{array}$ & Jack-in-the-pulpit & 0.1 & 0.05 & 2.5 & 3.25 & 1 & 1 & 0 & 0.5 \\
\hline $\begin{array}{l}\text { Aruncus } \\
\text { dioicus }\end{array}$ & Goat's beard & 0 & 0 & 0.75 & 0 & 0 & 0 & 0 & 0 \\
\hline $\begin{array}{l}\text { Aster } \\
\text { divaricatus }\end{array}$ & Heartleaf aster & 0 & 0 & 8.25 & 2.5 & 8.6 & 5.6 & 3.1 & 2.5 \\
\hline $\begin{array}{l}\text { Athyrium filix- } \\
\text { femina }\end{array}$ & Lady fern & 4.75 & 0 & 2.75 & 1.05 & 0 & 0 & 0 & 5 \\
\hline Betula lenta & Sweet birch & 12 & 4.75 & 0.5 & 0 & 3 & 9.75 & 0 & 0 \\
\hline $\begin{array}{l}\text { Carya } \\
\text { cordiformis }\end{array}$ & Bitternut hickory & 0 & 0 & 3 & 0 & 0 & 0 & 0 & 0 \\
\hline $\begin{array}{l}\text { Castanea } \\
\text { dentata }\end{array}$ & American chestnut & 0 & 0 & 0 & 0 & 0 & 6.5 & 0 & 0.25 \\
\hline $\begin{array}{l}\text { Conopholis } \\
\text { americana }\end{array}$ & Squawroot & 0 & 0 & 0 & 0 & 0.5 & 1 & 0 & 0 \\
\hline $\begin{array}{l}\text { Cornus } \\
\text { alternifolia }\end{array}$ & $\begin{array}{l}\text { Alternate leaf } \\
\text { dogwood }\end{array}$ & 0 & 0 & 8 & 4.25 & 0 & 0 & 0 & 0 \\
\hline $\begin{array}{l}\text { Cypripedium } \\
\text { acaule }\end{array}$ & Lady slipper & 0 & 0 & 2 & 0 & 2.25 & 0 & 0.45 & 0 \\
\hline $\begin{array}{l}\text { Dennstaedtia } \\
\text { punctilobula }\end{array}$ & Hay-scented fern & 155.5 & 180.5 & 127 & 86.1 & 0 & 27 & 0 & 0 \\
\hline $\begin{array}{l}\text { Dioscorea } \\
\text { quaternata }\end{array}$ & Wild yam & 1 & 0 & 12 & 7.5 & 4.85 & 4.7 & 2 & 7.85 \\
\hline $\begin{array}{l}\text { Disporum } \\
\text { lanuginosum }\end{array}$ & Fairy bells & 0 & 0.5 & 20.5 & 28.75 & 1.3 & 1.25 & 5.1 & 10.85 \\
\hline $\begin{array}{l}\text { Dryopteris } \\
\text { intermedia }\end{array}$ & $\begin{array}{l}\text { Intermediate wood } \\
\text { fern }\end{array}$ & 170.9 & 169 & 228.25 & 235.3 & 0 & 0 & 49.5 & 0 \\
\hline $\begin{array}{l}\text { Fagus } \\
\text { grandifolia }\end{array}$ & American beech & 0 & 0 & 0 & 0 & 1.3 & 0 & 7 & 0.75 \\
\hline
\end{tabular}


Table A3 continued.

\begin{tabular}{|c|c|c|c|c|c|c|c|c|c|}
\hline \multicolumn{10}{|c|}{ Watershed and plot-center maple } \\
\hline \multicolumn{2}{|c|}{ Understory species } & WS3 & WS3 & WS7 & WS7 & WS10 & WS10 & WS13 & WS13 \\
\hline $\begin{array}{l}\text { Fraxinus } \\
\text { americana }\end{array}$ & White ash & 0 & 14 & 1.95 & 2.25 & 2.5 & 41.5 & 0.9 & 12.75 \\
\hline $\begin{array}{l}\text { Galium } \\
\text { asprellum }\end{array}$ & Bedstraw & 0 & 0 & 0 & 0.2 & 0 & 0 & 0 & 0 \\
\hline $\begin{array}{l}\text { Galium } \\
\text { lanceolatum }\end{array}$ & Wild licorice & 0 & 0 & 0.2 & 0 & 0 & 0.5 & 0 & 0 \\
\hline $\begin{array}{l}\text { Galium } \\
\text { triflorum }\end{array}$ & Three leaf bedstraw & 0 & 0 & 0.25 & 0 & 0 & 0 & 0 & 0 \\
\hline $\begin{array}{l}\text { Goodyera } \\
\text { pubescens }\end{array}$ & $\begin{array}{l}\text { Downy rattlesnake } \\
\text { plantain }\end{array}$ & 0 & 0 & 0 & 1.75 & 0 & 0 & 0 & 0.5 \\
\hline Graminoids & Grasses, sedges & 0 & 0 & 5.7 & 9.1 & 0.5 & 0.2 & 0.2 & 1.5 \\
\hline $\begin{array}{l}\text { Hamamelis } \\
\text { virginiana }\end{array}$ & Witch hazel & 0 & 2.25 & 0 & 0 & 2.25 & 4.75 & 0 & 0 \\
\hline Ilex Montana & Big leaf holly & 1.15 & 1.25 & 0 & 0 & 0 & 0 & 0 & 0 \\
\hline Kalmia latifolia & Mountain laurel & 0 & 0 & 0 & 0 & 1.15 & 0 & 0 & 0 \\
\hline $\begin{array}{l}\text { Laportea } \\
\text { canadensis }\end{array}$ & Nettle & 0 & 3 & 34.5 & 60.25 & 0 & 3 & 0 & 0 \\
\hline $\begin{array}{l}\text { Lindera } \\
\text { benzoin }\end{array}$ & Spicebush & 1.3 & 0 & 0 & 0 & 2.5 & 0 & 0 & 0 \\
\hline $\begin{array}{l}\text { Liridendron } \\
\text { tulipifera }\end{array}$ & Tulip poplar & 0 & 0 & 0 & 1.5 & 14.2 & 14.15 & 1.3 & 6.95 \\
\hline $\begin{array}{l}\text { Magnolia } \\
\text { acuminata }\end{array}$ & Cucumber tree & 13.5 & 13.25 & 0 & 2.5 & 27.4 & 53 & 5.15 & 15.25 \\
\hline $\begin{array}{l}\text { Magnolia } \\
\text { fraseri }\end{array}$ & Umbrella tree & 0 & 0 & 0 & 0 & 0 & 4 & 0 & 1.25 \\
\hline $\begin{array}{l}\text { Maianthemum } \\
\text { racemosum }\end{array}$ & False solomon's seal & 0 & 0 & 0 & 0 & 0 & 0 & 3 & 0 \\
\hline $\begin{array}{l}\text { Medeola } \\
\text { virginiana }\end{array}$ & Indian cucumber root & 8.45 & 2.5 & 15.75 & 4.6 & 2.85 & 0.1 & 1 & 1.9 \\
\hline $\begin{array}{l}\text { Menziesia } \\
\text { pilosa }\end{array}$ & Minniebush & 0 & 0 & 0 & 0 & 1 & 2.75 & 0 & 0 \\
\hline $\begin{array}{l}\text { Mitchella } \\
\text { repens }\end{array}$ & Partridge berry & 0.15 & 0 & 0 & 0 & 1 & 0.75 & 0 & 0 \\
\hline $\begin{array}{l}\text { Monotropa } \\
\text { uniflora }\end{array}$ & Indian pipe & 0 & 0 & 0 & 0 & 0 & 0.2 & 0 & 0 \\
\hline Nyssa sylvatica & Blackgum & 0 & 0 & 0 & 1.5 & 0 & 0 & 0 & 0 \\
\hline $\begin{array}{l}\text { Osmorhiza } \\
\text { claytonii }\end{array}$ & Sweet cicely & 0 & 0 & 3 & 1.7 & 0 & 0 & 0 & 0 \\
\hline $\begin{array}{l}\text { Ostrya } \\
\text { virginiana }\end{array}$ & Ironwood & 1.37 & 0 & 0.5 & 7 & 7 & 4 & 4.5 & 16.75 \\
\hline
\end{tabular}


Table A3 continued.

\begin{tabular}{|c|c|c|c|c|c|c|c|c|c|}
\hline \multicolumn{10}{|c|}{ Watershed and plot-center maple } \\
\hline \multicolumn{2}{|c|}{ Understory species } & WS3 & WS3 & WS7 & WS7 & WS10 & WS10 & WS13 & WS13 \\
\hline $\begin{array}{l}\text { Parthenocissus } \\
\text { quinquefolia }\end{array}$ & Virginia creeper & 0 & 0 & 1.5 & 0 & 0 & 0 & 0 & 0 \\
\hline $\begin{array}{l}\text { Polygonatum } \\
\text { biflorum }\end{array}$ & Solomon's seal & 0 & 0 & 10.25 & 4.75 & 0 & 0 & 0 & 2.6 \\
\hline $\begin{array}{l}\text { Polygonum } \\
\text { cuspidatum }\end{array}$ & Japanese knotweed & 5.5 & 1 & 12 & 2.5 & 0 & 0 & 0 & 1 \\
\hline $\begin{array}{l}\text { Polystichum } \\
\text { acrostichoides }\end{array}$ & Christmas fern & 24.25 & 70.5 & 99.65 & 121.5 & 15.75 & 79.25 & 46 & 74.75 \\
\hline Prunus serotina & Black cherry & 3.8 & 6.5 & 3.4 & 7.1 & 1.05 & 4.15 & 4.15 & 6.9 \\
\hline Quercus alba & White oak & 0 & 0 & 0 & 1 & 3.25 & 0 & 0.25 & 0 \\
\hline Quercus prinus & Chestnut oak & 0 & 0 & 0 & 0 & 2.4 & 1.5 & 0 & 2.75 \\
\hline Quercus rubra & Red oak & 7.5 & 9.25 & 1.75 & 4.5 & 33.95 & 36.75 & 75.15 & 87.9 \\
\hline $\begin{array}{l}\text { Rhododendron } \\
\text { calendulaceum }\end{array}$ & Azalea & 0 & 0 & 0 & 0 & 18.25 & 3.15 & 0 & 0 \\
\hline Rosa multiflora & Multiflora rose & 0 & 0 & 0 & 29.75 & 0 & 0 & 0 & 0 \\
\hline Rubus Spp. & Blackberry & 436.6 & 504.25 & 198.4 & 212.5 & 29.9 & 163.75 & 106.75 & 276.25 \\
\hline $\begin{array}{l}\text { Sambucus } \\
\text { nigra }\end{array}$ & Elderberry & 0 & 0 & 5 & 0 & 0 & 0 & 0 & 0 \\
\hline $\begin{array}{l}\text { Sassafras } \\
\text { albidum }\end{array}$ & Sassafras & 0 & 0 & 12.5 & 6.25 & 0 & 0.75 & 0 & 0 \\
\hline $\begin{array}{l}\text { Smilax } \\
\text { herbacea }\end{array}$ & Smooth carrionflower & 1.75 & 0 & 1.5 & 0.5 & 0 & 0 & 0 & 0 \\
\hline $\begin{array}{l}\text { Smilax } \\
\text { rotundifolia }\end{array}$ & Greenbrier & 103.7 & 111.25 & 33.65 & 122.5 & 150.8 & 63.5 & 31 & 27.55 \\
\hline Stellaria pubera & Star chickweed & 0.75 & 16.9 & 83.25 & 53.1 & 4.4 & 3.25 & 6.25 & 11.85 \\
\hline $\begin{array}{l}\text { Thelypteris } \\
\text { noveboracensis }\end{array}$ & New York fern & 52.5 & 41 & 80.5 & 39.5 & 35.75 & 62 & 85.5 & 68 \\
\hline Trillium & Trillium & 0 & 0 & 5.35 & 0 & 0 & 0 & 0 & 0 \\
\hline $\begin{array}{l}\text { Vaccinium } \\
\text { pallidum }\end{array}$ & Blueberry & 0 & 0 & 0 & 0 & 8.75 & 12.5 & 0 & 1.25 \\
\hline $\begin{array}{l}\text { Vibernum } \\
\text { acerifolium }\end{array}$ & Maple leaf viburnum & 0 & 0.25 & 0.25 & 0 & 5.85 & 1.8 & 0 & 2.75 \\
\hline Viola Spp. & Violets & 11.7 & 9.05 & 122.25 & 80.75 & 44.55 & 54.35 & 48.55 & 61.5 \\
\hline Unknown & Unknown species & 0 & 0 & 0 & 2.25 & 0 & 0.67 & 0.5 & 0 \\
\hline
\end{tabular}


Table A4. ANOVA results testing the effect of watershed (WS), overstory maple species (M) and their interaction (WS $\times$ M) for 22 individual herb-layer species in the three watershed pairs. The Benjamini Hochberg method was applied to account for the familywise error rate. ANOVA Pvalues smaller than the Benjamini-Hochberg critical value (BH FDR.1) (in bold font) indicate that the discoveries are not a false-positives (based on an assumed false discovery rate (FDR) of $0.1)$.

\begin{tabular}{|c|c|c|c|c|c|c|c|}
\hline \multicolumn{8}{|l|}{ WS3 vs WS7 } \\
\hline Species & Effect & NumDF & DenDF & FValue & ProbF & Rank & BH FDR.1 \\
\hline Violets & WS & 1 & 24 & 32.48 & $0.0001^{*}$ & 1 & 0.001818 \\
\hline New York fern & WS $\times M$ & 1 & 5 & 33.74 & $0.0021^{*}$ & 2 & 0.003636 \\
\hline Jack-in-the-pulpit & WS & 1 & 5 & 25.85 & $0.0038^{*}$ & 3 & 0.005455 \\
\hline Sweet/Black Birch & WS & 1 & 4 & 16.62 & 0.0151 & 4 & 0.007273 \\
\hline Fairy Bells & WS & 1 & 11 & 7.62 & 0.0185 & 5 & 0.009091 \\
\hline Fairy Bells & $\mathrm{M}$ & 1 & 11 & 7.26 & 0.0209 & 6 & 0.010909 \\
\hline Red Maple & $\mathrm{M}$ & 1 & 25 & 5.63 & 0.0257 & 7 & 0.012727 \\
\hline Star chickweed & WS & 1 & 18 & 5.55 & 0.03 & 8 & 0.014545 \\
\hline Sweet/Black Birch & $\bar{M}$ & 1 & 4 & 6.45 & 0.064 & 9 & 0.016364 \\
\hline New York fern & WS & 1 & 5 & 5.61 & 0.0641 & 10 & 0.018182 \\
\hline Blackberry & WS & 1 & 29 & 3.6 & 0.0676 & 11 & 0.02 \\
\hline Violets & $\mathrm{WS} \times \mathrm{M}$ & 1 & 24 & 3.42 & 0.0769 & 12 & 0.021818 \\
\hline White Ash & WS & 1 & 3 & 5.76 & 0.0959 & 13 & 0.023636 \\
\hline Jack-in-the-pulpit & $\mathrm{M}$ & 1 & 5 & 3.05 & 0.1411 & 14 & 0.025455 \\
\hline Hay-scented fern & $\mathrm{M}$ & 1 & 19 & 2.28 & 0.1477 & 15 & 0.027273 \\
\hline Cucumber tree & WS & 1 & 1 & 13.03 & 0.1721 & 16 & 0.029091 \\
\hline Indian Cucumber & $\mathrm{WS} \times \mathrm{M}$ & 1 & 8 & 1.79 & 0.2172 & 17 & 0.030909 \\
\hline Japanese knotweed & $\mathrm{M}$ & 1 & 2 & 3.09 & 0.2211 & 18 & 0.032727 \\
\hline Japanese knotweed & WS & 1 & 2 & 2.69 & 0.2424 & 19 & 0.034545 \\
\hline Intermediate wood fern & $\mathrm{M}$ & 1 & 19 & 1.38 & 0.2554 & 20 & 0.036364 \\
\hline hay-scented fern & WS & 1 & 19 & 1.37 & 0.2559 & 21 & 0.038182 \\
\hline Roundleaf greenbrier & $\mathrm{WS} \times \mathrm{M}$ & 1 & 23 & 1.24 & 0.2762 & 22 & 0.04 \\
\hline New York fern & $\mathrm{M}$ & 1 & 5 & 1.44 & 0.2843 & 23 & 0.041818 \\
\hline Indian Cucumber & $\bar{M}$ & 1 & 8 & 1.29 & 0.2882 & 24 & 0.043636 \\
\hline Red Oak & WS $\times M$ & 1 & 4 & 1.15 & 0.3434 & 25 & 0.045455 \\
\hline Intermediate wood fern & WS & 1 & 19 & 0.93 & 0.3476 & 26 & 0.047273 \\
\hline
\end{tabular}


Table A4 continued.

\begin{tabular}{|c|c|c|c|c|c|c|c|}
\hline WS3 vs WS7 & & & & & & & \\
\hline Species & Effect & NumDF & DenDF & FValue & ProbF & Rank & BH FDR.1 \\
\hline Striped Maple & WS & 1 & 21 & 0.92 & 0.3486 & 27 & 0.049091 \\
\hline Violets & $\mathrm{M}$ & 1 & 24 & 0.8 & 0.3802 & 28 & 0.050909 \\
\hline Black Cherry & M & 1 & 23 & 0.76 & 0.3916 & 29 & 0.052727 \\
\hline Black Cherry & WS & 1 & 23 & 0.7 & 0.4118 & 30 & 0.054545 \\
\hline Red Oak & WS & 1 & 4 & 0.69 & 0.4537 & 31 & 0.056364 \\
\hline Red Maple & WS & 1 & 25 & 0.55 & 0.4635 & 32 & 0.058182 \\
\hline Cucumber tree & WS $\times M$ & 1 & 1 & 1.18 & 0.4742 & 33 & 0.06 \\
\hline Christmas fern & M & 1 & 12 & 0.53 & 0.4819 & 34 & 0.061818 \\
\hline Red Maple & WS $\times M$ & 1 & 25 & 0.46 & 0.5044 & 35 & 0.063636 \\
\hline Wild Yam & WS & 1 & 6 & 0.48 & 0.5162 & 36 & 0.065455 \\
\hline Sugar Maple & M & 1 & 5 & 0.4 & 0.5526 & 37 & 0.067273 \\
\hline Indian Cucumber & WS & 1 & 8 & 0.38 & 0.5546 & 38 & 0.069091 \\
\hline roundleaf greenbrier & M & 1 & 23 & 0.26 & 0.6123 & 39 & 0.070909 \\
\hline Red Oak & $\mathrm{M}$ & 1 & 4 & 0.22 & 0.6623 & 40 & 0.072727 \\
\hline Star chickweed & M & 1 & 18 & 0.15 & 0.706 & 41 & 0.074545 \\
\hline Black Cherry & WS $\times M$ & 1 & 23 & 0.13 & 0.7218 & 42 & 0.076364 \\
\hline Roundleaf greenbrier & WS & 1 & 23 & 0.1 & 0.7535 & 43 & 0.078182 \\
\hline Cucumber tree & M & 1 & 1 & 0.12 & 0.7838 & 44 & 0.08 \\
\hline Striped Maple & M & 1 & 21 & 0.07 & 0.7945 & 45 & 0.081818 \\
\hline Intermediate wood fern & WS $\times M$ & 1 & 19 & 0.06 & 0.8025 & 46 & 0.083636 \\
\hline Japanese knotweed & WS $\times M$ & 1 & 2 & 0.05 & 0.8472 & 47 & 0.085455 \\
\hline Christmas fern & WS $\times M$ & 1 & 12 & 0.04 & 0.8498 & 48 & 0.087273 \\
\hline White Ash & M & 1 & 3 & 0.03 & 0.8703 & 49 & 0.089091 \\
\hline Blackberry & $\bar{M}$ & 1 & 29 & 0.02 & 0.8834 & 50 & 0.090909 \\
\hline Wild Yam & $\bar{M}$ & 1 & 6 & 0.01 & 0.9153 & 51 & 0.092727 \\
\hline Blackberry & WS $\times M$ & 1 & 29 & 0.01 & 0.9359 & 52 & 0.094545 \\
\hline Hay-scented fern & WS $\times M$ & 1 & 19 & 0 & 0.9506 & 53 & 0.096364 \\
\hline Christmas fern & WS & 1 & 12 & 0 & 0.9676 & 54 & 0.098182 \\
\hline Striped Maple & WS $\times M$ & 1 & 21 & 0 & 0.9935 & 55 & 0.1 \\
\hline
\end{tabular}


Table A4 continued.

\begin{tabular}{|c|c|c|c|c|c|c|c|}
\hline \multicolumn{8}{|l|}{ WS7 vs WS13 } \\
\hline Species & Effect & NumDF & DenDF & FValue & ProbF & rank & BH FDR. 1 \\
\hline Red Maple & $\mathrm{M}$ & 1 & 27 & 16.73 & $0.0003^{*}$ & 1 & 0.001724 \\
\hline Fairy Bells & WS & 1 & 20 & 8.7 & 0.0079 & 2 & 0.003448 \\
\hline Star chickweed & WS & 1 & 19 & 8.52 & 0.0088 & 3 & 0.005172 \\
\hline New York fern & $W S \times M$ & 1 & 6 & 13.29 & 0.0108 & 4 & 0.006897 \\
\hline Fairy Bells & $\mathrm{M}$ & 1 & 20 & 6.94 & 0.0159 & 5 & 0.008621 \\
\hline Jack-in-the-pulpit & WS & 1 & 5 & 8.27 & 0.0347 & 6 & 0.010345 \\
\hline Red Oak & WS & 1 & 10 & 5.77 & 0.0372 & 7 & 0.012069 \\
\hline Violets & wS & 1 & 29 & 2.85 & 0.1023 & 8 & 0.013793 \\
\hline Blackberry & $W S \times M$ & 1 & 20 & 2.53 & 0.1271 & 9 & 0.015517 \\
\hline New York fern & WS & 1 & 6 & 3.04 & 0.1319 & 10 & 0.017241 \\
\hline Blackberry & $\mathrm{M}$ & 1 & 20 & 2.36 & 0.1405 & 11 & 0.018966 \\
\hline Hay-scented fern & $\mathrm{M}$ & 1 & 11 & 2.44 & 0.1469 & 12 & 0.02069 \\
\hline Jack-in-the-pulpit & $\bar{M}$ & 1 & 5 & 2.87 & 0.1512 & 13 & 0.022414 \\
\hline Blackberry & WS & 1 & 20 & 1.73 & 0.2029 & 14 & 0.024138 \\
\hline Cucumber tree & WS & 1 & 3 & 2.54 & 0.2091 & 15 & 0.025862 \\
\hline Tulip/Yellow Poplar & $\mathrm{M}$ & 1 & 2 & 3.25 & 0.213 & 16 & 0.027586 \\
\hline Indian Cucumber & $W S \times M$ & 1 & 5 & 1.92 & 0.2242 & 17 & 0.02931 \\
\hline Indian Cucumber & WS & 1 & 5 & 1.78 & 0.2392 & 18 & 0.031034 \\
\hline Violets & $W S \times M$ & 1 & 29 & 1.26 & 0.2707 & 19 & 0.032759 \\
\hline Wild Yam & WS & 1 & 10 & 1.26 & 0.2885 & 20 & 0.034483 \\
\hline Roundleaf greenbrier & WS & 1 & 17 & 0.97 & 0.3375 & 21 & 0.036207 \\
\hline Sugar Maple & WS $\times M$ & 1 & 9 & 0.93 & 0.3598 & 22 & 0.037931 \\
\hline Striped Maple & WS & 1 & 24 & 0.83 & 0.3717 & 23 & 0.039655 \\
\hline Sugar Maple & WS & 1 & 9 & 0.84 & 0.3827 & 24 & 0.041379 \\
\hline Tulip/Yellow Poplar & WS & 1 & 2 & 1.04 & 0.4157 & 25 & 0.043103 \\
\hline White Ash & $\mathrm{M}$ & 1 & 7 & 0.55 & 0.4818 & 26 & 0.044828 \\
\hline Roundleaf greenbrier & WS $\times M$ & 1 & 17 & 0.51 & 0.4842 & 27 & 0.046552 \\
\hline Japanese knotweed & WS & 1 & 1 & 0.86 & 0.5247 & 28 & 0.048276 \\
\hline Intermediate wood fern & $W S \times M$ & 1 & 9 & 0.43 & 0.5304 & 29 & 0.05 \\
\hline Christmas fern & WS & 1 & 14 & 0.4 & 0.5372 & 30 & 0.051724 \\
\hline Japanese knotweed & $\mathrm{M}$ & 1 & 1 & 0.78 & 0.5394 & 31 & 0.053448 \\
\hline Roundleaf greenbrier & $\mathrm{M}$ & 1 & 17 & 0.39 & 0.5429 & 32 & 0.055172 \\
\hline Christmas fern & $\mathrm{M}$ & 1 & 14 & 0.39 & 0.5444 & 33 & 0.056897 \\
\hline Indian Cucumber & $\mathrm{M}$ & 1 & 5 & 0.37 & 0.5718 & 34 & 0.058621 \\
\hline Striped Maple & $W S \times M$ & 1 & 24 & 0.31 & 0.5822 & 35 & 0.060345 \\
\hline New York fern & 14 & 1 & 6 & 0.33 & 0.5851 & 36 & 0.062069 \\
\hline Cucumber tree & M & 1 & 3 & 0.32 & 0.6094 & 37 & 0.063793 \\
\hline
\end{tabular}


Table A4 continued.

\begin{tabular}{|c|c|c|c|c|c|c|c|}
\hline \multicolumn{8}{|l|}{ WS7 vs WS13 } \\
\hline Species & Effect & NumDF & DenDF & FValue & ProbF & rank & BH FDR.1 \\
\hline White Ash & $W S \times M$ & 1 & 7 & 0.28 & 0.6137 & 38 & 0.065517 \\
\hline Red Oak & $W S \times M$ & 1 & 10 & 0.27 & 0.6177 & 39 & 0.067241 \\
\hline Black Cherry & $W S \times M$ & 1 & 16 & 0.21 & 0.651 & 40 & 0.068966 \\
\hline Fairy Bells & $W S \times M$ & 1 & 20 & 0.2 & 0.657 & 41 & 0.07069 \\
\hline Star chickweed & $W S \times M$ & 1 & 19 & 0.17 & 0.6843 & 42 & 0.072414 \\
\hline Intermediate wood fern & WS & 1 & 9 & 0.1 & 0.7543 & 43 & 0.074138 \\
\hline Striped Maple & M & 1 & 24 & 0.07 & 0.8008 & 44 & 0.075862 \\
\hline Wild Yam & $M$ & 1 & 10 & 0.06 & 0.817 & 45 & 0.077586 \\
\hline Red Maple & $W S \times M$ & 1 & 27 & 0.05 & 0.8278 & 46 & 0.07931 \\
\hline Intermediate wood fern & M & 1 & 9 & 0.04 & 0.8504 & 47 & 0.081034 \\
\hline Black Cherry & WS & 1 & 16 & 0.04 & 0.8516 & 48 & 0.082759 \\
\hline White Ash & WS & 1 & 7 & 0.03 & 0.8768 & 49 & 0.084483 \\
\hline Red Oak & $\mathrm{M}$ & 1 & 10 & 0.02 & 0.8943 & 50 & 0.086207 \\
\hline Wild Yam & $W S \times M$ & 1 & 10 & 0.01 & 0.9136 & 51 & 0.087931 \\
\hline Black Cherry & $\mathrm{M}$ & 1 & 16 & 0.01 & 0.9179 & 52 & 0.089655 \\
\hline Violets & $M$ & 1 & 29 & 0.01 & 0.927 & 53 & 0.091379 \\
\hline Christmas fern & $W S \times M$ & 1 & 14 & 0 & 0.9452 & 54 & 0.093103 \\
\hline Cucumber tree & $W S \times M$ & 1 & 3 & 0 & 0.9512 & 55 & 0.094828 \\
\hline Sugar Maple & $M$ & 1 & 9 & 0 & 0.981 & 56 & 0.096552 \\
\hline Red Maple & WS & 1 & 27 & 0 & 0.9841 & 57 & 0.098276 \\
\hline Star chickweed & $\mathrm{M}$ & 1 & 19 & 0 & 0.9979 & 58 & 0.1 \\
\hline \multicolumn{8}{|l|}{ WS 10 vs WS13 } \\
\hline Red Maple & $\mathrm{M}$ & 1 & 30 & 16.28 & $0.0003^{*}$ & 1 & 0.001852 \\
\hline Red Oak & WS & 1 & 20 & 5.57 & 0.0285 & 2 & 0.003704 \\
\hline Tulip/Yellow Poplar & $W S \times M$ & 1 & 8 & 4.45 & 0.0678 & 3 & 0.005556 \\
\hline New York fern & $W S \times M$ & 1 & 6 & 3.26 & 0.1211 & 4 & 0.007407 \\
\hline Red Maple & WS & 1 & 30 & 2.44 & 0.1284 & 5 & 0.009259 \\
\hline New York fern & $\mathrm{M}$ & 1 & 6 & 2.87 & 0.1412 & 6 & 0.011111 \\
\hline Striped Maple & $\mathrm{M}$ & 1 & 18 & 2.33 & 0.1444 & 7 & 0.012963 \\
\hline Roundleaf greenbrier & $\mathrm{M}$ & 1 & 19 & 2.23 & 0.1518 & 8 & 0.014815 \\
\hline White Ash & $\mathrm{M}$ & 1 & 8 & 2.5 & 0.1522 & 9 & 0.016667 \\
\hline Sugar Maple & $W S \times M$ & 1 & 8 & 2.44 & 0.1569 & 10 & 0.018519 \\
\hline Striped Maple & WS & 1 & 18 & 1.97 & 0.1779 & 11 & 0.02037 \\
\hline Roundleaf greenbrier & $W S \times M$ & 1 & 19 & 1.93 & 0.1812 & 12 & 0.022222 \\
\hline Indian Cucumber & $W S \times M$ & 1 & 3 & 2.43 & 0.2166 & 13 & 0.024074 \\
\hline Jack-in-the-pulpit & WS & 1 & 2 & 3.01 & 0.225 & 14 & 0.025926 \\
\hline Fairy Bells & WS & 1 & 11 & 1.54 & 0.2401 & 15 & 0.027778 \\
\hline
\end{tabular}


Table A4 continued.

\begin{tabular}{|c|c|c|c|c|c|c|c|}
\hline \multicolumn{8}{|l|}{ WS10 vs WS13 } \\
\hline Species & Effect & NumDF & DenDF & FValue & ProbF & rank & BH FDR. 1 \\
\hline Cucumber tree & $W S \times M$ & 1 & 9 & 1.41 & 0.2647 & 16 & 0.02963 \\
\hline Sugar Maple & WS & 1 & 8 & 1.41 & 0.2695 & 17 & 0.031481 \\
\hline Blackberry & $W S \times M$ & 1 & 11 & 1.16 & 0.3042 & 18 & 0.033333 \\
\hline Blackberry & WS & 1 & 11 & 1.1 & 0.317 & 19 & 0.035185 \\
\hline Red Maple & $W S \times M$ & 1 & 30 & 1.01 & 0.3229 & 20 & 0.037037 \\
\hline Christmas fern & $M$ & 1 & 10 & 0.97 & 0.3477 & 21 & 0.038889 \\
\hline Fairy Bells & $W S \times M$ & 1 & 11 & 0.94 & 0.3535 & 22 & 0.040741 \\
\hline Blackberry & $\mathrm{M}$ & 1 & 11 & 0.9 & 0.362 & 23 & 0.042593 \\
\hline Indian Cucumber & $\mathrm{M}$ & 1 & 3 & 0.85 & 0.4255 & 24 & 0.044444 \\
\hline Jack-in-the-pulpit & $\mathrm{M}$ & 1 & 2 & 0.97 & 0.4284 & 25 & 0.046296 \\
\hline Sweet/Black Birch & M & 1 & 1 & 1.47 & 0.4392 & 26 & 0.048148 \\
\hline Red Oak & $\mathrm{M}$ & 1 & 20 & 0.61 & 0.4434 & 27 & 0.05 \\
\hline Violets & WS & 1 & 24 & 0.58 & 0.4532 & 28 & 0.051852 \\
\hline Striped Maple & $W S \times M$ & 1 & 18 & 0.56 & 0.4646 & 29 & 0.053704 \\
\hline Roundleaf greenbrier & WS & 1 & 19 & 0.55 & 0.4685 & 30 & 0.055556 \\
\hline White Ash & WS & 1 & 8 & 0.58 & 0.4687 & 31 & 0.057407 \\
\hline Cucumber tree & M & 1 & 9 & 0.55 & 0.4776 & 32 & 0.059259 \\
\hline Tulip/Yellow Poplar & $\mathrm{M}$ & 1 & 8 & 0.52 & 0.492 & 33 & 0.061111 \\
\hline Black Cherry & $W S \times M$ & 1 & 10 & 0.42 & 0.5307 & 34 & 0.062963 \\
\hline Violets & $W S \times M$ & 1 & 24 & 0.39 & 0.5401 & 35 & 0.064815 \\
\hline White Ash & $W S \times M$ & 1 & 8 & 0.3 & 0.5965 & 36 & 0.066667 \\
\hline Star chickweed & $\mathrm{M}$ & 1 & 9 & 0.29 & 0.6058 & 37 & 0.068519 \\
\hline Black Cherry & WS & 1 & 10 & 0.15 & 0.7081 & 38 & 0.07037 \\
\hline Christmas fern & $W S \times M$ & 1 & 10 & 0.15 & 0.709 & 39 & 0.072222 \\
\hline Violets & $\mathrm{M}$ & 1 & 24 & 0.1 & 0.7515 & 40 & 0.074074 \\
\hline Sugar Maple & M & 1 & 8 & 0.11 & 0.7528 & 41 & 0.075926 \\
\hline Christmas fern & WS & 1 & 10 & 0.1 & 0.7574 & 42 & 0.077778 \\
\hline Black Cherry & $\mathrm{M}$ & 1 & 10 & 0.07 & 0.7967 & 43 & 0.07963 \\
\hline Fairy Bells & $\mathrm{M}$ & 1 & 11 & 0.06 & 0.8099 & 44 & 0.081481 \\
\hline New York fern & WS & 1 & 6 & 0.06 & 0.8211 & 45 & 0.083333 \\
\hline Tulip/Yellow Poplar & WS & 1 & 8 & 0.05 & 0.8371 & 46 & 0.085185 \\
\hline Wild Yam & WS & 1 & 8 & 0.04 & 0.8472 & 47 & 0.087037 \\
\hline Wild Yam & $W S \times M$ & 1 & 8 & 0.04 & 0.8488 & 48 & 0.088889 \\
\hline Star chickweed & $W S \times M$ & 1 & 9 & 0.03 & 0.8579 & 49 & 0.090741 \\
\hline Red Oak & $W S \times M$ & 1 & 20 & 0.02 & 0.8782 & 50 & 0.092593 \\
\hline Wild Yam & $\mathrm{M}$ & 1 & 8 & 0.01 & 0.9164 & 51 & 0.094444 \\
\hline Star chickweed & WS & 1 & 9 & 0.01 & 0.9352 & 52 & 0.096296 \\
\hline Indian Cucumber & WS & 1 & 3 & 0 & 0.98 & 53 & 0.098148 \\
\hline Cucumber tree & WS & 1 & 9 & 0 & 0.9936 & 54 & 0.1 \\
\hline
\end{tabular}


Table A5. Distances between plot center maples (red and sugar maple) within a plot pair (site) and distance between a member of a plot pair to the closest member of a neighboring plot pair. Site 1 is closest to the weir to the left of the stream when facing upstream; numbering proceeds clockwise with Site 9 being closest to the weir on the right side of the stream when facing upstream (See Figure A1).

\begin{tabular}{|c|c|c|c|}
\hline Watershed & Site & Within Site Distance (m) & $\begin{array}{l}\text { Between Site distance } \\
(\mathrm{m})\end{array}$ \\
\hline 3 & 1 & 47.5 & 94 \\
\hline 3 & 2 & 18.7 & 94 \\
\hline 3 & 3 & 30.7 & 154.4 \\
\hline 3 & 4 & 22.9 & 69 \\
\hline 3 & 5 & 30.9 & 69 \\
\hline 3 & 6 & 34 & 169.8 \\
\hline 3 & 7 & 17.8 & 89 \\
\hline 3 & 8 & 40.4 & 89 \\
\hline 3 & 9 & 56 & 98.9 \\
\hline \multicolumn{2}{|c|}{ Average } & & 103.01 \\
\hline 7 & 1 & 19.3 & 141.8 \\
\hline 7 & 2 & 20.8 & 56.7 \\
\hline 7 & 3 & 15.7 & 56.7 \\
\hline 7 & 4 & 29.3 & 109.3 \\
\hline 7 & 5 & 6.2 & 174.8 \\
\hline 7 & 6 & 68.1 & 37.3 \\
\hline 7 & 7 & 24.9 & 37.3 \\
\hline 7 & 8 & 50.8 & 46.7 \\
\hline 7 & 9 & 76.3 & 46.7 \\
\hline \multicolumn{2}{|c|}{ Average } & 34.6 & 78.6 \\
\hline 13 & 1 & 36.85 & 17.9 \\
\hline 13 & 2 & 10.9 & 17.9 \\
\hline 13 & 3 & 45.7 & 43 \\
\hline 13 & 4 & 16 & 119.1 \\
\hline 13 & 5 & 14 & 131 \\
\hline 13 & 6 & 19.4 & 61.2 \\
\hline 13 & 7 & 37.4 & 61.2 \\
\hline 13 & 8 & 19.7 & 60.6 \\
\hline 13 & 9 & 15.6 & 61 \\
\hline \multicolumn{2}{|c|}{ Average } & 23.95 & 63.7 \\
\hline 10 & 1 & 39.2 & 28.6 \\
\hline 10 & 2 & 14.4 & 28.6 \\
\hline 10 & 3 & 63.8 & 63 \\
\hline 10 & 4 & 60.2 & 58.5 \\
\hline 10 & 5 & 83.1 & 58.5 \\
\hline 10 & 6 & 26.2 & 74.1 \\
\hline 10 & 7 & 6.6 & 74.1 \\
\hline 10 & 8 & 13.2 & 65.8 \\
\hline 10 & 9 & 37.5 & 53.7 \\
\hline \multicolumn{2}{|c|}{ Average } & 38.2 & 56.1 \\
\hline
\end{tabular}


Table A6. P-values for individual pairwise comparisons of herb characteristics beneath a given overstory maple species between two watersheds and the comparison of herb characteristics beneath the two overstory maple species within a watershed (SAS AVOVA Effect Slices of the watershed (WS) and overstory maple species (M) interaction).

\begin{tabular}{|c|c|c|c|c|c|c|}
\hline \multicolumn{7}{|c|}{ WS3 vs WS7 } \\
\hline Effect & $\begin{array}{l}\text { Overstory } \\
\text { Maple } \\
\text { Species }\end{array}$ & $\begin{array}{l}\text { Watershed } \\
\text { (WS) }\end{array}$ & $\begin{array}{c}\text { Total Cover } \\
(\%)\end{array}$ & $\begin{array}{c}\text { Species } \\
\text { Richness } \\
\text { (S) }\end{array}$ & $\begin{array}{c}\text { Diversity } \\
(\mathrm{H})\end{array}$ & $\begin{array}{c}\text { Evenness } \\
\text { (J) }\end{array}$ \\
\hline WS $\times \mathbf{M}$ & Red maple & & 0.01 & $<.0001$ & $<.0001$ & 0.08 \\
\hline WS $\times M$ & $\begin{array}{l}\text { Sugar } \\
\text { maple }\end{array}$ & & 0.91 & 0.0073 & 0.01 & 0.13 \\
\hline WS $\times \mathbf{M}$ & & 3 & 0.32 & 0.03 & 0.04 & 0.49 \\
\hline WS $\times \mathbf{M}$ & & 7 & 0.11 & 0.04 & 0.72 & 0.67 \\
\hline \multicolumn{7}{|c|}{ WS7 vs WS13 } \\
\hline WS $\times$ M & Red maple & & 0.0001 & 0.008 & 0.03 & 0.53 \\
\hline$W S \times M$ & $\begin{array}{l}\text { Sugar } \\
\text { maple }\end{array}$ & & 0.17 & 0.83 & 0.06 & 0.01 \\
\hline WS $\times \mathbf{M}$ & & 13 & 0.03 & 0.05 & 0.86 & 0.13 \\
\hline WS $\times M$ & & 7 & 0.27 & 0.39 & 0.95 & 0.51 \\
\hline \multicolumn{7}{|c|}{ WS13 vs WS10 } \\
\hline WS $\times M$ & Red maple & & 0.77 & 0.11 & 0.59 & 0.69 \\
\hline $\mathbf{W S} \times \mathbf{M}$ & $\begin{array}{l}\text { Sugar } \\
\text { maple }\end{array}$ & & 0.05 & 0.68 & 0.18 & 0.02 \\
\hline $\mathbf{W S} \times \mathbf{M}$ & & 10 & 0.64 & 0.96 & 0.27 & 0.04 \\
\hline WS $\times \mathbf{M}$ & & 13 & 0.02 & 0.04 & 0.76 & 0.23 \\
\hline
\end{tabular}




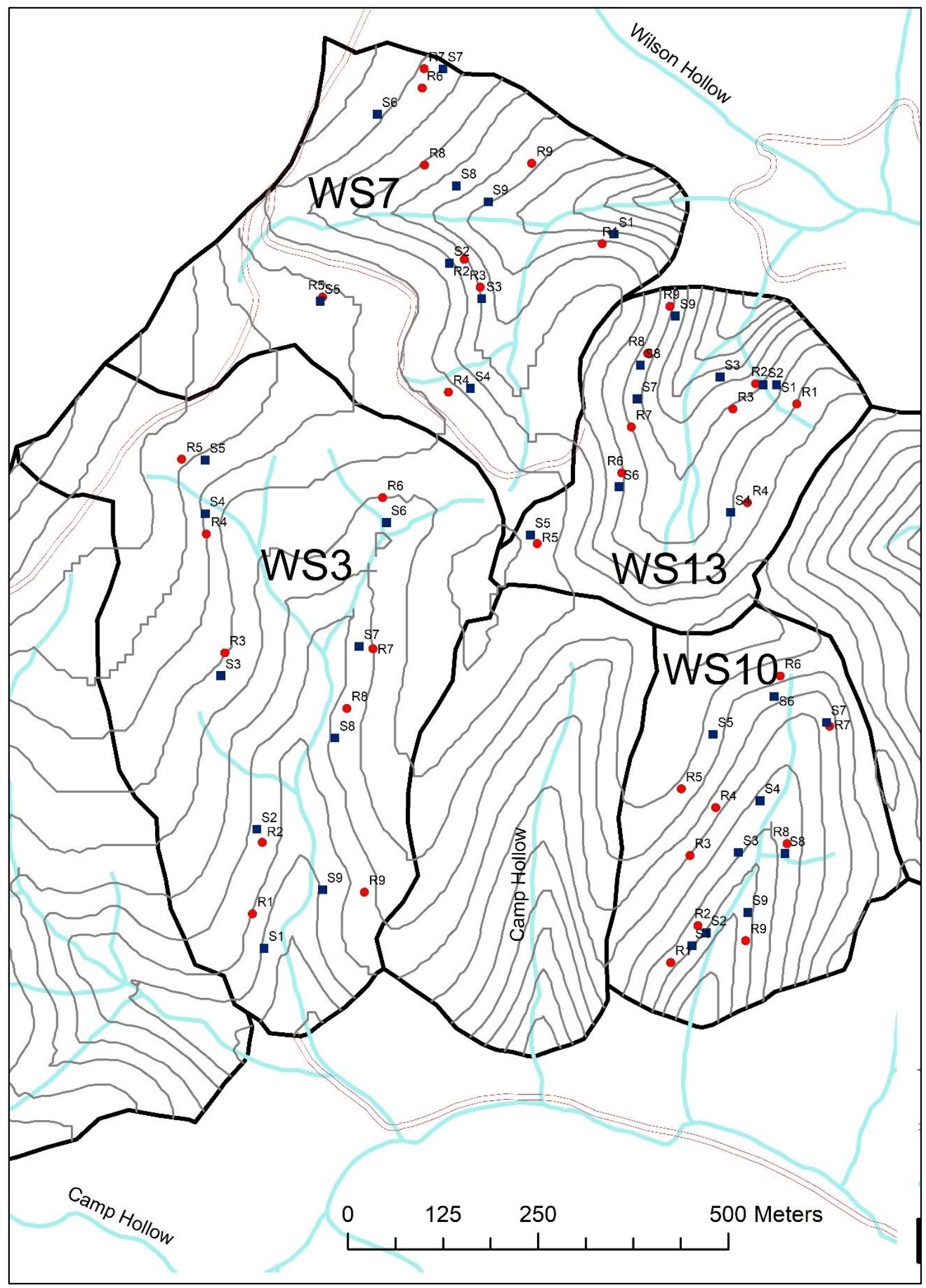

Figure A1. Location of sites 1-9 within each watershed. Plot center trees are marked with a square for sugar maple and a circle for red maple. 